\title{
Oak Ridge National Laboratory Shutdown Dose Rate Code Suite
}

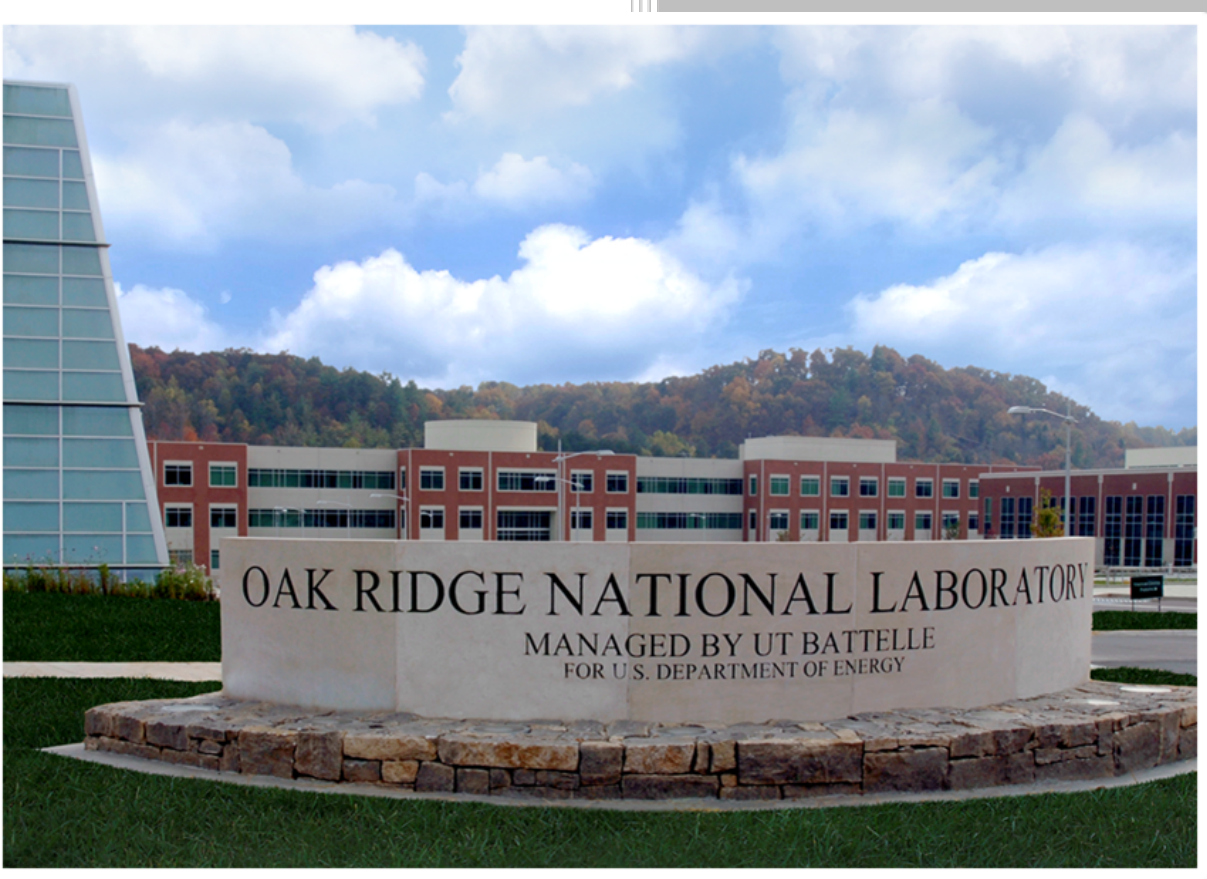

Approved for public release.

Distribution is unlimited.

Arzu Alpan

September 2020 


\title{
DOCUMENT AVAILABILITY
}

Reports produced after January 1, 1996, are generally available free via US Department of Energy (DOE) SciTech Connect.

Website www.osti.gov

Reports produced before January 1, 1996, may be purchased by members of the public from the following source:

\author{
National Technical Information Service \\ 5285 Port Royal Road \\ Springfield, VA 22161 \\ Telephone 703-605-6000 (1-800-553-6847) \\ TDD 703-487-4639 \\ Fax 703-605-6900 \\ E-mail info@ntis.gov \\ Website http://classic.ntis.gov/
}

Reports are available to DOE employees, DOE contractors, Energy Technology Data Exchange representatives, and International Nuclear Information System representatives from the following source:

Office of Scientific and Technical Information

PO Box 62

Oak Ridge, TN 37831

Telephone 865-576-8401

Fax 865-576-5728

E-mail reports@osti.gov

Website http://www.osti.gov/contact.html

This report was prepared as an account of work sponsored by an agency of the United States Government. Neither the United States Government nor any agency thereof, nor any of their employees, makes any warranty, express or implied, or assumes any legal liability or responsibility for the accuracy, completeness, or usefulness of any information, apparatus, product, or process disclosed, or represents that its use would not infringe privately owned rights. Reference herein to any specific commercial product, process, or service by trade name, trademark, manufacturer, or otherwise, does not necessarily constitute or imply its endorsement, recommendation, or favoring by the United States Government or any agency thereof. The views and opinions of authors expressed herein do not necessarily state or reflect those of the United States Government or any agency thereof. 
Reactor and Nuclear Systems Division

\title{
OAK RIDGE NATIONAL LABORATORY SHUTDOWN DOSE RATE CODE SUITE
}

\author{
Arzu Alpan
}

Date Published: September 2020

Prepared by

OAK RIDGE NATIONAL LABORATORY

Oak Ridge, TN 37831-6283

managed by

UT-BATTELLE, LLC

for the

US DEPARTMENT OF ENERGY

under contract DE-AC05-00OR22725 



\section{CONTENTS}

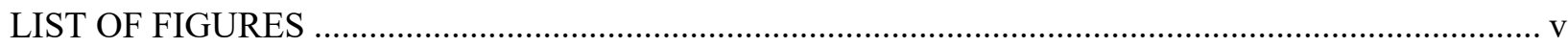

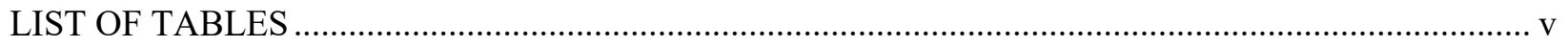

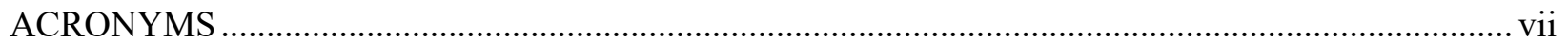

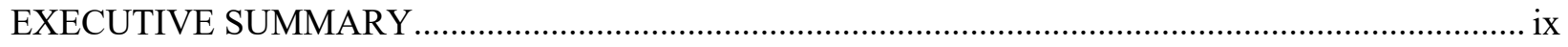

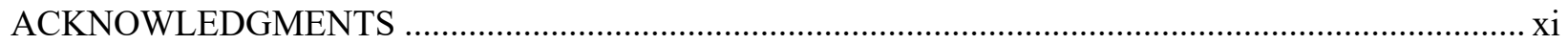

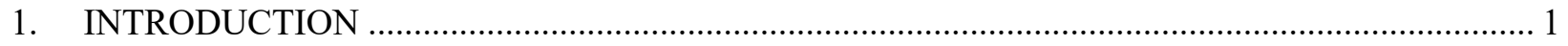

2. APPLICATION OF THE MS-CADIS METHOD TO THE INTERNATIONAL

THERMONUCLEAR EXPERIMENTAL REACTOR SHUTDOWN DOSE RATE BENCHMARK

PROBLEM .......................................................................................................... 5

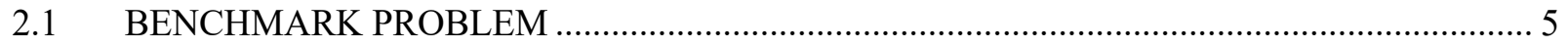

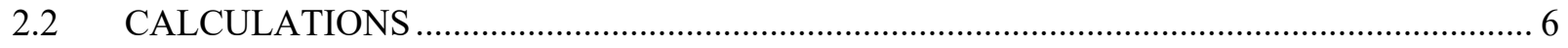

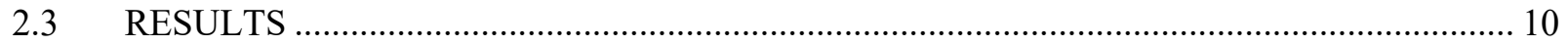

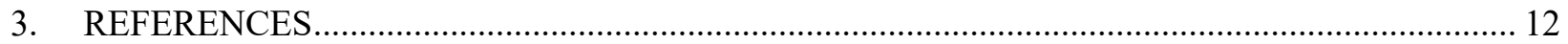

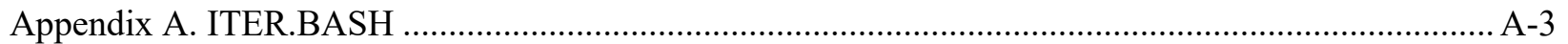

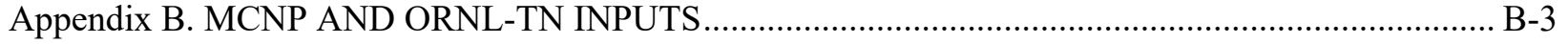





\section{LIST OF FIGURES}

Figure 1. ORNL shutdown dose rate code suite flowchart. .................................................................. 2

Figure 2. ITER shutdown dose rate benchmark geometry................................................................... 5

\section{LIST OF TABLES}

Table 1. ITER shutdown dose rate benchmark irradiation history ...................................................... 6

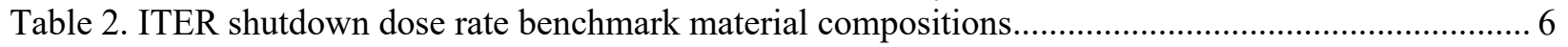

Table 3. Isotope abundances from the IAEA live chart of nuclides .................................................... 7

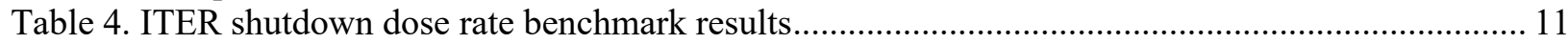





\section{ACRONYMS}

$\begin{array}{ll}\text { ADVANTG } & \text { Automated Variance Reduction Generator } \\ \text { ANS } & \text { American Nuclear Society } \\ \text { ANSI } & \text { American National Standards Institute } \\ \text { CADES } & \text { Compute and Data Environment for Science } \\ \text { CPU } & \text { central processing unit } \\ \text { FENDL } & \text { Fusion Evaluated Nuclear Data Library } \\ \text { hdf5 } & \text { Hierarchical Data Format version 5 } \\ \text { IAEA } & \text { International Atomic Energy Agency } \\ \text { ITER } & \text { International Thermonuclear Experimental Reactor } \\ \text { MCNP } & \text { Monte Carlo N-Particle } \\ \text { MS-CADIS } & \text { Multi-Step Consistent Adjoint Driven Importance Sampling } \\ \text { NAGSS } & \text { Neutron Activation Gamma Source Sampler } \\ \text { ORIGEN } & \text { Oak Ridge Isotope Generator } \\ \text { ORNL } & \text { Oak Ridge National Laboratory } \\ \text { R2S } & \text { rigorous two-step } \\ \text { SCALE } & \text { Standardized Computer Analyses for Licensing Evaluation } \\ \text { SDDR } & \text { shutdown dose rate } \\ \text { TENDL } & \text { TALYS-based Evaluated Nuclear Data Library } \\ \text { TN } & \text { Transformative Neutronics } \\ \text { US } & \text { United States }\end{array}$





\section{EXECUTIVE SUMMARY}

The Oak Ridge National Laboratory (ORNL) shutdown dose rate (SDDR) code suite calculates gamma dose rates at a location of interest due to activation of materials. The code suite is based on the rigorous two-step (R2S) method that involves two radiation transport calculations: (1) neutron radiation transport to determine neutron fluxes in the material for which activation calculations will be performed and (2) gamma radiation transport to determine dose rates at a location of interest, due to material activation. The ORNL SDDR code suite is used to determine an importance function that characterizes the neutron's importance to the final SDDR when the Monte Carlo radiation transport method is used.

This report demonstrates how the ORNL SDDR code suite is implemented through the following codes: Monte Carlo N-Particle (MCNP) code Version 5-1.60, Oak Ridge Isotope Generator (ORIGEN), MSX suite of utilities, Neutron Activation Gamma Source Sampler (NAGSS), and Automated Variance Reduction Generator (ADVANTG). For this demonstration, the International Thermonuclear Experimental Reactor (ITER) SDDR benchmark problem is used and the dose rate result is compared to previously published work. 



\section{ACKNOWLEDGMENTS}

The author would like to thank Katherine E. Royston for her assistance in using the computer script for this work and Georgeta Radulescu and Charles R. Daily for reviewing this report. Support for this work was provided by the United States (US) Nuclear Regulatory Commission, Office of Nuclear Regulatory Research. This research used the resources of the Compute and Data Environment for Science (CADES) at the Oak Ridge National Laboratory (ORNL), which is supported by the Office of Science of the US Department of Energy under contract DE-AC05-00OR22725. 



\section{INTRODUCTION}

Shutdown dose rate (SDDR) calculations involve the determination of gammas emitted due to the decay of radionuclides in materials that become activated from operation of a nuclear system. The Oak Ridge National Laboratory (ORNL) SDDR code suite [1,2] is based on the rigorous two-step (R2S) method. The $\mathrm{R} 2 \mathrm{~S}$ method involves the following steps:

1. Performing a neutron transport calculation to generate a space- and energy-dependent neutron flux solution

2. Performing an activation calculation to generate a decay gamma source distribution in activated materials

3. Performing a gamma transport calculation using the decay gamma source distribution in Step 2 as the source, to calculate the SDDR

In the ORNL SDDR code suite, the Monte Carlo N-Particle (MCNP) code Version 5-1.60 [3] is used for neutron and gamma transport calculations with the ORNL-Transformative Neutronics (ORNL-TN) Version 1.0.0 patch [5]. The Oak Ridge Isotope Generator (ORIGEN) in the Standardized Computer Analyses for Licensing Evaluation (SCALE) code package Version 6.3.pre-b13 (branch 'cades-update' \#2315dc0b on 2020AUG28) is used in activation calculations [4]. MSX Version 1.1.0, Neutron Activation Gamma Source Sampler (NAGSS) Version 1.1.0, Automated Variance Reduction Generator (ADVANTG) code Version 3.2.0 [5], and Denovo from SCALE Version 6.3.pre-b13 (branch 'cadesupdate' \#2315dc0b on 2020AUG28) were used to accelerate the SDDR calculation.

In the R2S method, determining variance reduction parameters for the neutron transport calculation may be challenging because an importance function that characterizes the neutron importance to the final SDDR is needed. The Multi-Step Consistent Adjoint Driven Importance Sampling (MS-CADIS) method $[1,2]$ overcomes this challenge. In the MS-CADIS method, the adjoint neutron source to be used in generating weight windows for the neutron transport calculation is computed by multiplying the gamma adjoint function with the transpose of transition matrices. The transition matrices describe the nuclear transmutations, burnup by neutron irradiation, and decay of radioactive nuclides using the irradiation history of a system $[1,2]$.

The flowchart of the MS-CADIS method is given in Figure 1. Note that boxes that indicate "MCNP5" in the flowchart actually use the ORNL-TN upgrade to MCNP Version 5 [5]. Using MCNP5 with the ORNL-TN patch improves the scalability and performance of the MCNP5 code. ORNL-TN implements a shared memory mesh tally option for multithreaded simulations that reduces tally memory usage by a factor equal to the number of central processing unit (CPU) cores used. Also, the patch implements an option to write mesh tally output in Hierarchical Data Format version 5 (hdf5) binary format, which significantly improves input/output performance for large mesh tallies and reduces the size of output files compared to those output by MCNP. 


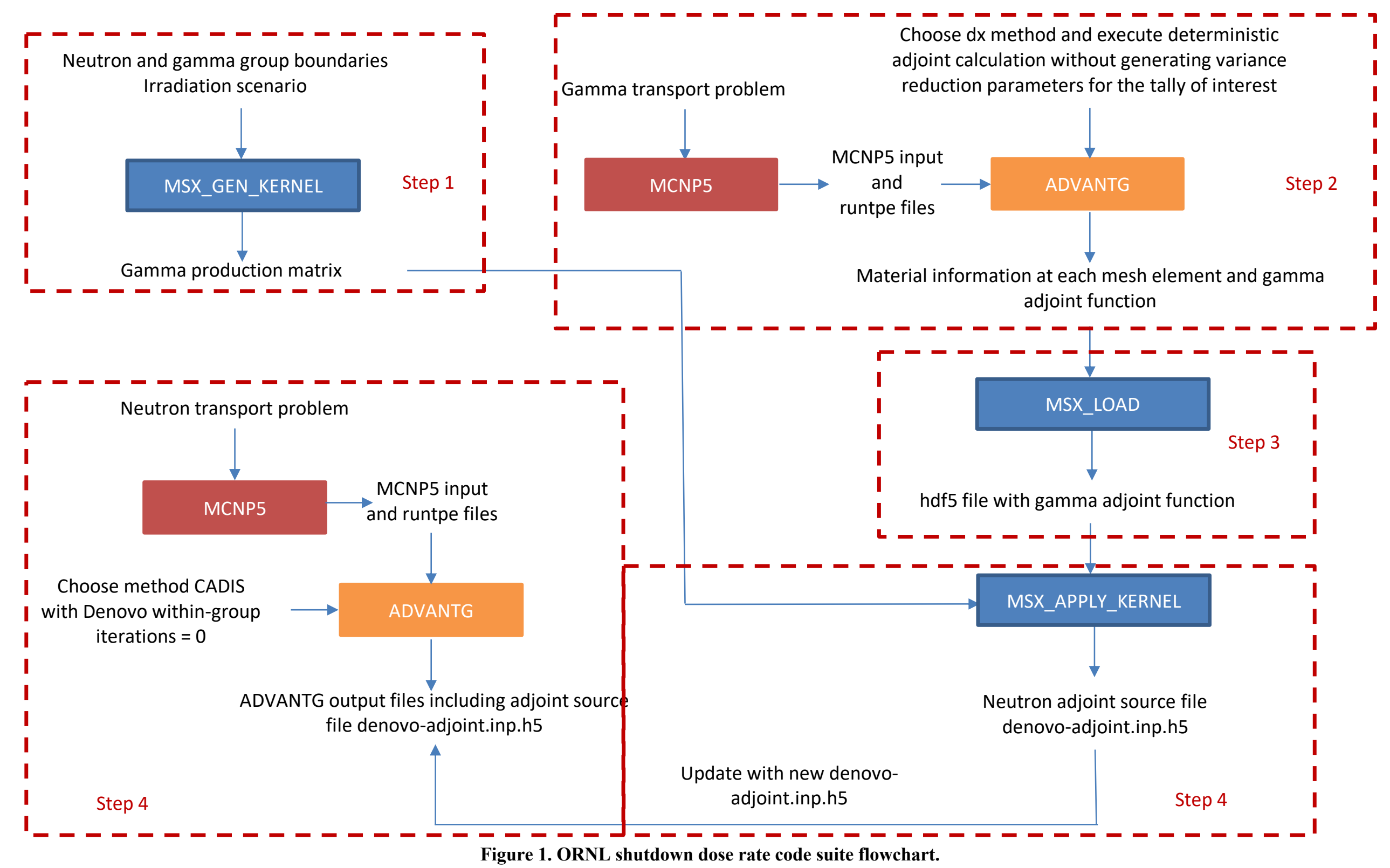




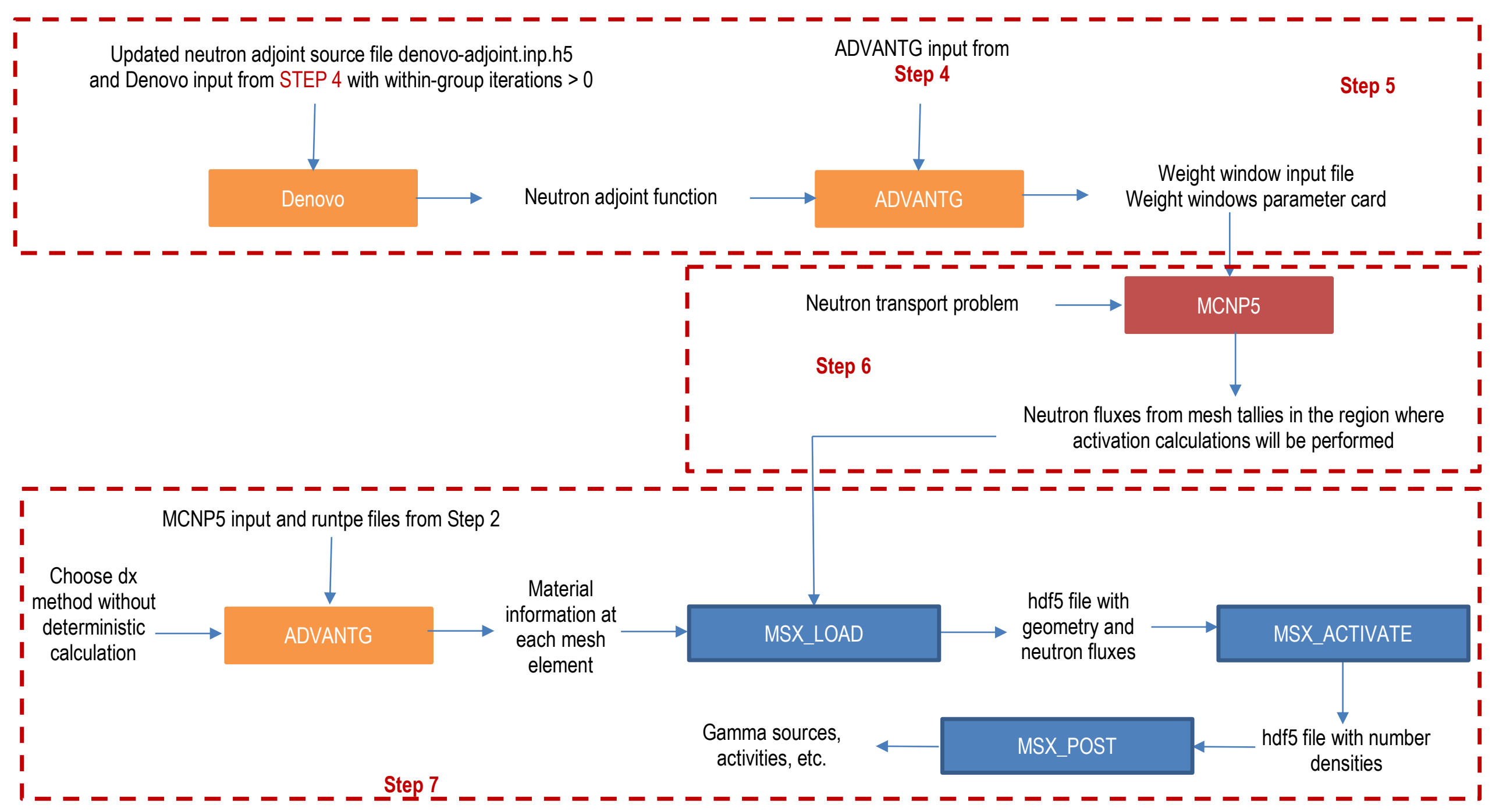

Figure 1. ORNL shutdown dose rate code suite flowchart (continued). 


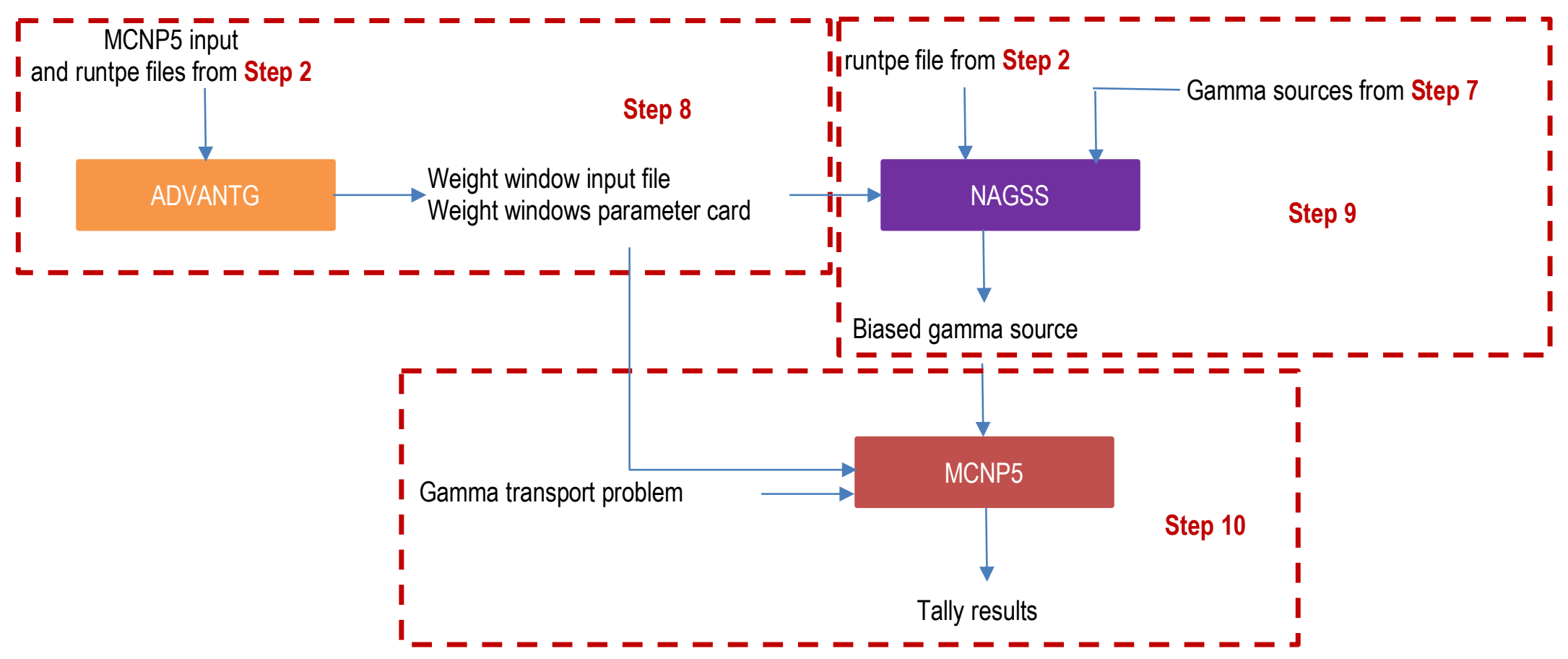

Figure 1. ORNL shutdown dose rate code suite flowchart (continued). 


\section{APPLICATION OF THE MS-CADIS METHOD TO THE INTERNATIONAL THERMONUCLEAR EXPERIMENTAL REACTOR SHUTDOWN DOSE RATE BENCHMARK PROBLEM}

The ITER SDDR benchmark was selected to demonstrate the application of the MS-CADIS R2S method. This benchmark, which simulates an ITER upper port plug, has been presented in several papers $[1,2,6,7,8,9]$.

\subsection{BENCHMARK PROBLEM}

The geometry of the benchmark problem is shown in Figure 3 of [1], Figure 2 of [2], Figure 2 of [6], Figure 10 of [7], Figure 7 of [8], Figure 1 of [9] and Figure 2 of this report. The geometry includes a steel cylindrical ring with an outer radius of $100 \mathrm{~cm}$, an inner radius of $50 \mathrm{~cm}$, and a length of $550 \mathrm{~cm}[2,7]$. There is a $15 \mathrm{~cm}$ thick steel plate at one end of this cylindrical ring and tally cells are placed $30 \mathrm{~cm}$ away from that steel plate. At the other end, inside the steel cylindrical ring, there is a steel and water cylindrical ring with an inner radius of $7.5 \mathrm{~cm}$, an outer radius of $48 \mathrm{~cm}$, and a length of $210 \mathrm{~cm}$. There is a $2 \mathrm{~cm}$ gap between the steel cylindrical ring and the steel/water cylindrical ring. There is also a $2 \mathrm{~cm}$ gap between the top and bottom of the steel plate and the steel cylindrical ring.

There is an isotropic neutron source cell that is $10 \mathrm{~cm}$ thick and $100 \mathrm{~cm}$ away from the end that includes the steel/water region, as shown in Figure 2. This source emits $14 \mathrm{MeV}$ neutrons, which is uniformly distributed within the source cell. The irradiation history is given in Table $1[1,2,6,7]$. The steel and steel/water material compositions are given in Table 2 [6].

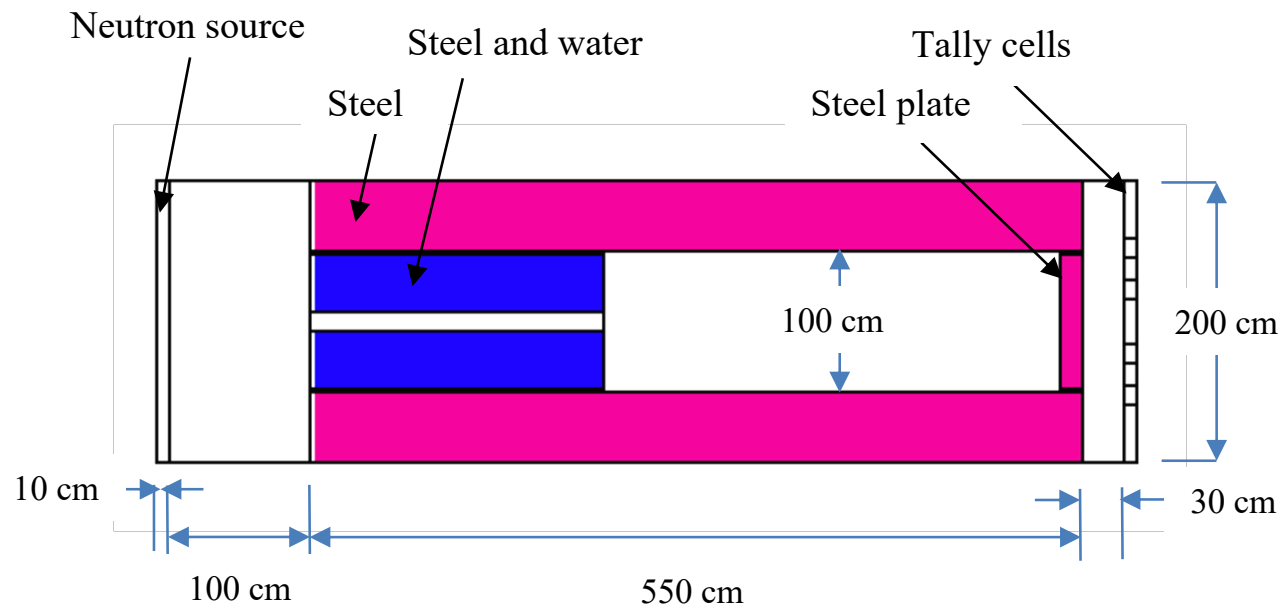

Figure 2. ITER shutdown dose rate benchmark geometry. 
Table 1. ITER shutdown dose rate benchmark irradiation history

\begin{tabular}{lcc}
\hline Neutron source strength $(\mathbf{n} / \mathbf{s})$ & Duration & Repetition \\
\hline $1.0714 \mathrm{E}+17$ & $2 \mathrm{y}$ & Once \\
\hline $8.25 \mathrm{E}+17$ & $10 \mathrm{y}$ & Once \\
\hline 0 & $0.667 \mathrm{y}$ & Once \\
\hline $1.6607 \mathrm{E}+18$ & $1.33 \mathrm{y}$ & Once \\
\hline 0 & $3,920 \mathrm{~s}$ & \\
\hline $2.0 \mathrm{E}+19$ & $400 \mathrm{~s}$ & 17 times \\
\hline 0 & $3,920 \mathrm{~s}$ & \\
\hline $2.8 \mathrm{E}+19$ & $400 \mathrm{~s}$ & 4 times \\
\hline
\end{tabular}

Table 2. ITER shutdown dose rate benchmark material compositions

\begin{tabular}{lcclcc}
\hline \multirow{2}{*}{ Element } & \multicolumn{2}{c}{ Atom fractions } & \multirow{2}{*}{ Element } & \multicolumn{2}{c}{ Atom fractions } \\
\cline { 2 - 3 } & Steel and water & Steel & & Steel and water & Steel \\
\hline $\mathrm{H}$ & $1.46 \mathrm{E}-01$ & - & $\mathrm{Mn}$ & $1.42 \mathrm{E}-02$ & $1.82 \mathrm{E}-02$ \\
\hline $\mathrm{B}$ & $4.02 \mathrm{E}-05$ & $5.14 \mathrm{E}-05$ & $\mathrm{Fe}$ & $5.03 \mathrm{E}-01$ & $6.44 \mathrm{E}-01$ \\
$\mathrm{C}$ & $8.14 \mathrm{E}-04$ & $1.04 \mathrm{E}-03$ & $\mathrm{Co}$ & $3.68 \mathrm{E}-04$ & $4.71 \mathrm{E}-04$ \\
\hline $\mathrm{N}$ & $2.17 \mathrm{E}-03$ & $2.78 \mathrm{E}-03$ & $\mathrm{Ni}$ & $9.06 \mathrm{E}-02$ & $1.16 \mathrm{E}-01$ \\
\hline $\mathrm{O}$ & $7.29 \mathrm{E}-02$ & $6.95 \mathrm{E}-05$ & $\mathrm{Cu}$ & $2.05 \mathrm{E}-03$ & $2.62 \mathrm{E}-03$ \\
\hline $\mathrm{Al}$ & $8.04 \mathrm{E}-04$ & $1.03 \mathrm{E}-03$ & $\mathrm{Zr}$ & $9.52 \mathrm{E}-06$ & $1.22 \mathrm{E}-05$ \\
\hline $\mathrm{Si}$ & $7.73 \mathrm{E}-03$ & $9.89 \mathrm{E}-03$ & $\mathrm{Nb}$ & $4.67 \mathrm{E}-05$ & $5.98 \mathrm{E}-05$ \\
\hline $\mathrm{P}$ & $3.50 \mathrm{E}-04$ & $4.48 \mathrm{E}-04$ & $\mathrm{Mo}$ & $1.13 \mathrm{E}-02$ & $1.45 \mathrm{E}-02$ \\
\hline $\mathrm{S}$ & $1.02 \mathrm{E}-04$ & $1.30 \mathrm{E}-04$ & $\mathrm{Sn}$ & $7.31 \mathrm{E}-06$ & $9.36 \mathrm{E}-06$ \\
\hline $\mathrm{K}$ & $5.55 \mathrm{E}-06$ & $7.10 \mathrm{E}-06$ & $\mathrm{Ta}$ & $2.40 \mathrm{E}-05$ & $3.07 \mathrm{E}-05$ \\
\hline $\mathrm{Ti}$ & $1.36 \mathrm{E}-03$ & $1.74 \mathrm{E}-03$ & $\mathrm{~W}$ & $2.36 \mathrm{E}-06$ & $3.02 \mathrm{E}-06$ \\
\hline $\mathrm{V}$ & $3.41 \mathrm{E}-05$ & $4.36 \mathrm{E}-05$ & $\mathrm{~Pb}$ & $1.68 \mathrm{E}-06$ & $2.14 \mathrm{E}-06$ \\
\hline $\mathrm{Cr}$ & $1.46 \mathrm{E}-01$ & $1.87 \mathrm{E}-01$ & $\mathrm{Bi}$ & $1.66 \mathrm{E}-06$ & $2.13 \mathrm{E}-06$ \\
\hline
\end{tabular}

\subsection{CALCULATIONS}

The MCNP neutron transport calculations were based on Fusion Evaluated Nuclear Data Library (FENDL) 2.1 or FENDL 3.1b. Note that due to a processing error in the ${ }^{39} \mathrm{~K}$ data in the FENDL $3.1 \mathrm{~b}$ distribution, this isotope was processed at ORNL with the TALYS-based Evaluated Nuclear Data Library (TENDL) 2012 data. The MCNP gamma transport calculations were based on MCPLIB04 [3].

Isotope abundances of each element used in the material card in the MCNP inputs were taken from the International Atomic Energy Agency (IAEA) Live Chart of Nuclides [10]. These data are provided in Table 3. 
Table 3. Isotope abundances from the IAEA live chart of nuclides

\begin{tabular}{|c|c|c|c|c|c|c|c|c|}
\hline Element & Isotope & $\begin{array}{c}\text { Abundance } \\
(\%)\end{array}$ & Element & Isotope & $\begin{array}{c}\text { Abundance } \\
(\%)\end{array}$ & Element & Isotope & $\begin{array}{c}\text { Abundance } \\
(\%)\end{array}$ \\
\hline \multirow{2}{*}{$\mathrm{H}$} & ${ }^{1} \mathrm{H}-1$ & 99.9885 & $\mathrm{Mn}$ & ${ }^{55} \mathrm{Mn}$ & 100 & \multirow{5}{*}{ Sn } & ${ }^{118} \mathrm{Sn}$ & 24.22 \\
\hline & ${ }^{2} \mathrm{H}$ & 0.0115 & \multirow{4}{*}{$\mathrm{Fe}$} & ${ }^{54} \mathrm{Fe}$ & 5.845 & & ${ }^{119} \mathrm{Sn}$ & 8.59 \\
\hline \multirow{2}{*}{ B } & ${ }^{10} \mathrm{~B}$ & 19.9 & & ${ }^{56} \mathrm{Fe}$ & 91.754 & & ${ }^{120} \mathrm{Sn}$ & 32.58 \\
\hline & ${ }^{11} \mathrm{~B}$ & 80.1 & & ${ }^{57} \mathrm{Fe}$ & 2.119 & & ${ }^{122} \mathrm{Sn}$ & 4.63 \\
\hline $\mathrm{C}$ & ${ }^{12} \mathrm{C}$ & 100 & & ${ }^{58} \mathrm{Fe}$ & 0.282 & & ${ }^{124} \mathrm{Sn}$ & 5.79 \\
\hline \multirow{2}{*}{$\mathrm{N}$} & ${ }^{14} \mathrm{~N}$ & 99.636 & Co & ${ }^{59} \mathrm{Co}$ & 100 & $\mathrm{Ta}$ & ${ }^{181} \mathrm{Ta}$ & 100 \\
\hline & ${ }^{15} \mathrm{~N}$ & 0.364 & & ${ }^{58} \mathrm{Ni}$ & 68.077 & \multirow{5}{*}{ W } & ${ }^{180} \mathrm{~W}$ & 0.12 \\
\hline $\mathrm{O}$ & ${ }^{16} \mathrm{O}$ & 100 & & ${ }^{60} \mathrm{Ni}$ & 26.223 & & ${ }^{182} \mathrm{~W}$ & 26.5 \\
\hline $\mathrm{Al}$ & ${ }^{27} \mathrm{Al}$ & 100 & $\mathrm{Ni}$ & ${ }^{61} \mathrm{Ni}$ & 1.1399 & & ${ }^{183} \mathrm{~W}$ & 14.31 \\
\hline \multirow{3}{*}{$\mathrm{Si}$} & ${ }^{14} \mathrm{Si}$ & 92.223 & & ${ }^{62} \mathrm{Ni}$ & 3.6346 & & ${ }^{184} \mathrm{~W}$ & 30.64 \\
\hline & ${ }^{15} \mathrm{Si}$ & 4.685 & & ${ }^{64} \mathrm{Ni}$ & 0.9255 & & ${ }^{186} \mathrm{~W}$ & 28.43 \\
\hline & ${ }^{16} \mathrm{Si}$ & 3.092 & $\mathrm{Cu}$ & ${ }^{63} \mathrm{Cu}$ & 69.15 & \multirow{4}{*}{$\mathrm{Pb}$} & ${ }^{204} \mathrm{~Pb}$ & 1.4 \\
\hline $\mathrm{P}$ & ${ }^{31} \mathrm{P}$ & 100 & & ${ }^{65} \mathrm{Cu}$ & 30.85 & & ${ }^{206} \mathrm{~Pb}$ & 24.1 \\
\hline \multirow{4}{*}{$\mathrm{S}$} & ${ }^{32} \mathrm{~S}$ & 94.99 & \multirow{5}{*}{$\mathrm{Zr}$} & ${ }^{90} \mathrm{Zr}$ & 51.45 & & ${ }^{207} \mathrm{~Pb}$ & 22.1 \\
\hline & ${ }^{33} \mathrm{~S}$ & 0.75 & & ${ }^{91} \mathrm{Zr}$ & 11.22 & & ${ }^{208} \mathrm{~Pb}$ & 52.4 \\
\hline & ${ }^{34} \mathrm{~S}$ & 4.25 & & ${ }^{92} \mathrm{Zr}$ & 17.15 & $\mathrm{Bi}$ & ${ }^{209} \mathrm{Bi}$ & 100 \\
\hline & ${ }^{36} \mathrm{~S}$ & 0.01 & & ${ }^{94} \mathrm{Zr}$ & 17.38 & & & \\
\hline \multirow{3}{*}{ K } & ${ }^{39} \mathrm{~K}$ & 93.2581 & & ${ }^{96} \mathrm{Zr}$ & 2.8 & & & \\
\hline & ${ }^{40} \mathrm{~K}$ & 0.0117 & $\mathrm{Nb}$ & ${ }^{93} \mathrm{Nb}$ & 100 & & & \\
\hline & ${ }^{41} \mathrm{~K}$ & 6.7302 & \multirow{7}{*}{ Mo } & ${ }^{92} \mathrm{Mo}$ & 14.53 & & & \\
\hline \multirow{5}{*}{$\mathrm{Ti}$} & ${ }^{46} \mathrm{Ti}$ & 8.25 & & ${ }^{94} \mathrm{Mo}$ & 9.15 & & & \\
\hline & ${ }^{47} \mathrm{Ti}$ & 7.44 & & ${ }^{95} \mathrm{Mo}$ & 15.84 & & & \\
\hline & ${ }^{48} \mathrm{Ti}$ & 73.72 & & ${ }^{96} \mathrm{Mo}$ & 16.67 & & & \\
\hline & ${ }^{49} \mathrm{Ti}$ & 5.41 & & ${ }^{97} \mathrm{Mo}$ & 9.6 & & & \\
\hline & ${ }^{50} \mathrm{Ti}$ & 5.18 & & ${ }^{98} \mathrm{Mo}$ & 24.39 & & & \\
\hline \multirow{2}{*}{ V } & ${ }^{50} \mathrm{~V}$ & 0.25 & & ${ }^{100} \mathrm{Mo}$ & 9.82 & & & \\
\hline & ${ }^{51} \mathrm{~V}$ & 99.75 & \multirow{5}{*}{ Sn } & ${ }^{112} \mathrm{Sn}$ & 0.97 & & & \\
\hline \multirow{4}{*}{$\mathrm{Cr}$} & ${ }^{50} \mathrm{Cr}$ & 4.345 & & ${ }^{114} \mathrm{Sn}$ & 0.66 & & & \\
\hline & ${ }^{52} \mathrm{Cr}$ & 83.789 & & ${ }^{115} \mathrm{Sn}$ & 0.34 & & & \\
\hline & ${ }^{53} \mathrm{Cr}$ & 9.501 & & ${ }^{116} \mathrm{Sn}$ & 14.54 & & & \\
\hline & ${ }^{54} \mathrm{Cr}$ & 2.365 & & ${ }^{117} \mathrm{Sn}$ & 7.68 & & & \\
\hline
\end{tabular}

The multigroup structures that were used for the ITER SDDR benchmark were as follows:

1. Coupled 46-neutron- and 21-gamma-group library. The group boundaries consist of a subset of the VITAMIN-J library [11,12]. This group structure is used in MSX_GEN_KERNEL in Step 1 and ADVANTG to generate a gamma adjoint function in Step 2, a neutron adjoint source in Step 4, neutron weight windows in Step 5, and gamma weight windows in Step 8.

2. 175-neutron-group VITAMIN-J structure. This group structure is used for mesh tallies in the MCNP input of Step 6. 
3. 54-gamma-group structure. This group structure is a modified version of the 42-gamma-group VITAMIN-J structure. The development of the 54-gamma groups was needed to effectively capture the important gamma emission lines. If a decay energy lies at the edge of an energy group, then the decay energy is shifted up or down. If the group is wide to accommodate an important decay energy, then this can also affect the solution. Therefore, the 54-gamma-group structure has finely spaced groups near the important gamma emission lines. This group structure is used in MSX_POST in Step 7.

The American National Standards Institute (ANSI)/American Nuclear Society (ANS)-6.1.1 [13] flux-todose rate conversion factors were used to calculate responses at the SDDR location in the ITER benchmark.

The script that was used to generate SDDRs for the ITER benchmark was developed for scalable highperformance computing using Compute and Data Environment for Science (CADES) at ORNL . A simplified version of this script that is not CADES-specific - iter.bash - is given in Appendix A. The MCNP input decks used in the script - mcnp_inp_G, monp_inp_G_adv, menp_inp_N, monp_inp_N_adv, config (for ORNL-TN), and config_G (for ORNL-TN) - are given in Appendix B. ${ }^{\bar{*}}$ This script was divided into ten steps as outlined in Figure 1. The ten steps are described below.

\section{Step 1}

Gamma sources from nuclide decay are calculated with MSX_GEN_KERNEL using the 173 nuclides in the FENDL3 library. The multigroup library contains coupled 46-neutron and 21-gamma groups and is based on FENDL-3.1b. The energy group boundaries and irradiation history are given as input.

\section{Step 2}

The MCNP code uses monp_inp_G_adv to calculate a runtpe file to be used in ADVANTG for the benchmark problem. This MCNP input file is for gamma transport. The MCNP material card includes identification numbers of nuclides for neutron interactions from an xsdir file based on FENDL-2.1 (nuclide identification with extension 21c) and FENDL-3.1 (nuclide identification with extension 31c). The atom fractions given in Table 2 were input into the material cards for each nuclide. Isotope abundances of each element were taken from the IAEA Live Chart of Nuclides as given in Table 3. The input gamma source is arbitrary. Tally cells, which are located $30 \mathrm{~cm}$ away from the $15 \mathrm{~cm}$ steel plate and are the locations of interest for the final dose rate calculation, are modified using ANSI/ANS-6.1.1-1977 flux-to-dose-rate conversion factors.

In the ADVANTG input input_photon_adjoint, the dx method is selected to discretize the transport model and execute a deterministic adjoint calculation. The adjoint source corresponds to the cell flux tallies at the final dose rate location as modified by ANSI/ANS-6.1.1-1977 flux-to-dose rate conversion factors. Spatial discretization of the Denovo parallel discrete ordinates solver model includes $5 \mathrm{~cm}$ meshes in the $\mathrm{x}, \mathrm{y}$, and $\mathrm{z}$ directions. The model is executed with $\mathrm{P}_{3}$ order of Legendre expansion and a quadruple range quadrature set with 8 polar directions. The FENDL-3.1b 46-neutron- and 21-gamma-group cross-section library is used.

\footnotetext{
${ }^{*}$ Files are modified versions of those that were generated by Stephen C. Wilson (Los Alamos National Laboratory).
} 


\section{Step 3}

The MSX_LOAD code is executed to load material data (spatial mesh, material composition, material mixing table, and material map) and photon adjoint function from the Step 2 ADVANTG outputs.

\section{Step 4}

The MCNP code uses monp_inp_N_adv to calculate a runtpe file to be used in ADVANTG. This MCNP input file is for neutron transport. The MCNP material card includes identification numbers of nuclides for neutron interactions from an xsdir file based on FENDL-2.1 (nuclide identification with extension 21c) and FENDL-3.1 (nuclide identification with extension 31c). The atom fractions given in Table 2 were input into the material cards for each nuclide. Isotope abundances of each element were taken from the IAEA Live Chart of Nuclides as given in Table 3. The input neutron source is arbitrary. Mesh tallies are set up within the large steel cylinder (outer radius of $100 \mathrm{~cm}$ and length of $550 \mathrm{~cm}$ ), having $\mathrm{x}, \mathrm{y}$, and $\mathrm{z}$ mesh lengths of $5 \mathrm{~cm}$. The 175-neutron-group structure of VITAMIN-J is given in the mesh tally input.

In the ADVANTG input input_advantg_n_v1, the CADIS method is selected, but a deterministic calculation is not executed. The adjoint source corresponds to the mesh tallies within the large cylinder (outer radius of $100 \mathrm{~cm}$ and length of $550 \mathrm{~cm}$ ). Spatial discretization of the Denovo parallel discrete ordinates solver model includes $5 \mathrm{~cm}$ meshes in the $\mathrm{x}, \mathrm{y}$, and $\mathrm{z}$ directions. The model is set up with $\mathrm{P}_{3}$ order of Legendre expansion and a quadruple range quadrature set with 8 polar directions. The FENDL3.1b 46-neutron-, 21-gamma-group cross-section library is specified.

The MSX_APPLY_KERNEL code is executed to calculate the MS-CADIS adjoint neutron source using the outputs of Steps 1 and 3. The same irradiation history in Step 1 is used in MSX_APPLY_KERNEL. The adjoint neutron source file from the ADVANTG run (see previous paragraph) is updated by the new adjoint source generated by MSX_APPLY_KERNEL.

\section{Step 5}

Using the adjoint neutron source in Step 4, the Denovo input from Step 4 is executed by setting the within-group iterations to 100. A neutron adjoint function is generated. Using this adjoint function with the ADVANTG input input_advantg_n_v1, a neutron weight window file and parameter card are generated.

\section{Step 6}

The MCNP input file monp_inp_N is executed with the weight windows generated in Step 5. This MCNP input file is for neutron transport. The MCNP material card includes identification numbers of nuclides for neutron interactions from an xsdir file based on FENDL-2.1 (nuclide identification with extension 21c) and FENDL-3.1 (nuclide identification with extension 31c). The atom fractions given in Table 2 were input into the material cards for each nuclide. Isotope abundances of each element were taken from the IAEA Live Chart of Nuclides as given in Table 3. The source definition is provided as $14 \mathrm{MeV}$ neutrons emitted from the $100 \mathrm{~cm}$ radius $10 \mathrm{~cm}$ height cylinder region shown in Figure $3 \mathrm{of} \mathrm{[1].} \mathrm{Mesh}$ tallies are set up within the large cylinder (outer radius of $100 \mathrm{~cm}$ and length of $550 \mathrm{~cm}$ ) having $\mathrm{x}, \mathrm{y}$, and $\mathrm{z}$ mesh lengths of $5 \mathrm{~cm}$. The 175-neutron-group structure of VITAMIN-J is given in the mesh tally input.

\section{Step 7}

The ADVANTG input input_dx is created that uses the $\mathrm{dx}$ method to discretize the MCNP input from Step 2 (mcnp_inp_G_adv) without executing a deterministic calculation. In the ADVANTG input, the $\mathrm{x}$, 
$\mathrm{y}$, and $\mathrm{z}$ dimensions of the benchmark problem are discretized into $5 \mathrm{~cm}$ meshes. The VITAMIN-J library with 175 neutron and 42 gamma groups is specified. Spatial mesh, material compositions, the material mixing table, and the material map are loaded from the ADVANTG output, as well as the mesh tally file generated in Step 6, using the code MSX_LOAD. The output file msx_activate_NAGSS.h5 is generated by MSX_LOAD. This output file is used as input to MSX_ACTIVATE to perform activation calculations in each mesh voxel and generate nuclide number densities. The input for MSX_ACTIVATE, input_msx_activate_NAGSS, includes the same irradiation history specified in Step 1. The number densities generated by MSX_ACTIVATE are used by MSX_POST to generate problem-dependent gamma sources and activities in an hdf5 file in a 54-gamma-group structure.

\section{Step 8}

The MCNP runtpe and input files from Step 2 are used as input to the ADVANTG code. Method CADIS, FENDL 3.1b 46-neutron-, 21-gamma group library, $\mathrm{P}_{3}$ Legendre order of scattering, and quadruple range quadrature set with 8 polar directions are selected in ADVANTG. The MCNP tally number for which variance reduction parameters/adjoint sources are generated corresponds to the location where dose rates are to be calculated. The benchmark problem $\mathrm{x}, \mathrm{y}$, and $\mathrm{z}$ dimensions are discretized into $5 \mathrm{~cm}$ length meshes. A gamma weight windows and parameter card file is produced by ADVANTG.

\section{Step 9}

The NAGSS code is used to generate a biased gamma source for the final gamma transport MCNP calculation. The weight windows file from Step 8, the runtpe file from Step 2, and the gamma sources from Step 7 are used as input.

\section{Step 10}

This step uses the monp_inp_G MCNP input for gamma transport, gamma weight windows and the parameter card from Step 8, and the biased gamma source generated in Step 9 to calculate dose rates at the tally location. The mcnp_inp_G input deck is similar to mcnp_inp_G_adv, with the main difference being the description of the source and use of weight windows / weight window card in monp_inp_G.

\subsection{RESULTS}

In Table 4, the column labeled "Current analysis" provides photon dose rates for the ITER SDDR benchmark calculation. MSX-CADIS was used for the four tally cells shown in Figure 2 with the script and input files provided in Appendices A and B, respectively. Tallies 1, 2, 3, and 4 are tallied over the 0 to $15 \mathrm{~cm}, 15$ to $30 \mathrm{~cm}, 30$ to $45 \mathrm{~cm}$, and 45 to $60 \mathrm{~cm}$ radial extent of the target, respectively [1]. Results from Wilson et al. [1] are also given in Table 4; these results correspond to the case that performed MSX/NAGSS calculations with a cubic mesh having a side length of $5 \mathrm{~cm}$, which is consistent with the current analysis. Additionally, input parameters used by Wilson et al. [1] were utilized here to recalculate photon dose rates in Tallies 1, 2, 3, and 4. These results are listed in the Table 4 column labeled "Current analysis with parameters from Wilson et al. [1]." Relative errors were all less than $1 \%$ for all the tallied photon dose rates included in Table 4. 
Table 4. ITER shutdown dose rate benchmark results

\begin{tabular}{lrcc}
\hline & \multicolumn{3}{c}{ Photon dose rate (Sv/h) } \\
\cline { 2 - 4 } Tally & Current analysis & Wilson et al. [1] & $\begin{array}{c}\text { Current analysis with } \\
\text { parameters from } \\
\text { Wilson et al. [1] }\end{array}$ \\
\hline 1 & $2.659 \mathrm{E}-02$ & $2.086 \mathrm{E}-02$ & $2.104 \mathrm{E}-02$ \\
\hline 2 & $2.252 \mathrm{E}-02$ & $1.765 \mathrm{E}-02$ & $1.778 \mathrm{E}-02$ \\
\hline 3 & $1.722 \mathrm{E}-02$ & $1.350 \mathrm{E}-02$ & $1.358 \mathrm{E}-02$ \\
\hline 4 & $1.236 \mathrm{E}-02$ & $9.708 \mathrm{E}-03$ & $9.747 \mathrm{E}-03$ \\
\hline
\end{tabular}

The photon dose rates under "Current analysis" in Table 4 were calculated by extracting the total biased source from the file nagss_log.out, dividing this value by two, multiplying with each of the tally outputs (1 through 4) below "vals" in the file MCTALMRG, and applying a multiplication factor of 1.0E-05 (to convert $\mathrm{mrem} / \mathrm{h}$ to $\mathrm{Sv} / \mathrm{h}$ ). The division by two is a fixed number that must be applied to the total biased source from the NAGSS execution.

The photon dose rates under "Current analysis with parameters from Wilson et al. [1]" in Table 4 were calculated by extracting the total biased source from the file nagss_log.out, dividing this value by two, multiplying with each of the tally outputs (1 through 4) below "vals" in the file MCTALMRG, and applying a multiplication factor of $1.0 \mathrm{E}-02$ (to convert $\mathrm{rem} / \mathrm{h}$ to $\mathrm{Sv} / \mathrm{h}$ ).

Previously published results for the ITER SDDR benchmark dose rates with MSX-CADIS by Wilson et al. in [1] were reproduced within $1 \%$ relative differences, as given in Table 4 . This small discrepancy is attributed to different computer code versions that might have been used between the two calculations.

A comparison of the dose rate results from the current analysis and those from the analysis of Wilson et al. [1] show relative differences of $\sim 28 \%$. This discrepancy is mainly due to the different flux-to-dose-rate conversion factors used. Other differences that are expected to have a smaller contribution to differences are (1) the format in which the irradiation history was entered (2) the use of different FENDL versions for $\mathrm{S}, \mathrm{K}, \mathrm{V}, \mathrm{Zr}$, and $\mathrm{Sn}$ for neutron interactions in the MCNP material cards, (3) inclusion of ${ }^{204} \mathrm{~Pb}$ in the MCNP material cards in the current analysis, (4) isotopic abundances in determining atomic fractions of nuclides in the MCNP material cards, and (5) quadrature set used in ADVANTG. 


\section{REFERENCES}

1. Stephen C. Wilson, Scott W. Mosher, Katherine E. Royston, Charles R. Daily, and Ahmad M. Ibrahim (2018), "Validation of the MS-CADIS Method for Full-Scale Shutdown Dose Rate Analysis," Fusion Science and Technology 74:4, 288-302, DOI: $\underline{10.1080 / 15361055.2018 .1483687 .}$.

2. Ahmad M. Ibrahim, Douglas E. Peplow, Robert E. Grove, Joshua L. Peterson, and Seth R. Johnson (2015), "The Multi-Step CADIS Method for Shutdown Dose Rate Calculations and Uncertainty Propagation," Nuclear Technology 192:3, 286-298, DOI: 10.13182/NT15-1.

3. Forrest Brown, Brian Kiedrowski, and Jeffrey Bull, MCNP5-1.60 Release Notes, LA-UR-1006235. MCNP6.1/MCNP5/MCNPX: Monte Carlo N-Particle Transport Code System, including MCNP6.1, MCNP5-1.60, MCNPX-2.7.0 and Data Libraries, available from Radiation Safety Information Computational Center (RSICC) as Computer Code Collection (CCC) 810.

4. B.T. Rearden and M.A. Jessee (Eds.), SCALE Code System, ORNL/TM-2005/39, Version 6.2.3, March 2018. SCALE 6.2.3: A Comprehensive Modeling and Simulation Suite for Nuclear Safety Analysis and Design; Includes ORIGEN and AMPX, available from RSICC as CCC-834.

5. S. W. Mosher et al., ADVANTG-An Automated Variance Reduction Parameter Generator, ORNL/TM-2013/416, Rev. 1, August 2015. ADVANTG-3.2.0: Automated Variance Reduction Generator, available from RSICC as CCC-854.

6. Jean-Charles Jaboulay Emeric Brun, François-Xavier Hugot, Tan-Dat Huynh, Fadhel Malouch, Davide Mancusi, and Aime Tsilanizara (2017), Rigorous-Two-Steps Scheme of TRIPOLI-4® Monte Carlo Code Validation for Shutdown Dose Rate Calculation, ICRS-13 \& RPSD-2016, EPJ Web of Conferences 153, 02008, DOI: 10.1051/epjconf/20171530.

7. T. Eade, B. Colling, J. Naish, L.W. Packer and A. Valentine (2020), "Shutdown Dose Rate Benchmarking Using Modern Particle Transport Codes," Nucl. Fusion 60 056024, DOI: 10.1088/1741-4326/ab8181.

8. T. Eade, D. Stonell, and A. Turner (2015), "MCR2S Unstructured Mesh Capabilities for Use in Shutdown Dose Rate Analysis," Fusion Engineering and Design 100 321-333, DOI: 10.1016/j.fusengdes.2015.06.189.

9. Moataz S. Harb, Paul P. H. Wilson, and A. Davis (2017), "The Effect of Constructed Mesh-Based Fluxes on Shutdown Dose Rate Calculations in Fusion Energy Systems," Transactions of the American Nuclear Society 117, Washington, DC, October 29-November 2, 2017.

10. IAEA, Live Chart of Nuclides (Accessed July 20, 2020), available from: https://nds.iaea.org/relnsd/vcharthtml/VChartHTML.html.

11. Groupstructures: Vitamin-J, XMAS, ECCO-33, ECCO2000 Standard Group Structures, available from RSICC as Data Library Collection (DLC) 274, 2016.

12. serpent.vtt.fi, Vitamin-j 175-group structure (Accessed July 27, 2020), available from: http://serpent.vtt.fi/mediawiki/index.php/Vitamin-j_175-group_structure.

13. American National Standards Institute/American Nuclear Society, ANSI/ANS 6.1.1-1977, Neutron and Gamma-Ray Flux-to-Dose Rate Factors, ANS, La Grange Park, IL. 
APPENDIX A. BASH SCRIPT 



\section{APPENDIX A. ITER.BASH}

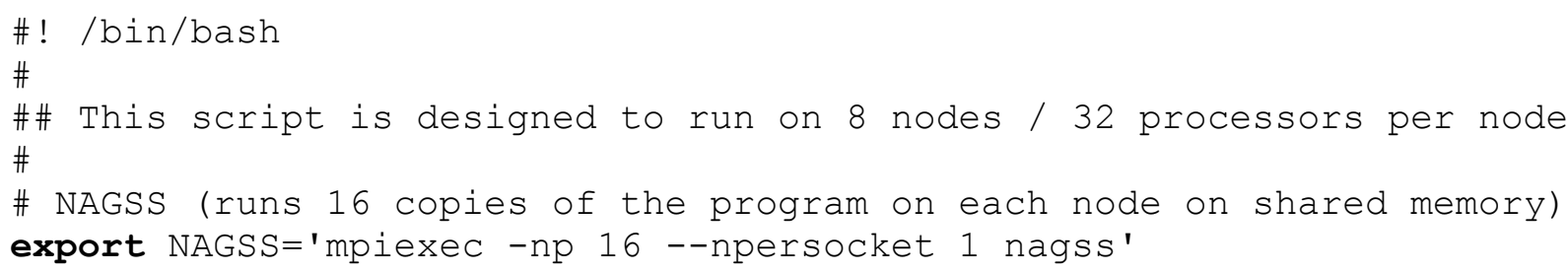




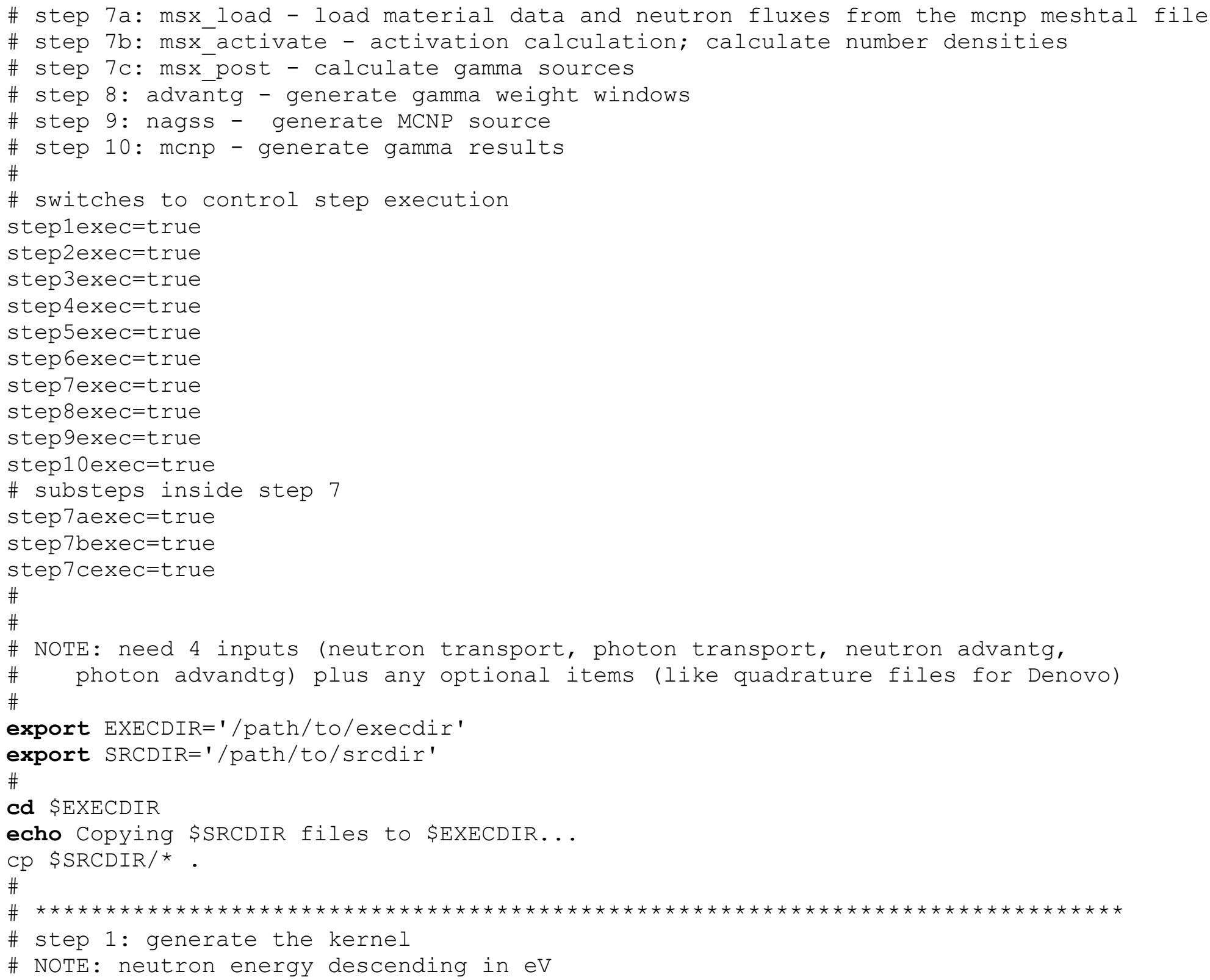


if [ "\$steplexec" = true ]

\section{then}

echo Beginning Step 1

cat $<<$ eof $>$ input_gen_kernel

neutron_group bounds $=(1.4191 \mathrm{E}+07,1.3499 \mathrm{E}+07,1.2214 \mathrm{E}+07,1.1052 \mathrm{E}+07,1.0000 \mathrm{E}+07$, $9.0484 \mathrm{E}+06,8 . \overline{1} 873 \mathrm{E}+06,7.4082 \mathrm{E}+06,6.7032 \mathrm{E}+06,6.0653 \mathrm{E}+06$, $5.4881 \mathrm{E}+06,4.9659 \mathrm{E}+06,4.4933 \mathrm{E}+06,4.0657 \mathrm{E}+06,3.6788 \mathrm{E}+06$, $3.3287 \mathrm{E}+06,3.0119 \mathrm{E}+06,2.7253 \mathrm{E}+06,2.4660 \mathrm{E}+06,1.8268 \mathrm{E}+06$, $1.3534 \mathrm{E}+06,1.0026 \mathrm{E}+06,7.4274 \mathrm{E}+05,5.5023 \mathrm{E}+05,4.0762 \mathrm{E}+05$, $3.0197 \mathrm{E}+05,2.2371 \mathrm{E}+05,1.6573 \mathrm{E}+05,1.2277 \mathrm{E}+05,6.7379 \mathrm{E}+04$, $3.1828 \mathrm{E}+04,1.5034 \mathrm{E}+04,7.1017 \mathrm{E}+03,3.3546 \mathrm{E}+03,1.5846 \mathrm{E}+03$, $7.4852 \mathrm{E}+02,3.5358 \mathrm{E}+02,1.6702 \mathrm{E}+02,7.8893 \mathrm{E}+01,3.7267 \mathrm{E}+01$, $1.7603 \mathrm{E}+01,8.3153 \mathrm{E}+00,3.9279 \mathrm{E}+00,1.8554 \mathrm{E}+00,8.7642 \mathrm{E}-01$, $4.1399 \mathrm{E}-01,1.0000 \mathrm{E}-05)$

gamma group bounds $=(1.4000 \mathrm{E}+01,1.2000 \mathrm{E}+01,1.0000 \mathrm{E}+01,8.0000 \mathrm{E}+00,7.5000 \mathrm{E}+00$, $7.000 \overline{0} \mathrm{E}+00, \overline{6} .5000 \mathrm{E}+00,6.0000 \mathrm{E}+00,5.5000 \mathrm{E}+00,5.0000 \mathrm{E}+00$, $4.5000 \mathrm{E}+00,4.0000 \mathrm{E}+00,3.5000 \mathrm{E}+00,3.0000 \mathrm{E}+00,2.5000 \mathrm{E}+00$, $2.0000 \mathrm{E}+00,1.5000 \mathrm{E}+00,1.0000 \mathrm{E}+00,4.0000 \mathrm{E}-01,2.0000 \mathrm{E}-01$, $1.0000 \mathrm{E}-01,1.0000 \mathrm{E}-02)$

\# ITER Irradiation Scenario

\# NOTE: ITER benchmark indicates 4700 MW pulses at the end

\# of the irradiation scenario.

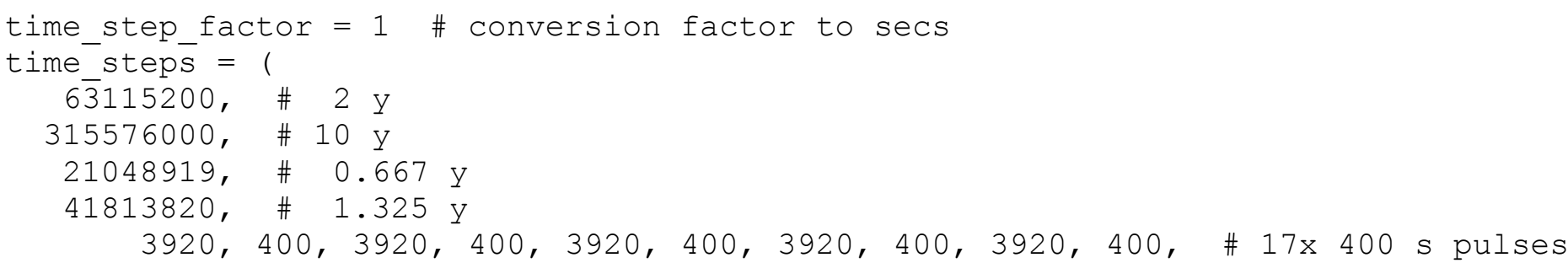




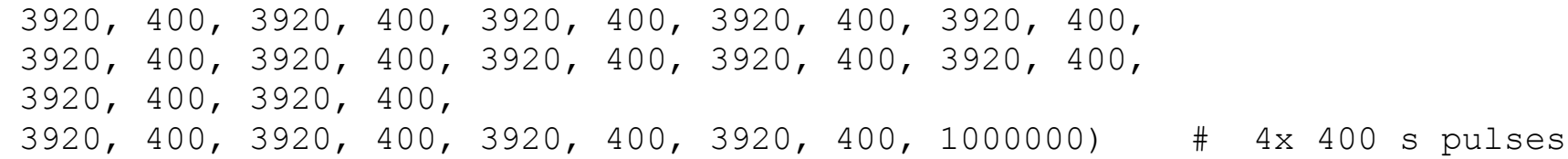

\$MSX_GEN_KERNEL input_gen_kernel

\section{fi}

\# step 2: generate photon adjoint

if [ "\$step2exec" = true ]

then

echo Beginning Step 2

\# Setup and run ADVANTG

cat $<<$ eof2 > input_photon_adjoint

method

$d x$
$d x$ adjoint True
$d x$ forward False 


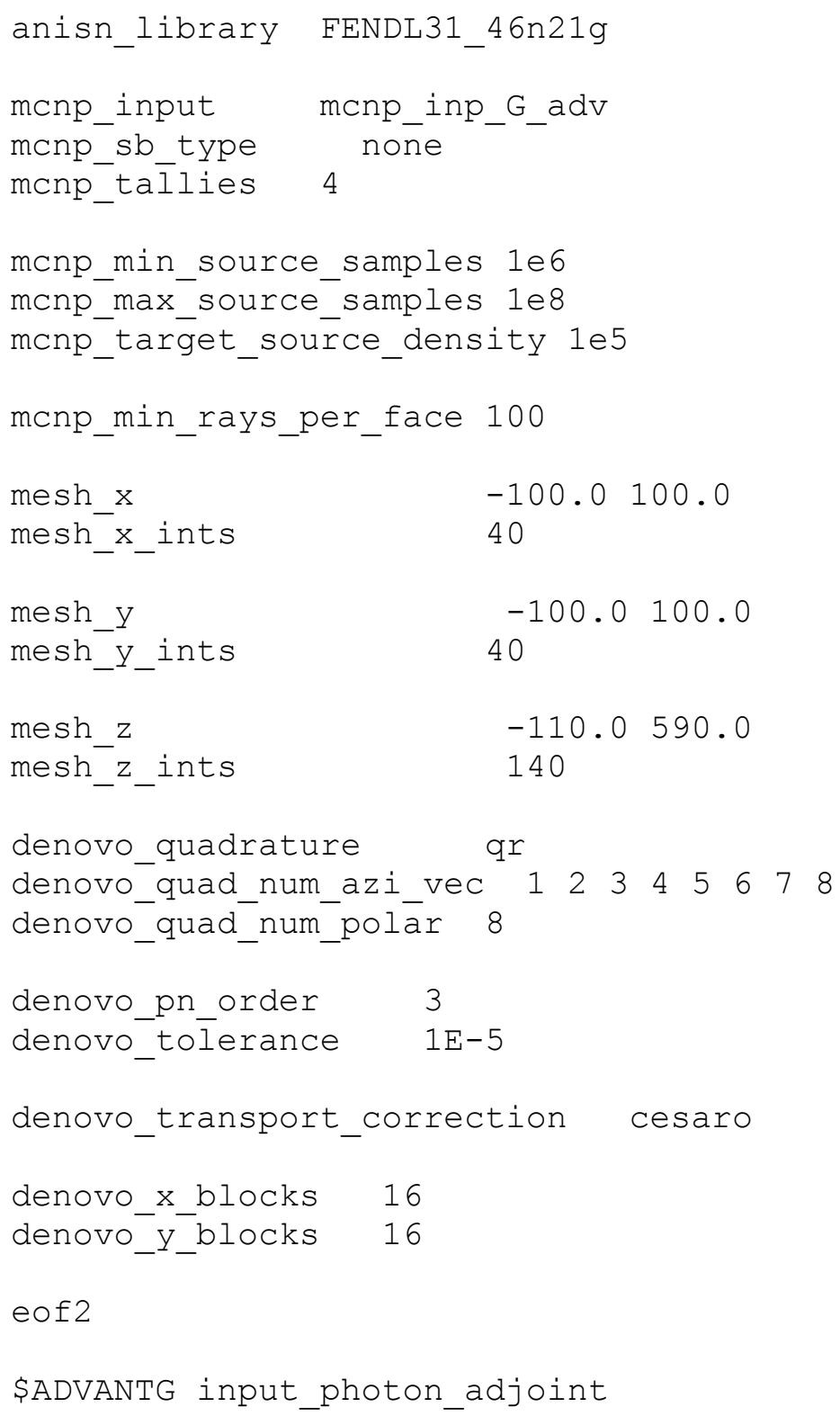


fi

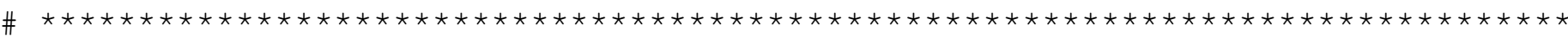

\# step 3: execute msx_load on the ADVANTG output

if [ "\$step3exec" = true ]

then

echo Beginning step 3

cat $<<$ eof3 $>$ input_msx_load_adv.py

SetHDF5File ("msx_adjoint.h5")

SetAdvantgRunDirectory (" . /")

LoadAdvantgMatls ( )

LoadAdvantgFlux ("adj", "p")

eof 3

\$MSX_LOAD input_msx_load_adv.py

fi

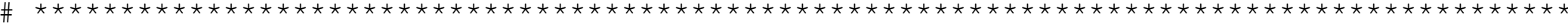

\# step 4: apply kernel to generate adjoint neutron source

if [ "Sstep4exec" = true ]

then

echo Beginning step 4

if [ ! - d advantg_neutron ]

then

fi

mkdir advantg_neutron

cd advantg_neutron

ln $-\mathrm{s} . \mathrm{m}_{\mathrm{m}} \mathrm{np} \mathrm{inp}_{-} \mathrm{N}_{-} \mathrm{adv}$.

ln -s ../config . 


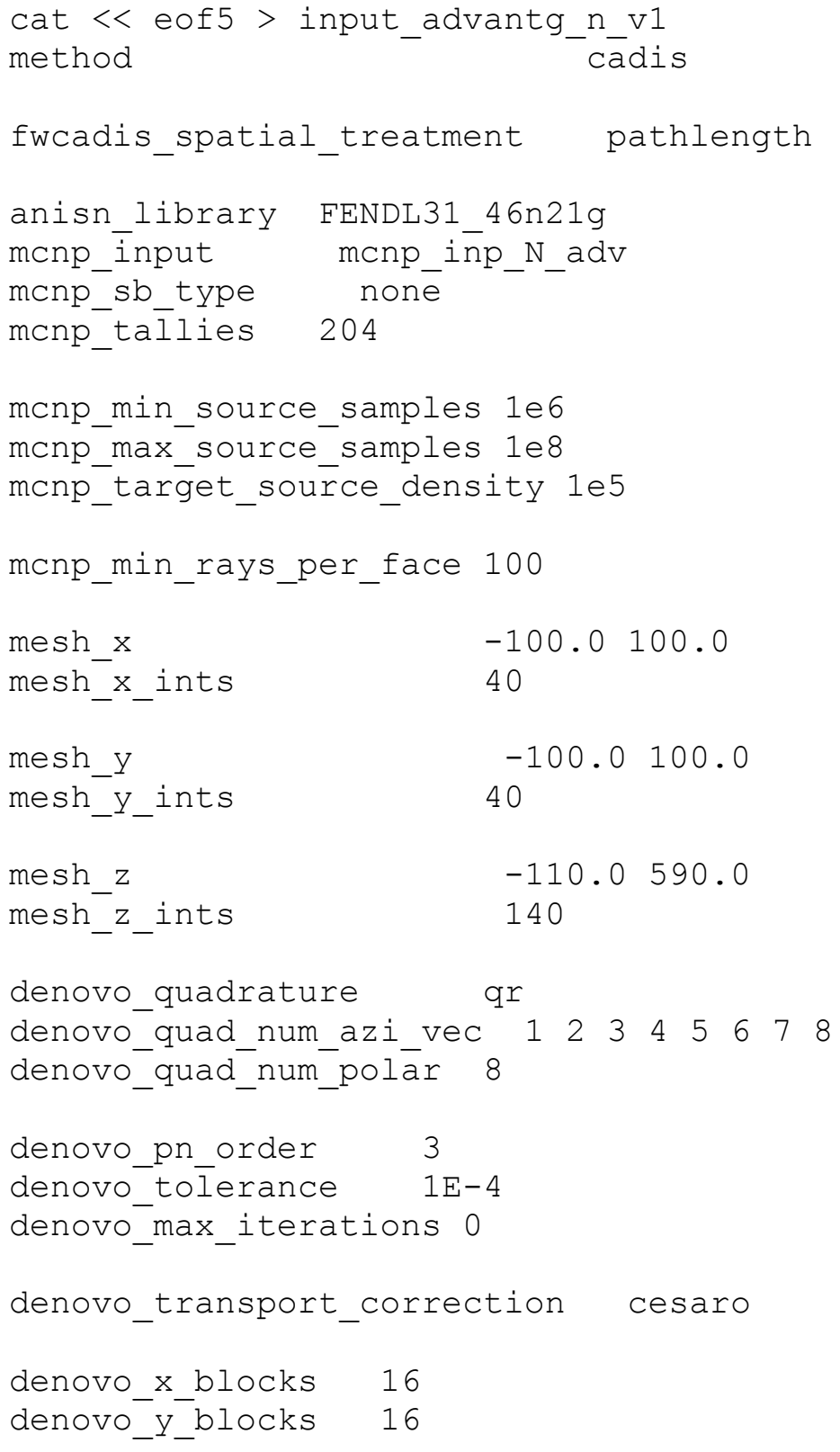




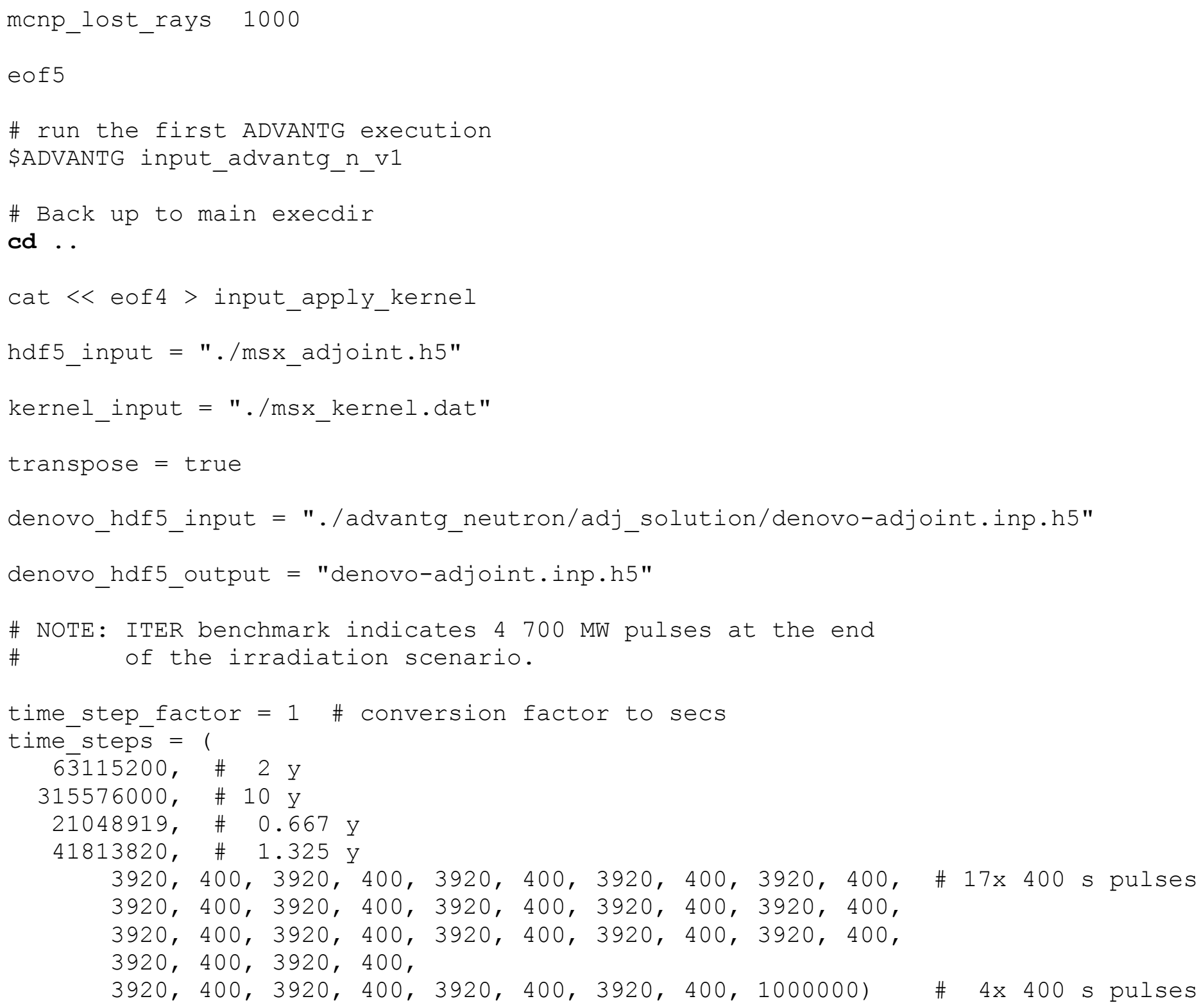




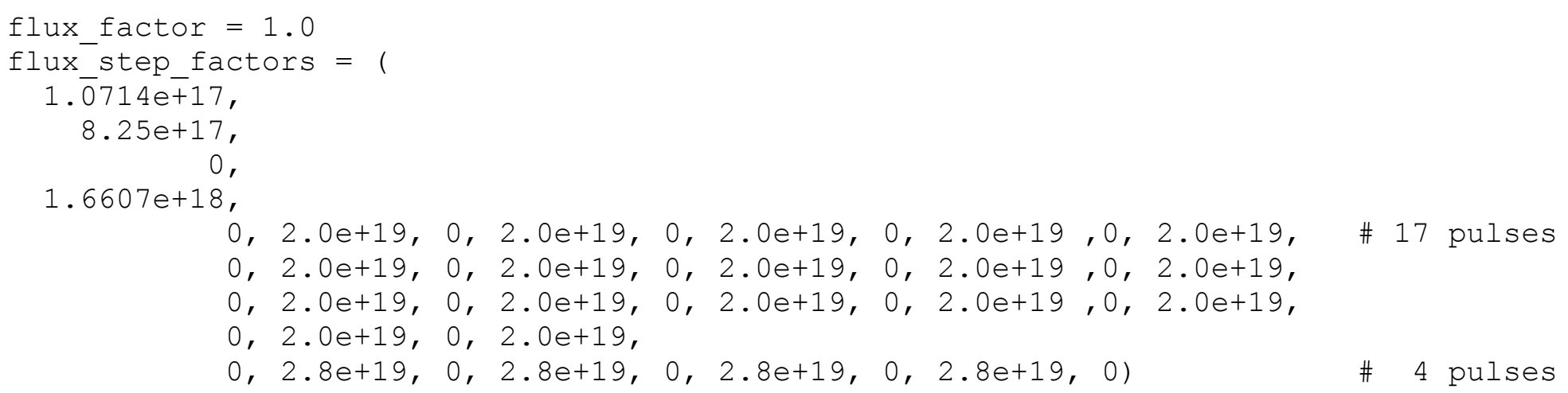

$\operatorname{eof} 4$

echo Applying kernel

\$MSX_APPLY_KERNEL input_apply_kernel

cp denovo-adjoint.inp.h5 ./advantg_neutron/adj_solution/denovo-adjoint.inp.h5

fi

\# step 5: make a neutron wwinp file

then

echo Beginning step 5

cd advantg_neutron

\# go into adj_solution

cd adj_solution

\# replace max iterations 0 in omnibus.inp.omn

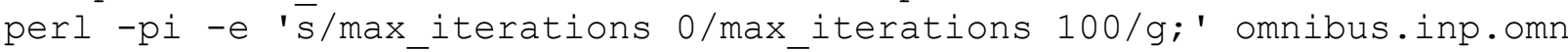

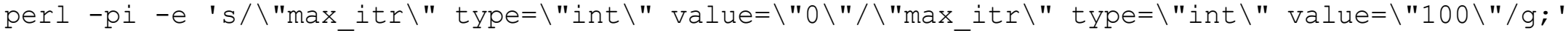
omnibus.inp.xml 


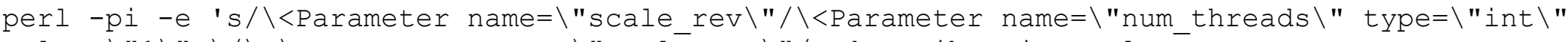
value $=\backslash " 1 \backslash " \backslash / \backslash>\backslash<$ Parameter name=\"scale_rev $\backslash " / g ; '$ omnibus.inp.xml

\# run Denovo with the kernel sources

mpiexec -np 256 /software/user_tools/current/cades-nsed-exnihilo/Exnihilo/bin/omnibus omnibus.inp.xml

\# back up to the advantg run directory

cd ..

\# force ADVANTG to run with the new adj_solution

\$ADVANTG input_advantg_n_v1

\# back up to main exec directory

cd . .

\section{fi}

$\#$

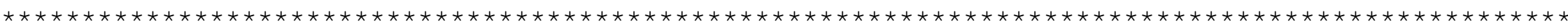

\# step 6: run MCNP to generate neutron meshtal

\# NOTE: run exterior script for this step

if [ "\$step6exec" = true]

then

echo Beginning step 6

if [ ! - d monp_neutron ]

then

mkdir manp neutron

fi

cd monp_neutron

$\mathrm{cp} . . / \mathrm{mcnp} \mathrm{inp}_{-} \mathrm{N}$.

ср ../config.

cat..ladvantg_neutron/output/inp_edits.txt >> menp_inp_N

In -s .. /advantg_neutron/output/wwinp wwinp_mscadis_neutron 
\# create $\mathrm{N}$ independent decks

NBERT $=16$

for $(($ ibert $=0$; ibert $\angle \mathrm{NBERT}$; ibert ++$))$;

do

( (qbert=ibert* $2+1)$ )

cp menp_inp_N menp_inp_N_\$ibert

echo RAN $\bar{N}$ GEN=2 SEED=\$q̄bert STRIDE=30239789 > card_\$ibert

cat card_\$ibert >> mcnp_inp_N_\$ibert

\section{done}

\# create OpenMPI stage and launch script

rm launch.bash

echo '\#! /bin/bash' >> launch.bash

echo '\#' >> launch.bash

echo 'echo Executing on rank \$OMPI COMM WORLD RANK' >> launch.bash

echo ' $r m-r$ temp_exec_\$OMPI_COMM_WORLD_RANK' $>>$ launch.bash

echo 'mkdir temp exec \$OMPI COMM WORLD RANK' $>>$ launch.bash

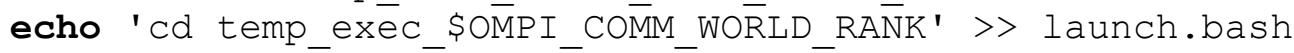

echo \$SRCORNLTN >> launch.bash

echo 'unset OMP_PLACES' >> launch.bash

echo 'export OMP PROC BIND=true' >> launch.bash

echo 'export DATA PATH='\$DATAPATH >> launch.bash

echo 'ln -s '\$EXECDIR'/mcnp_neutron/wwinp_mscadis_neutron .' >> launch.bash

echo 'In -s '\$EXECDIR'/mcnp_neutron/config.' >> Iaunch.bash

echo 'mv '\$EXECDIR'/mcnp_neuttron/mcnp_inp_N_\$OMPI_COMM_WORLD_RANK_' >> launch.bash

echo \$MCNP5BASEN' inp=mcnp inp $N$ \$OMPI COMM WORLD RANK outp=out \$OMPI COMM WORLD RANK

runtpe=trash wwinp=wwinp mscadis_neutron tasks 15' $>$ launch.bash

echo 'mv meshtal.h5 '\$EXECDIR'/mcnp neutron/meshtal n \$OMPI COMM WORLD RANK.h5' >> launch.bash

echo 'cd '\$EXECDIR'/mcnp_neutron' >> launch.bash

echo 'sleep 100' >> launch.bash

chmod u+rx launch.bash 


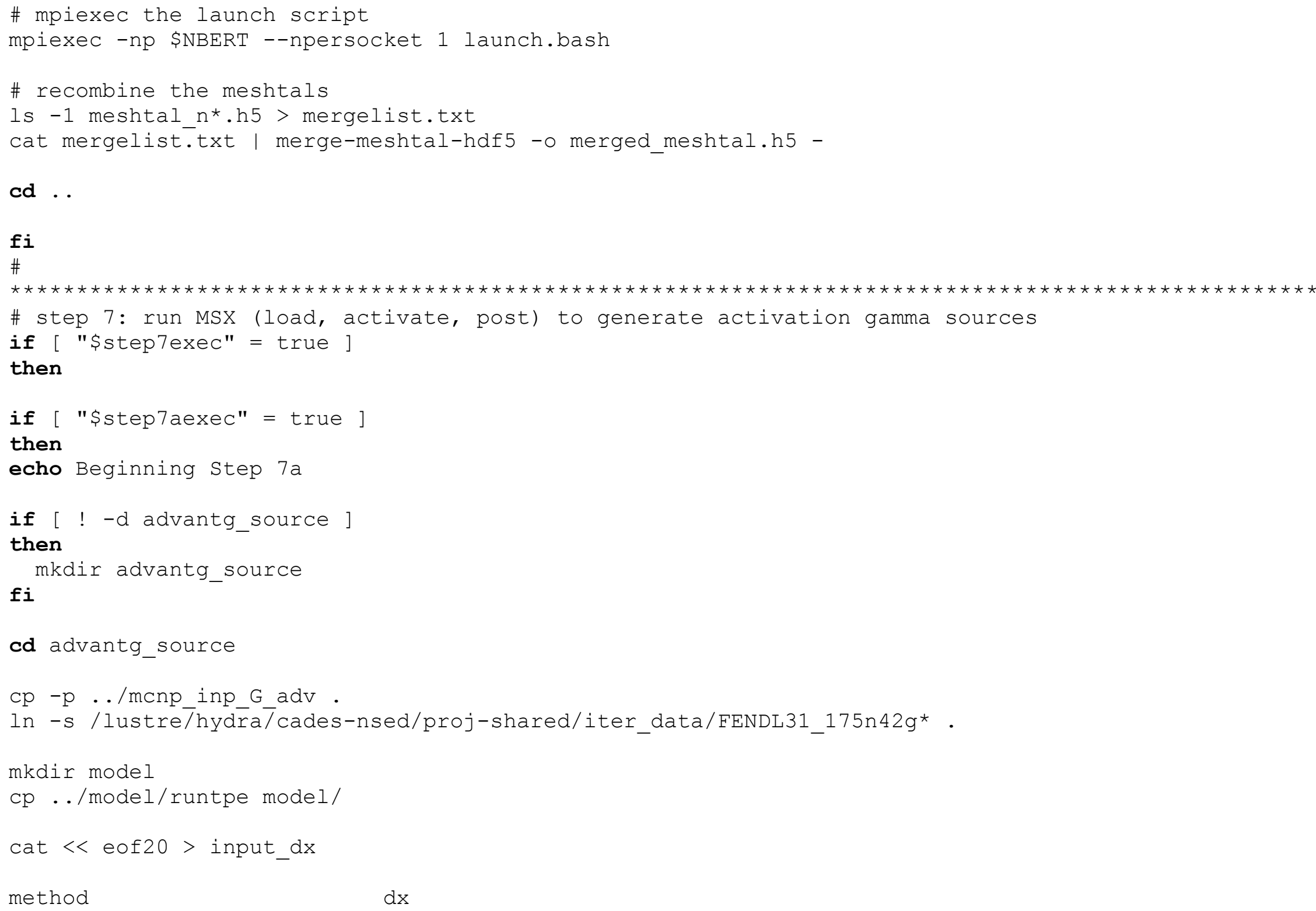




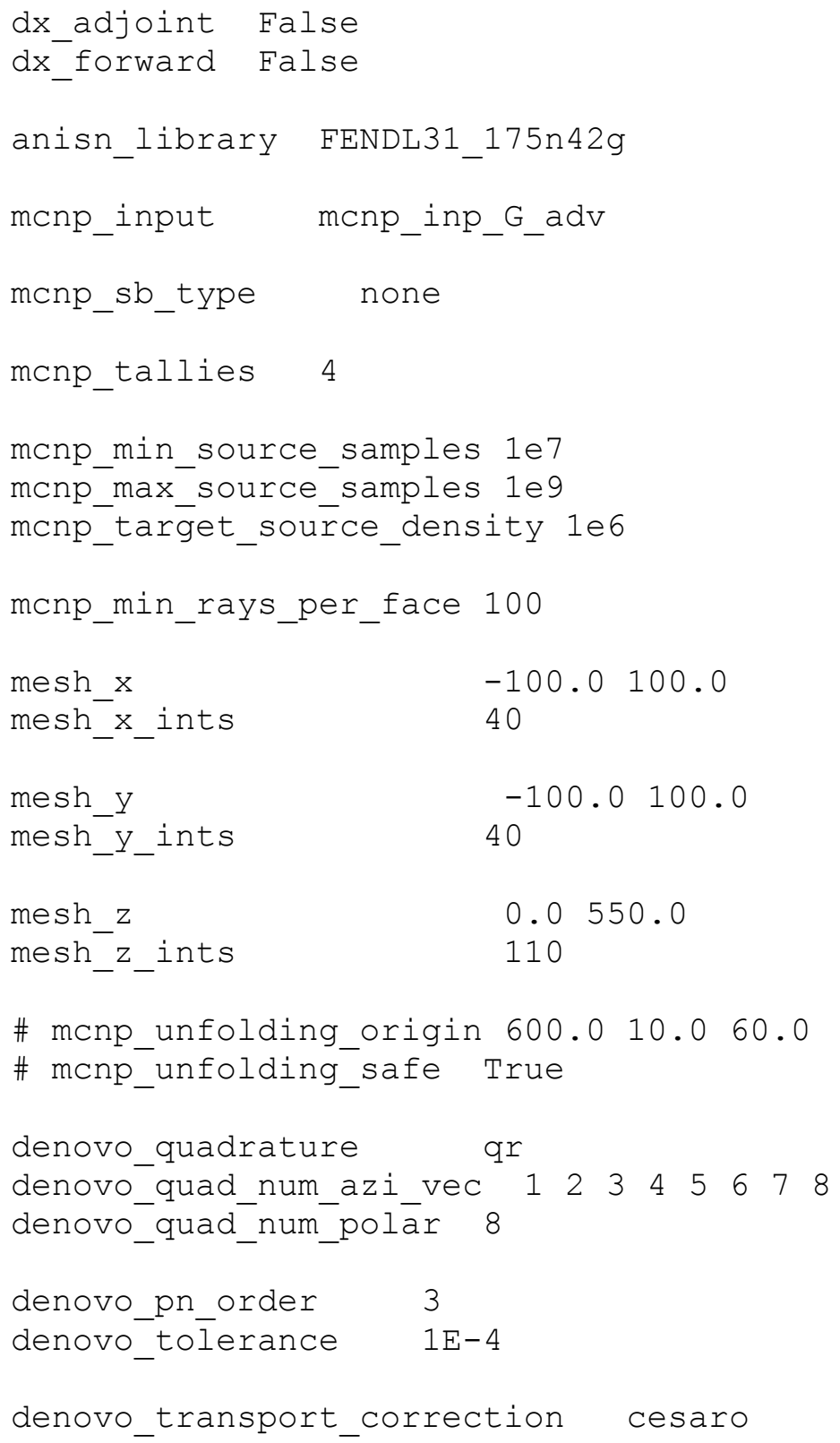




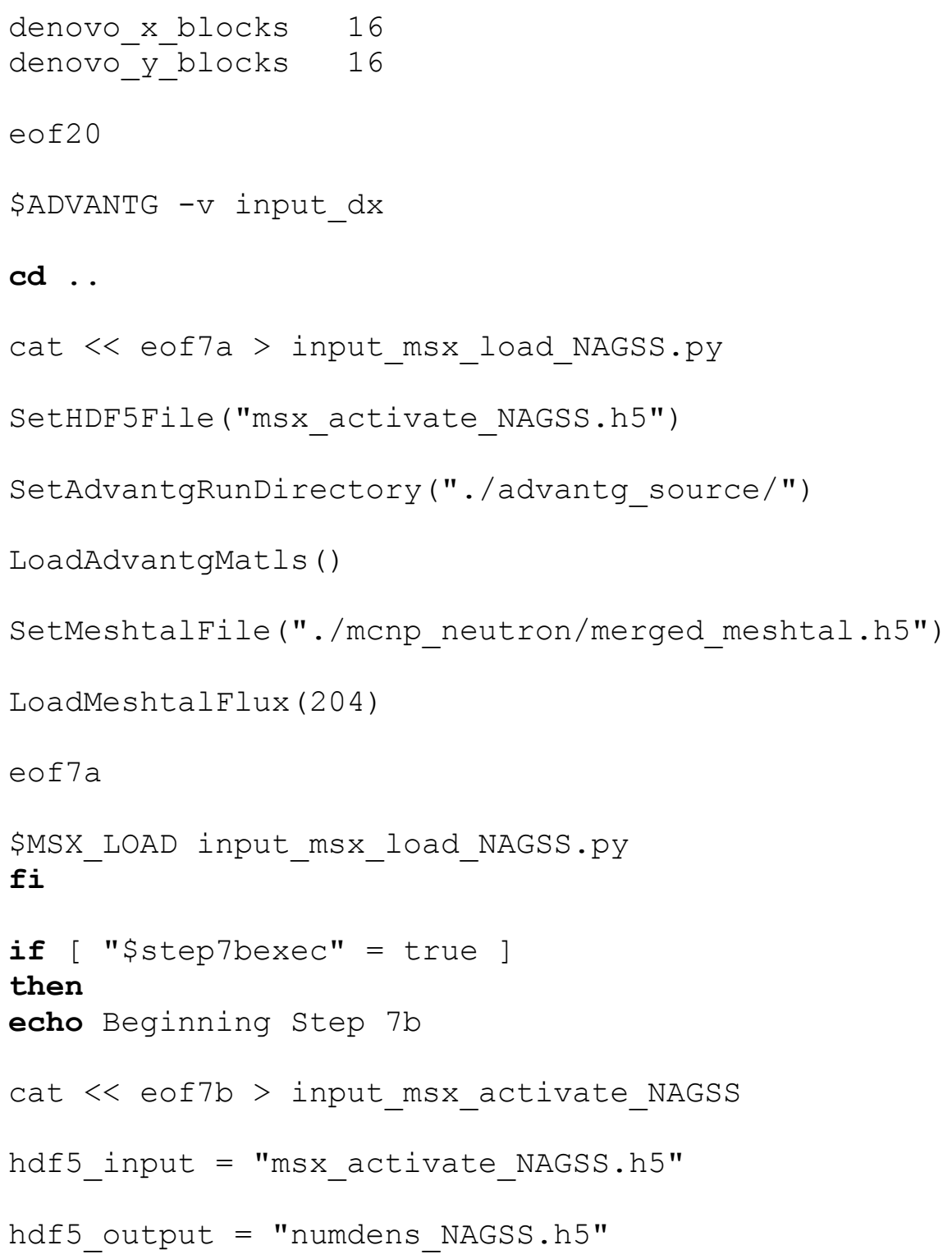


\# NOTE: ITER benchmark indicates 4700 MW pulses at the end

\# of the irradiation scenario.

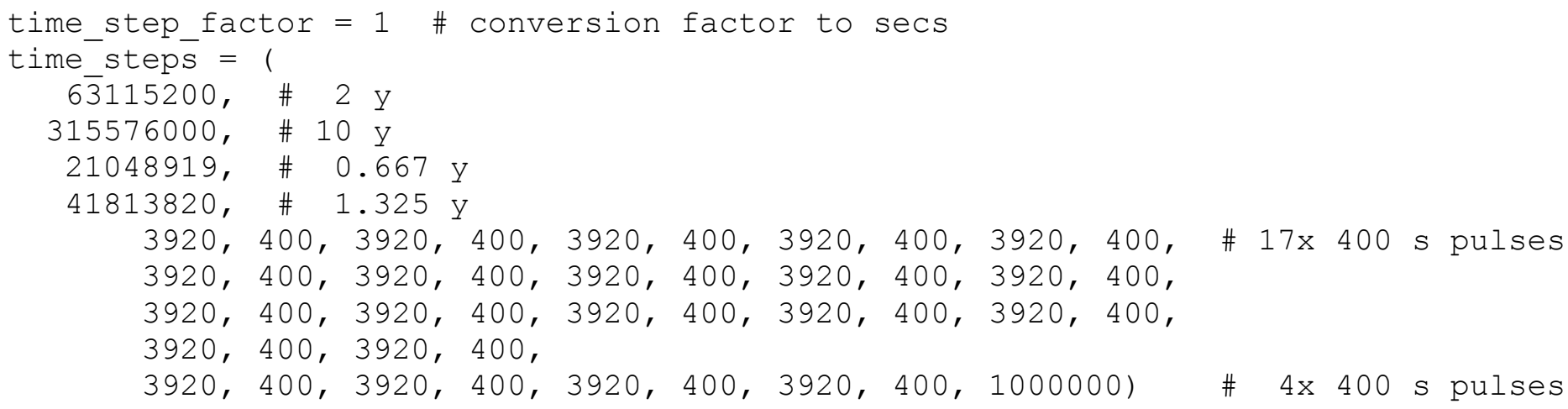

min_number_density $=1 \cdot 0 e-30$

eof $7 \mathrm{~b}$

\$MSX_ACTIVATE input_msx_activate_NAGSS

fi

if [ "\$step7cexec" = true ]

then 
echo Beginning step 7c

cat $<<$ eof7c $>$ input_msx_post_NAGSS.Py

infile = HDF5File ("numdens_NAGSS.h5","r")

groups $=$ Groups $([1.00000 \mathrm{E}+01,5.00000 \mathrm{E}+00$ $, 4.50000 \mathrm{E}+00,4.00000 \mathrm{E}+00$ $, 3.50000 \mathrm{E}+00,3.00000 \mathrm{E}+00$ $, 2.76000 \mathrm{E}+00,2.74000 \mathrm{E}+00$ $, 2.50000 \mathrm{E}+00,2.12000 \mathrm{E}+00$ $2.10000 \mathrm{E}+00,2.00000 \mathrm{E}+00$ $, 1.82000 \mathrm{E}+00,1.80000 \mathrm{E}+00$ $, 1.68000 \mathrm{E}+00,1.66000 \mathrm{E}+00$ $, 1.38300 \mathrm{E}+00,1.37000 \mathrm{E}+00$ $, 1.35000 \mathrm{E}+00,1.34000 \mathrm{E}+00$ $, 1.32000 \mathrm{E}+00,1.30000 \mathrm{E}+00$ $, 1.28000 \mathrm{E}+00,1.18000 \mathrm{E}+00$ $, 1.16000 \mathrm{E}+00,1.00000 \mathrm{E}+00$ $, 8.70000 \mathrm{E}-01,8.60000 \mathrm{E}-01$ $8.50000 \mathrm{E}-01,8.45000 \mathrm{E}-01$ $, 8.40000 \mathrm{E}-01,8.30000 \mathrm{E}-01$ $, 8.20000 \mathrm{E}-01,8.15000 \mathrm{E}-01$ $, 8.05000 \mathrm{E}-01,8.00000 \mathrm{E}-01$ $, 7.50000 \mathrm{E}-01,7.00000 \mathrm{E}-01$ $, 6.00000 E-01,5.20000 E-01$ $, 5.00000 \mathrm{E}-01,4.50000 \mathrm{E}-01$ , 4.00000E-01,3.00000E-01 $, 2.00000 \mathrm{E}-01,1.50000 \mathrm{E}-01$ $, 1.00000 \mathrm{E}-01,7.50000 \mathrm{E}-02$ $, 7.00000 \mathrm{E}-02,6.00000 \mathrm{E}-02$ $, 4.50000 \mathrm{E}-02,3.00000 \mathrm{E}-02$ $, 2.00000 \mathrm{E}-02,1.00000 \mathrm{E}-02$ $, 1.00000 \mathrm{E}-03])$

print groups.num_groups

print groups.bounds 


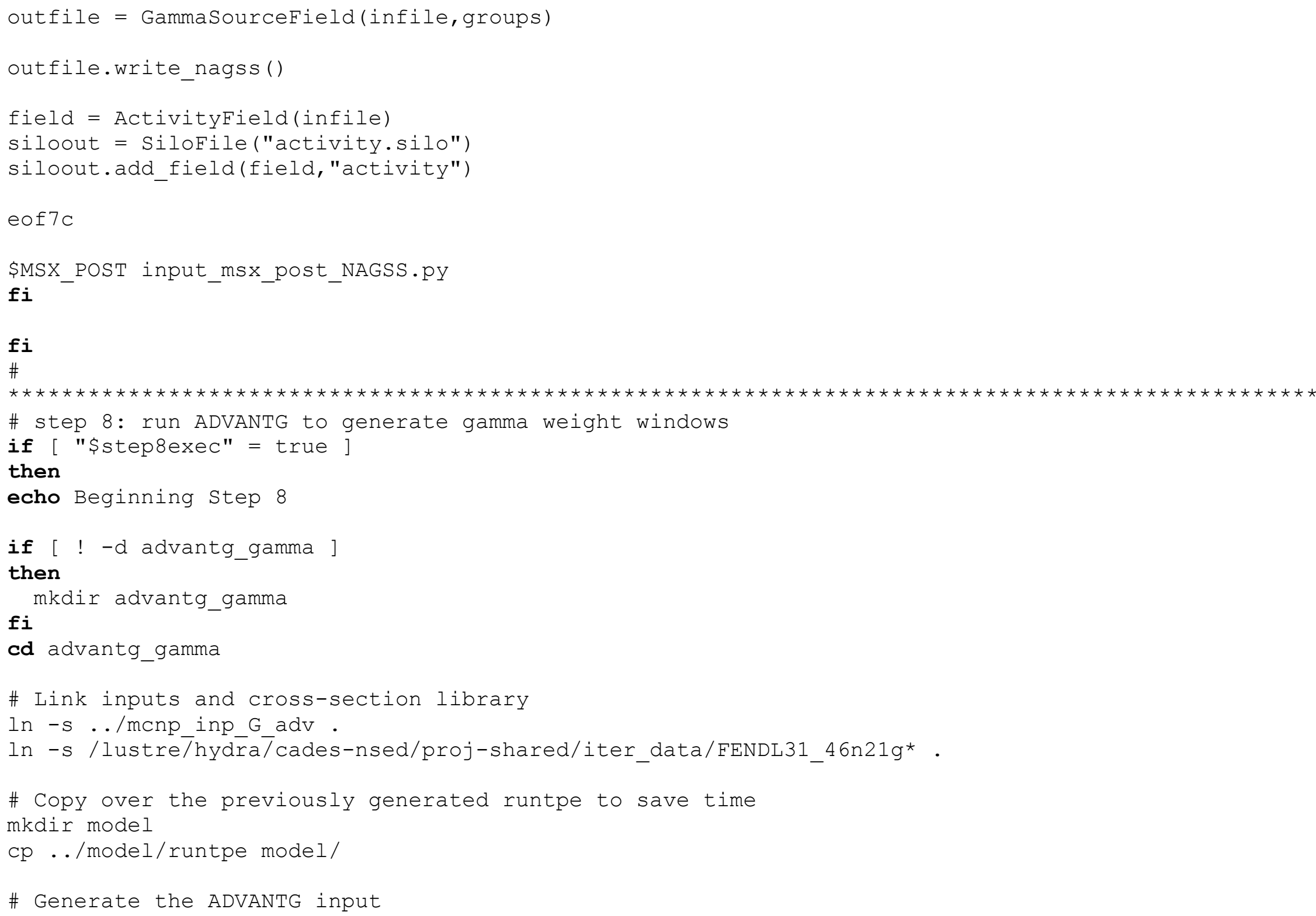


cat $<<$ eof $8>$ input_photon_CADIS

method

cadis

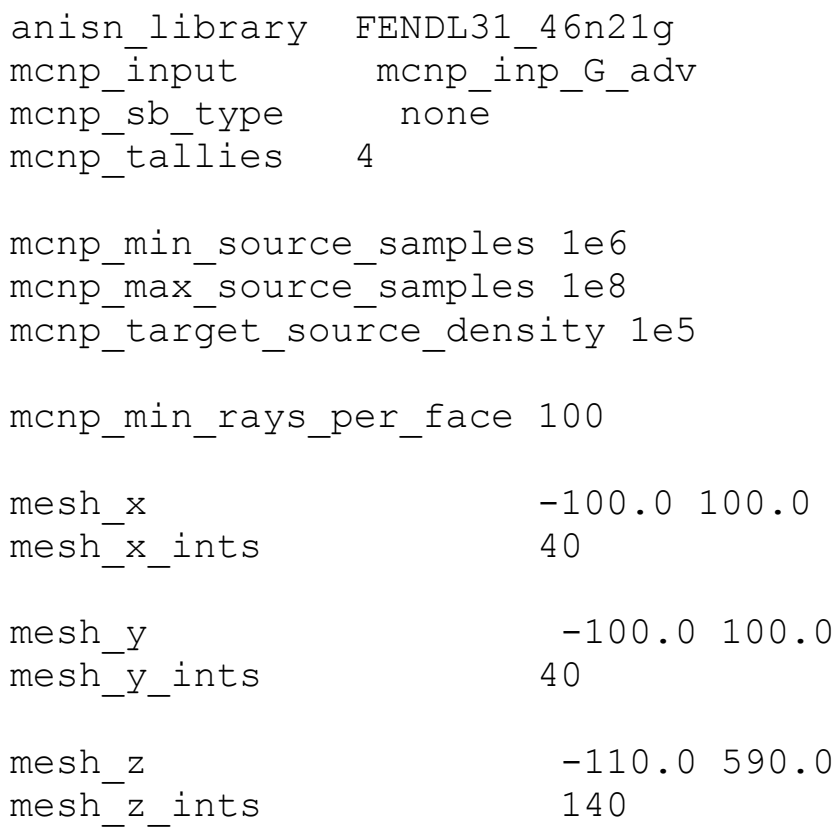

eof 8 
\# Run ADVANTG to generate the gamma weight windows \$ADVANTG input_photon_CADIS

$\operatorname{cd}$.

fi

\#

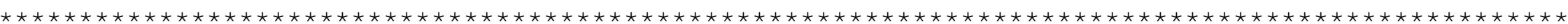

\# step 9: run NAGSS to generate MCNP source

if [ "\$step9exec" = true ]

then

echo Beginning step 9

export OMP_PROC_BIND=TRUE

\# Link needed files

In -s./advantg_gamma/output/wwinp wwinp_mscadis_gamma

In -s ./advantg gamma/output/inp edits.txt .

ln $-s$ model/runtpe blarg

\# NAGSS input

\# number of energy group files to search for

\# number of batches to sample

\# number of samples per batch per thread

\# number of threads to execute

\# number of random MCNP output files

\# path to gamma ww

\# path to gamma inp_edits (with response value)

\# number of sdef point sources if run in sdef mode

cat $<<$ eof $9>$ nagss.inp

55

10

100000

16

256 
. /wwinp_mscadis_gamma

. / inp èdits.txt

1000

eof 9

\$NAGSS - sample > nagss log.out

fi

$\#$

\# step 10: run MCNP to generate MCNP gamma results

if [ "\$step10exec" = true ]

then

echo Beginning step 10

if [ ! -d monp gamma ]

then

fi

mkdir menp gamma

cd menp_gamma

cp ../menp_inp_G .

cp . . / config_G config

ln -s .../nagss_random* .

In -s .. /advantg gamma/output/wwinp.

In -s .../advantg_gamma/output/inp_edits.txt

cat inp_edits.txt $>$ monp_inp_G

NBERT $=16$

for $((i b e r t=0$; ibert $<\mathrm{NBERT}$; ibert ++$))$; do

$($ (qbert=ibert* $2+1)$ )

cp manp_inp_G manp_inp_G \$ibert

echo RAND GEN=2 SEED=\$qbert STRIDE=30239789 > card_\$ibert

cat card_\$ibert $>$ monp_inp_G_\$ibert 


\section{done}

\# create OpenMPI stage and launch script

rm launch.bash

echo '\#! /bin/bash' >> launch.bash

echo '\#' >> launch.bash

echo 'echo Executing on rank \$OMPI COMM WORLD RANK' >> launch.bash

echo ' $r m-r$ temp_exec_\$OMPI_COMM_WORLD_RANK' $\gg$ launch.bash

echo 'mkdir temp exec $\$ O M P I$ COMM WORLD RANK' > launch.bash

echo 'In -s '\$EXĒCDIR'/mcnp_gammā/wwinp temp_exec_\$OMPI_COMM_WORLD_RANK' >> launch.bash

echo 'In -s '\$EXECDIR'/mcnp_gamma/config temp_exec_\$OMPI_COMM_WORLD_RANK' >> launch.bash

echo 'cp '\$EXECDIR'/mcnp_gamma/mcnp_inp_G_\$OMPI_COMM WORËD_RAN̄K temp_exec_\$OMPI_COMM_WORLD_RANK'

$>$ launch.bash

echo 'NTASKS=16' >> launch.bash

echo 'rank $=\$ O M P I$ COMM_WORLD_RANK' $>>$ launch.bash

echo 'for ( (iber $\bar{t}=0$; ibert<NTASKS; ibert++)); do' >> launch.bash

echo ' ( (qbert=NTASKS*rank+ibert)) ' >> launch.bash

echo' echo copying source file \$qbert to local file \$ibert' >> launch.bash

echo ' In -s '\$EXECDIR'/mcnp_gamma/nagss_random_source_\$qbert

temp_exec_\$OMPI_COMM_WORLD_RANK/nagss_random_source_\$ibert' >> launch.bash

ech̄o 'dōne' >⿳亠丷厂 lauñch.bašsh

echo 'cd temp_exec_\$OMPI_COMM_WORLD_RANK' >> launch.bash

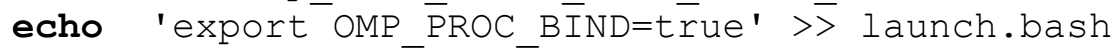

echo 'chmod u+rwx ${ }^{*}$ ' $>$ ' launch.bash

echo \$MCNP5BASEG' inp=menp inp G \$OMPI COMM WORLD RANK outp=out gamma \$OMPI COMM WORLD RANK

runtpe=trash wwinp=wwinp tasks $1 \overline{5}{ }^{\prime}>>$ launch. bash

echo 'mv meshtal.h5 '\$EXECDIR'/mcnp gamma/meshtal g \$OMPI COMM WORLD RANK.h5' >> launch.bash

echo 'mv mctal '\$EXECDIR'/mcnp_gamma/mctal_g_\$OMPI_COMM_WORLD_RANK' $>>$ launch.bash

echo 'sleep 100' >> launch.bash

chmod u+rx launch.bash

\# mpiexec the launch script

mpiexec -np 16 --npersocket 1 launch.bash 
Is -1 meshtal_g* > mergelist.txt

cat mergelist.txt | merge-meshtal-hdf5 -o merged_meshtal.h5 -

\# merge the mctals as well

merge_mctal mctal*

fi

exit 
APPENDIX B. COMPUTER CODE INPUTS 



\section{APPENDIX B. MCNP AND ORNL-TN INPUTS}

\section{menp_inp_G}

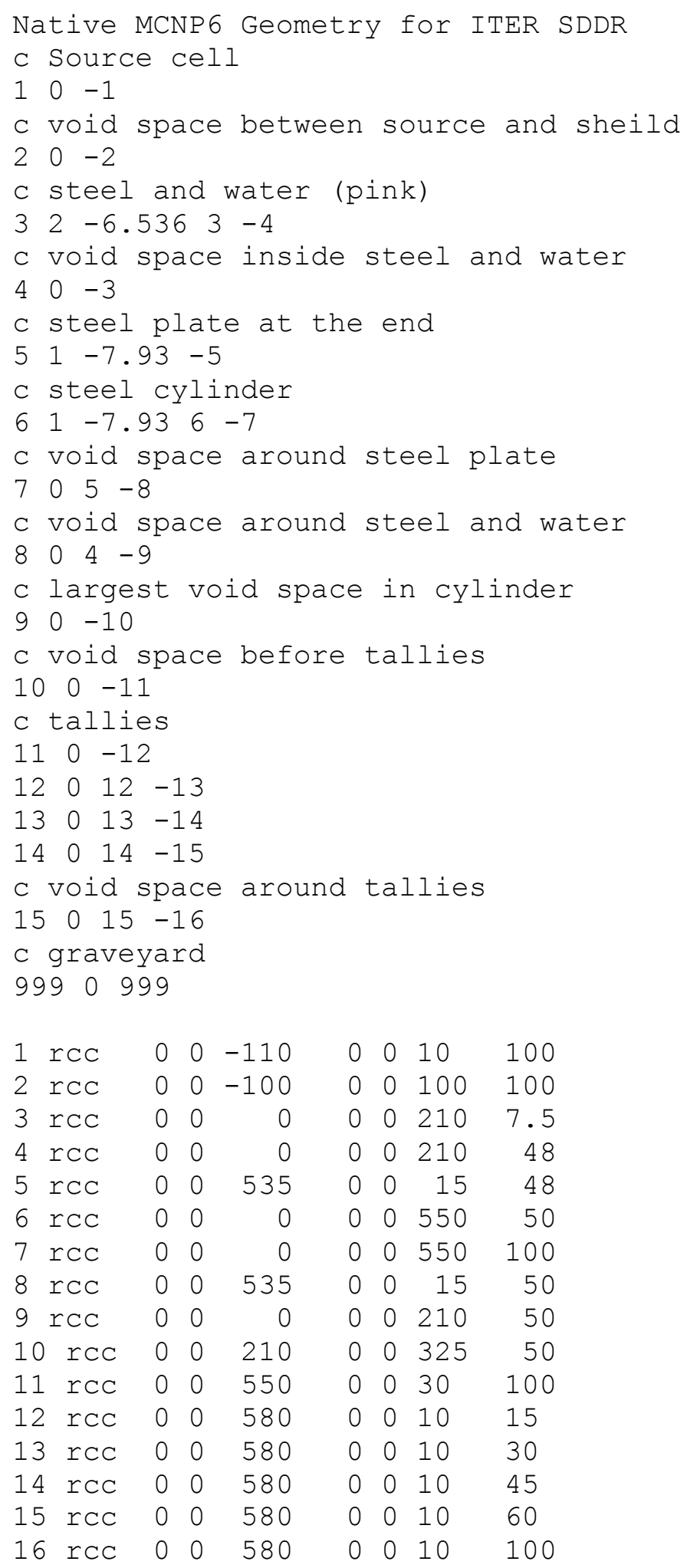




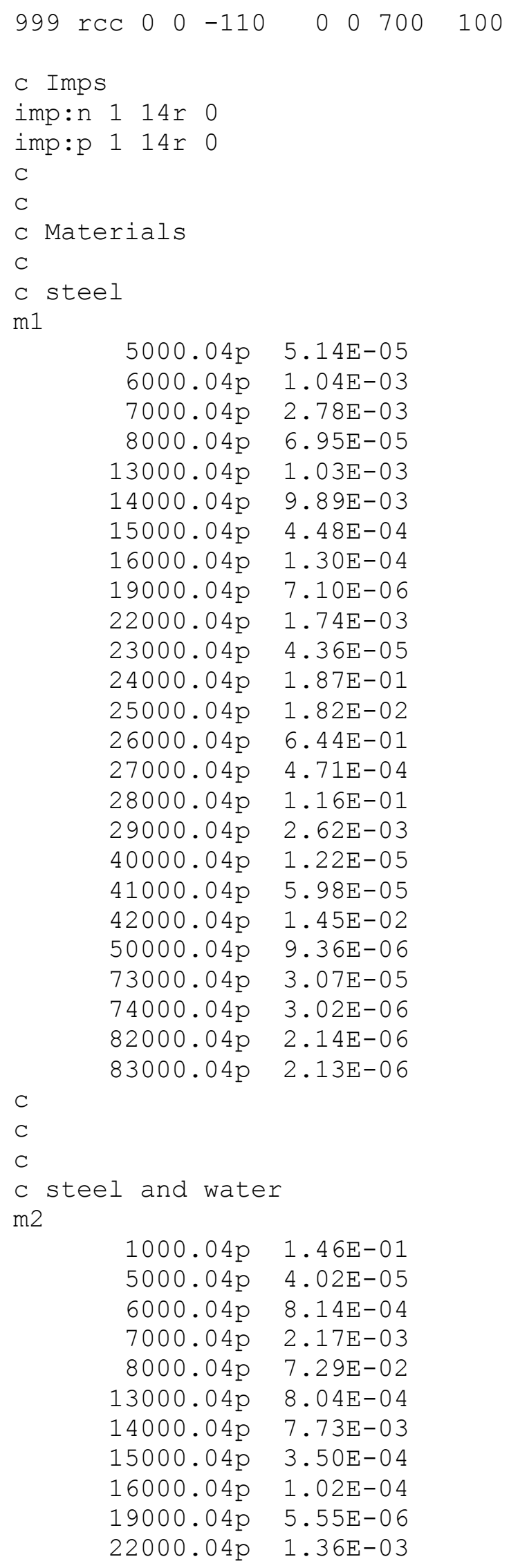




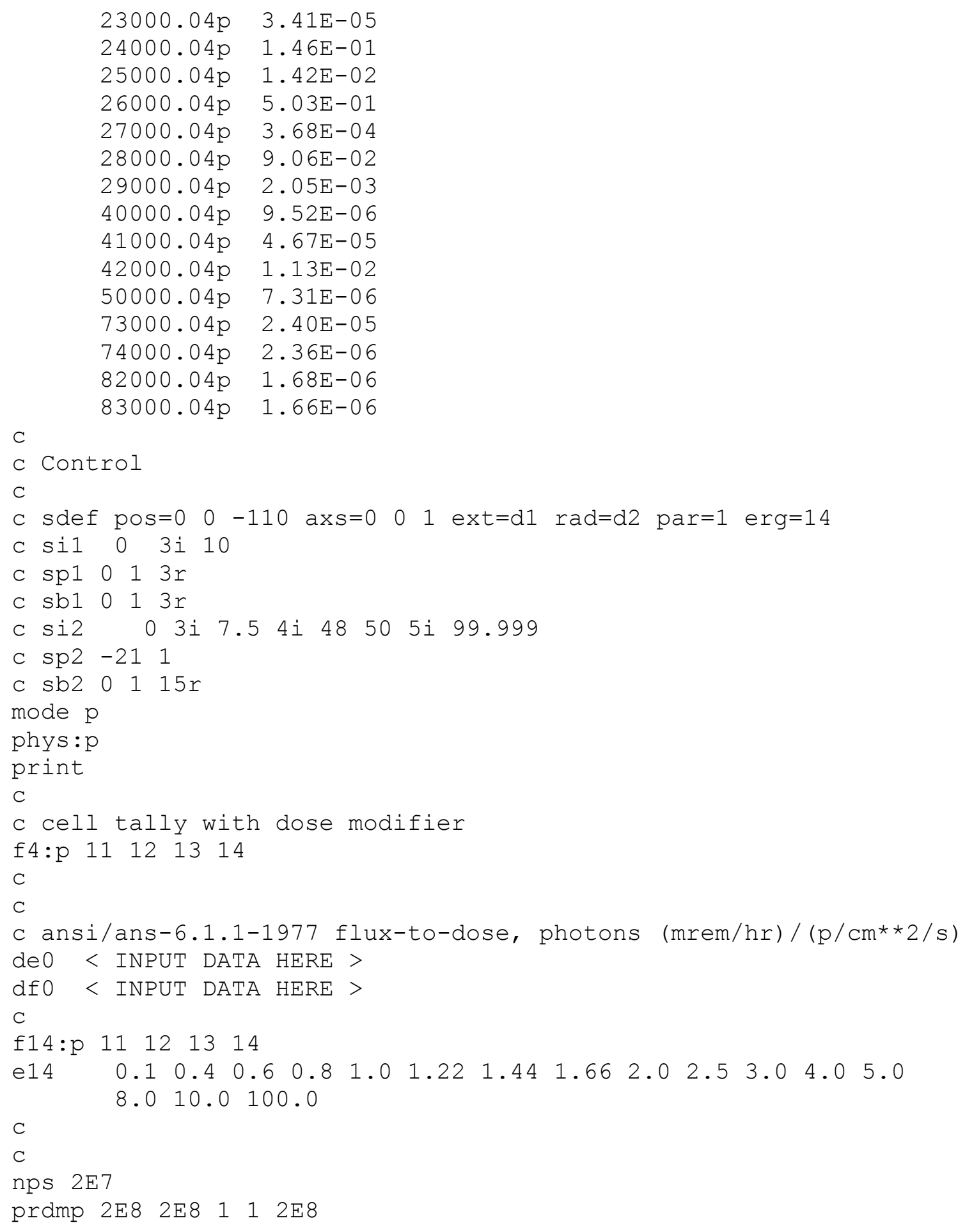




\section{monp_inp_G_adv}

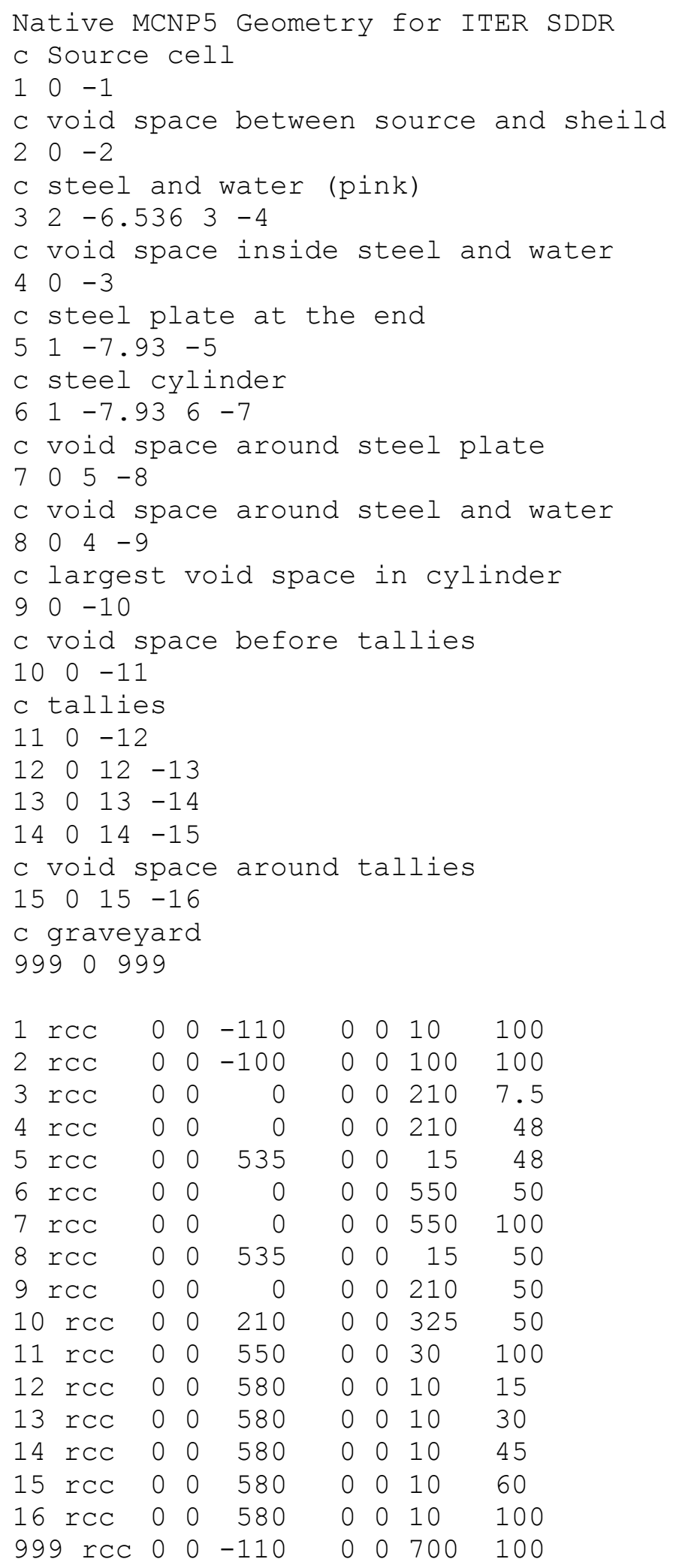




\begin{tabular}{|c|c|c|c|}
\hline \multicolumn{4}{|c|}{ c Imps } \\
\hline \multicolumn{4}{|c|}{$i m p: n \quad 1$ 14r 0} \\
\hline \multirow{2}{*}{\multicolumn{4}{|c|}{ imp:p 1 14r 0}} \\
\hline & & & \\
\hline \\
\hline \multirow{2}{*}{\multicolumn{4}{|c|}{ Materials }} \\
\hline & & & \\
\hline \multicolumn{4}{|c|}{ m1 } \\
\hline \multirow[t]{3}{*}{$\mathrm{C}$} & 5000 & $5.14 \mathrm{E}-05$ & B \\
\hline & $5010.21 \mathrm{C}$ & $1.02 \mathrm{E}-05$ & \\
\hline & $5011.21 \mathrm{C}$ & $4.12 \mathrm{E}-05$ & \\
\hline \multirow[t]{2}{*}{ C } & $6000.21 c$ & $1.04 E-03$ & $\mathrm{C}$ \\
\hline & $6012.21 c$ & $1.04 \mathrm{E}-03$ & \\
\hline \multirow[t]{3}{*}{ C } & 7000 & $2.78 E-03$ & $\mathrm{~N}$ \\
\hline & $7014.21 c$ & $2.77 \mathrm{E}-03$ & \\
\hline & $7015.21 c$ & $1.01 \mathrm{E}-05$ & \\
\hline \multirow[t]{2}{*}{ C } & 8000 & $6.95 E-05$ & 0 \\
\hline & $8016.21 \mathrm{C}$ & $6.95 \mathrm{E}-05$ & \\
\hline \multirow[t]{2}{*}{ C } & 13000 & $1.03 \mathrm{E}-03$ & $A 1$ \\
\hline & $13027.21 \mathrm{C}$ & $1.03 E-03$ & \\
\hline \multirow[t]{4}{*}{ C } & $14000.21 c$ & $9.89 \mathrm{E}-03$ & $\mathrm{Si}$ \\
\hline & $14028.21 \mathrm{C}$ & $9.12 \mathrm{E}-03$ & \\
\hline & $14029.21 \mathrm{C}$ & $4.63 E-04$ & \\
\hline & $14030.21 \mathrm{C}$ & $3.06 E-04$ & \\
\hline \multirow[t]{2}{*}{ C } & 15000 & $4.48 E-04$ & $\mathrm{P}$ \\
\hline & $15031.21 \mathrm{C}$ & 4. $48 E-04$ & \\
\hline \multirow[t]{5}{*}{ C } & $16000.21 \mathrm{C}$ & $1.30 E-04$ & S \\
\hline & $16032.31 c$ & $1.23 E-04$ & \\
\hline & $16033.31 \mathrm{c}$ & $9.75 E-07$ & \\
\hline & $16034.31 \mathrm{C}$ & $5.53 E-06$ & \\
\hline & $16036.31 \mathrm{C}$ & 1. $30 E-08$ & \\
\hline \multirow[t]{4}{*}{ C } & $19000.21 \mathrm{C}$ & $7.10 \mathrm{E}-06$ & K \\
\hline & $19039.31 \mathrm{C}$ & $6.62 E-06$ & \\
\hline & $19040.31 \mathrm{C}$ & $8.31 E-10$ & \\
\hline & $19041.31 \mathrm{C}$ & $4.78 \mathrm{E}-07$ & \\
\hline \multirow[t]{6}{*}{$\mathrm{C}$} & $22000.21 \mathrm{C}$ & C $1.74 \mathrm{E}-03$ & $\mathrm{Ti}$ \\
\hline & $22046.21 c$ & $1.44 \mathrm{E}-04$ & \\
\hline & $22047.21 c$ & $1.29 \mathrm{E}-04$ & \\
\hline & $22048.21 c$ & $1.28 \mathrm{E}-03$ & \\
\hline & $22049.21 c$ & $9.41 E-05$ & \\
\hline & $22050.21 c$ & $9.01 E-05$ & \\
\hline \multirow[t]{3}{*}{ C } & $23000.21 \mathrm{C}$ & $C 4.36 E-05$ & $\mathrm{~V}$ \\
\hline & $23050.31 c$ & $1.09 \mathrm{E}-07$ & \\
\hline & $23051.31 c$ & $4.35 E-05$ & \\
\hline C & $24000.21 \mathrm{C}$ & $1.87 \mathrm{E}-01$ & $\mathrm{Cr}$ \\
\hline & $24050.21 c$ & $8.13 \mathrm{E}-03$ & \\
\hline & $24052.21 c$ & $1.57 \mathrm{E}-01$ & \\
\hline & $24053.21 c$ & $1.78 \mathrm{E}-02$ & \\
\hline & $24054.21 c$ & $4.42 E-03$ & \\
\hline C & 25000 & $1.82 \mathrm{E}-02$ & $\mathrm{Mn}$ \\
\hline & $25055.21 c$ & 1. 82E-02 & \\
\hline
\end{tabular}




\begin{tabular}{|c|c|c|c|}
\hline$C$ & $26000.21 c$ & $6.44 \mathrm{E}-01$ & $\mathrm{Fe}$ \\
\hline & $26054.21 \mathrm{c}$ & $3.76 \mathrm{E}-02$ & \\
\hline & $26056.21 \mathrm{c}$ & $5.91 \mathrm{E}-01$ & \\
\hline & $26057.21 \mathrm{C}$ & $1.36 \mathrm{E}-02$ & \\
\hline & $26058.21 \mathrm{c}$ & $1.82 \mathrm{E}-03$ & \\
\hline & 27000 & $4.71 \mathrm{E}-04$ & $\mathrm{Co}$ \\
\hline & $27059.21 \mathrm{c}$ & $4.71 \mathrm{E}-04$ & \\
\hline & $28000.21 \mathrm{c}$ & $1.16 \mathrm{E}-01$ & $\mathrm{Ni}$ \\
\hline & $28058.21 c$ & $7.90 \mathrm{E}-02$ & \\
\hline & $28060.21 \mathrm{c}$ & $3.04 E-02$ & \\
\hline & $28061.21 \mathrm{C}$ & 1. $32 \mathrm{E}-03$ & \\
\hline & $28062.21 \mathrm{c}$ & $4.22 E-03$ & \\
\hline & $28064.21 \mathrm{c}$ & $1.07 E-03$ & \\
\hline & $29000.21 c$ & $2.62 E-03$ & $\mathrm{Cu}$ \\
\hline & $29063.21 \mathrm{C}$ & $1.81 E-03$ & \\
\hline & $29065.21 \mathrm{C}$ & $8.08 \mathrm{E}-04$ & \\
\hline & $40000.21 \mathrm{c}$ & $1.22 \mathrm{E}-05$ & Zr \\
\hline & $40090.31 \mathrm{C}$ & $6.28 \mathrm{E}-06$ & \\
\hline & $40091.31 \mathrm{C}$ & $1.37 E-06$ & \\
\hline & $40092.31 \mathrm{C}$ & $2.09 \mathrm{E}-06$ & \\
\hline & $40094.31 \mathrm{C}$ & $2.12 E-06$ & \\
\hline & $40096.31 \mathrm{C}$ & $3.42 E-07$ & \\
\hline & 41000 & $5.98 \mathrm{E}-05$ & $\mathrm{Nb}$ \\
\hline & $41093.21 \mathrm{C}$ & $5.98 \mathrm{E}-05$ & \\
\hline & $42000.21 c$ & 1. $45 E-02$ & Mo \\
\hline & $42092.21 \mathrm{C}$ & $2.11 E-03$ & \\
\hline & $42094.21 \mathrm{C}$ & $1.33 \mathrm{E}-03$ & \\
\hline & $42095.21 \mathrm{c}$ & $2.30 \mathrm{E}-03$ & \\
\hline & $42096.21 \mathrm{C}$ & $2.42 E-03$ & \\
\hline & $42097.21 \mathrm{C}$ & $1.39 \mathrm{E}-03$ & \\
\hline & $42098.21 \mathrm{C}$ & $3.54 \mathrm{E}-03$ & \\
\hline & $42100.21 \mathrm{C}$ & $1.42 \mathrm{E}-03$ & \\
\hline & $50000.21 c$ & $9.36 \mathrm{E}-06$ & $\mathrm{Sn}$ \\
\hline & $50112.31 c$ & $9.08 \mathrm{E}-08$ & \\
\hline & $50114.31 \mathrm{c}$ & $6.18 \mathrm{E}-08$ & \\
\hline & $50115.31 \mathrm{c}$ & $3.18 \mathrm{E}-08$ & \\
\hline & $50116.31 \mathrm{c}$ & $1.36 \mathrm{E}-06$ & \\
\hline & $50117.31 \mathrm{c}$ & $7.19 \mathrm{E}-07$ & \\
\hline & $50118.31 \mathrm{C}$ & $2.27 E-06$ & \\
\hline & $50119.31 \mathrm{c}$ & $8.04 \mathrm{E}-07$ & \\
\hline & $50120.31 c$ & $3.05 E-06$ & \\
\hline & $50122.31 c$ & $4.33 \mathrm{E}-07$ & \\
\hline & $50124.31 \mathrm{C}$ & $5.42 \mathrm{E}-07$ & \\
\hline & $73000.21 c$ & $3.07 E-05$ & $\mathrm{Ta}$ \\
\hline & $73181.21 \mathrm{C}$ & $3.07 E-05$ & \\
\hline & $74000.21 \mathrm{c}$ & $3.02 E-06$ & W \\
\hline & $74180.31 \mathrm{C}$ & $3.62 E-09$ & \\
\hline & $74182.21 \mathrm{C}$ & $8.00 \mathrm{E}-07$ & \\
\hline & $74183.21 \mathrm{C}$ & $4.32 E-07$ & \\
\hline & $74184.21 \mathrm{C}$ & $9.25 E-07$ & \\
\hline & $74186.21 c$ & $8.59 \mathrm{E}-07$ & \\
\hline & $0.21 c$ & $=\quad 2.14 \mathrm{E}-06$ & \\
\hline
\end{tabular}




\begin{tabular}{|c|c|c|c|}
\hline & & & \\
\hline & & $3.00 \mathrm{E}-08$ & \\
\hline & $82206.21 c$ & $5.16 \mathrm{E}-07$ & \\
\hline & $82207.21 \mathrm{C}$ & $4.73 E-07$ & \\
\hline & $82208.21 \mathrm{C}$ & $1.12 \mathrm{E}-06$ & \\
\hline C & 83000 & $2.13 E-06$ & $\mathrm{Bi}$ \\
\hline & $83209.21 \mathrm{C}$ & $2.13 E-06$ & \\
\hline C & & & \\
\hline C & & & \\
\hline C & & & \\
\hline & el and wate & & \\
\hline m2 & & & \\
\hline C & 1000 & $1.46 \mathrm{E}-01$ & $\mathrm{H}$ \\
\hline & $1001.21 c$ & $1.46 \mathrm{E}-01$ & \\
\hline & $1002.21 c$ & $1.68 \mathrm{E}-05$ & \\
\hline C & 5000 & $4.02 E-05$ & B \\
\hline & $5010.21 c$ & $8.00 E-06$ & \\
\hline & $5011.21 c$ & $3.22 \mathrm{E}-05$ & \\
\hline C & $6000.21 \mathrm{c}$ & $8.14 \mathrm{E}-04$ & $\mathrm{C}$ \\
\hline & $6012.21 c$ & $8.14 \mathrm{E}-04$ & \\
\hline C & 7000 & $2.17 E-03$ & $\mathrm{~N}$ \\
\hline & $7014.21 c$ & $2.16 \mathrm{E}-03$ & \\
\hline & $7015.21 c$ & $7.90 \mathrm{E}-06$ & \\
\hline C & 8000 & $7.29 E-02$ & 0 \\
\hline & $8016.21 c$ & $7.29 \mathrm{E}-02$ & \\
\hline C & 13000 & $8.04 \mathrm{E}-04$ & Al \\
\hline & $13027.21 \mathrm{C}$ & $8.04 \mathrm{E}-04$ & \\
\hline C & $14000.21 \mathrm{C}$ & $7.73 E-03$ & $\mathrm{Si}$ \\
\hline & $14028.21 \mathrm{C}$ & $7.13 E-03$ & \\
\hline & $14029.21 \mathrm{C}$ & $3.62 \mathrm{E}-04$ & \\
\hline & $14030.21 \mathrm{C}$ & $2.39 E-04$ & \\
\hline C & 15000 & $3.50 \mathrm{E}-04$ & $\mathrm{P}$ \\
\hline & $15031.21 \mathrm{C}$ & $3.50 \mathrm{E}-04$ & \\
\hline C & $16000.21 \mathrm{c}$ & $1.02 E-04$ & S \\
\hline & $16032.31 \mathrm{C}$ & $9.69 \mathrm{E}-05$ & \\
\hline & $16033.31 \mathrm{c}$ & $7.65 E-07$ & \\
\hline & $16034.31 \mathrm{c}$ & $4.34 E-06$ & \\
\hline & $16036.31 \mathrm{c}$ & $1.02 \mathrm{E}-08$ & \\
\hline C & $19000.21 \mathrm{C}$ & $5.55 \mathrm{E}-06$ & K \\
\hline & $19039.31 \mathrm{C}$ & $5.18 \mathrm{E}-06$ & \\
\hline & $19040.31 \mathrm{C}$ & $6.49 \mathrm{E}-10$ & \\
\hline & $19041.31 \mathrm{C}$ & $3.74 \mathrm{E}-07$ & \\
\hline C & $22000.21 \mathrm{C}$ & $1.36 \mathrm{E}-03$ & $\mathrm{Ti}$ \\
\hline & $22046.21 \mathrm{C}$ & $1.12 \mathrm{E}-04$ & \\
\hline & $22047.21 \mathrm{C}$ & $1.01 \mathrm{E}-04$ & \\
\hline & $22048.21 c$ & $1.00 \mathrm{E}-03$ & \\
\hline & $22049.21 \mathrm{C}$ & $7.36 \mathrm{E}-05$ & \\
\hline & $22050.21 \mathrm{C}$ & $7.04 \mathrm{E}-05$ & \\
\hline C & $23000.21 \mathrm{C}$ & $3.41 E-05$ & V \\
\hline & $23050.31 c$ & $8.53 E-08$ & \\
\hline & $23051.31 \mathrm{C}$ & $3.40 E-05$ & \\
\hline C & $24000.21 \mathrm{C}$ & $1.46 \mathrm{E}-01$ & $U_{1}$ \\
\hline & $24050.21 c$ & $6.34 E-03$ & \\
\hline
\end{tabular}




\begin{tabular}{|c|c|c|c|}
\hline & $24052.21 \mathrm{C}$ & $1.22 \mathrm{E}-01$ & \\
\hline & $24053.21 \mathrm{C}$ & $1.39 E-02$ & \\
\hline & $24054.21 \mathrm{C}$ & $3.45 E-03$ & \\
\hline \multirow[t]{2}{*}{ C } & 25000 & $1.42 \mathrm{E}-02$ & $\mathrm{Mn}$ \\
\hline & $25055.21 \mathrm{C}$ & $1.42 \mathrm{E}-02$ & \\
\hline \multirow[t]{5}{*}{ C } & $26000.21 \mathrm{c}$ & $5.03 E-01$ & $\mathrm{Fe}$ \\
\hline & $26054.21 \mathrm{C}$ & $2.94 \mathrm{E}-02$ & \\
\hline & $26056.21 \mathrm{C}$ & $4.62 \mathrm{E}-01$ & \\
\hline & $26057.21 \mathrm{c}$ & $1.07 \mathrm{E}-02$ & \\
\hline & $26058.21 \mathrm{C}$ & $1.42 \mathrm{E}-03$ & \\
\hline \multirow[t]{2}{*}{ C } & $27000.21 \mathrm{C}$ & $3.68 E-04$ & $\mathrm{Co}$ \\
\hline & $27059.21 \mathrm{C}$ & $3.68 \mathrm{E}-04$ & \\
\hline \multirow[t]{6}{*}{ C } & $28000.21 \mathrm{c}$ & $9.06 \mathrm{E}-02$ & $\mathrm{Ni}$ \\
\hline & $28058.21 \mathrm{C}$ & $6.17 E-02$ & \\
\hline & $28060.21 \mathrm{c}$ & $2.38 E-02$ & \\
\hline & $28061.21 \mathrm{c}$ & $1.03 E-03$ & \\
\hline & $28062.21 \mathrm{C}$ & $3.29 E-03$ & \\
\hline & $28064.21 \mathrm{C}$ & $8.39 E-04$ & \\
\hline \multirow[t]{3}{*}{ C } & $29000.21 \mathrm{C}$ & $2.05 E-03$ & $\mathrm{Cu}$ \\
\hline & $29063.21 \mathrm{C}$ & 1. $42 E-03$ & \\
\hline & $29065.21 \mathrm{C}$ & $6.32 E-04$ & \\
\hline \multirow[t]{6}{*}{ C } & $40000.21 \mathrm{C}$ & $9.52 \mathrm{E}-06$ & Zr \\
\hline & $40090.31 \mathrm{C}$ & $4.90 \mathrm{E}-06$ & \\
\hline & $40091.31 \mathrm{C}$ & $1.07 E-06$ & \\
\hline & $40092.31 \mathrm{C}$ & $1.63 E-06$ & \\
\hline & $40094.31 \mathrm{C}$ & $1.65 \mathrm{E}-06$ & \\
\hline & $40096.31 \mathrm{C}$ & $2.67 E-07$ & \\
\hline \multirow[t]{2}{*}{ C } & 41000 & $4.67 E-05$ & $\mathrm{Nb}$ \\
\hline & $41093.21 \mathrm{C}$ & $4.67 E-05$ & \\
\hline \multirow[t]{8}{*}{$C$} & $42000.21 \mathrm{C}$ & $1.13 E-02$ & Mo \\
\hline & $42092.21 \mathrm{C}$ & $1.64 \mathrm{E}-03$ & \\
\hline & $42094.21 \mathrm{C}$ & $1.03 E-03$ & \\
\hline & $42095.21 \mathrm{C}$ & $1.79 E-03$ & \\
\hline & $42096.21 c$ & $1.88 \mathrm{E}-03$ & \\
\hline & $42097.21 \mathrm{C}$ & $1.08 E-03$ & \\
\hline & $42098.21 c$ & $2.76 \mathrm{E}-03$ & \\
\hline & $42100.21 \mathrm{C}$ & $1.11 E-03$ & \\
\hline \multirow[t]{11}{*}{ C } & $50000.21 \mathrm{C}$ & $7.31 \mathrm{E}-06$ & $\mathrm{Sn}$ \\
\hline & $50112.31 \mathrm{C}$ & $7.09 E-08$ & \\
\hline & $50114.31 \mathrm{C}$ & $4.82 \mathrm{E}-08$ & \\
\hline & $50115.31 \mathrm{C}$ & $2.49 \mathrm{E}-08$ & \\
\hline & $50116.31 \mathrm{C}$ & $1.06 E-06$ & \\
\hline & $50117.31 \mathrm{C}$ & $5.61 \mathrm{E}-07$ & \\
\hline & $50118.31 \mathrm{C}$ & $1.77 \mathrm{E}-06$ & \\
\hline & $50119.31 \mathrm{C}$ & $6.28 E-07$ & \\
\hline & $50120.31 \mathrm{C}$ & $2.38 E-06$ & \\
\hline & $50122.31 \mathrm{C}$ & $3.38 E-07$ & \\
\hline & $50124.31 \mathrm{C}$ & $4.23 E-07$ & \\
\hline \multirow[t]{2}{*}{ C } & $73000.21 c$ & $2.40 \mathrm{E}-05$ & $\mathrm{~T}$ \\
\hline & $73181.21 \mathrm{C}$ & $2.40 E-05$ & \\
\hline C & $74000.21 \mathrm{C}$ & $2.36 E-06$ & $\mathrm{~W}$ \\
\hline & $74180.31 \mathrm{C} 2$ & $2.83 \mathrm{E}-09$ & \\
\hline
\end{tabular}




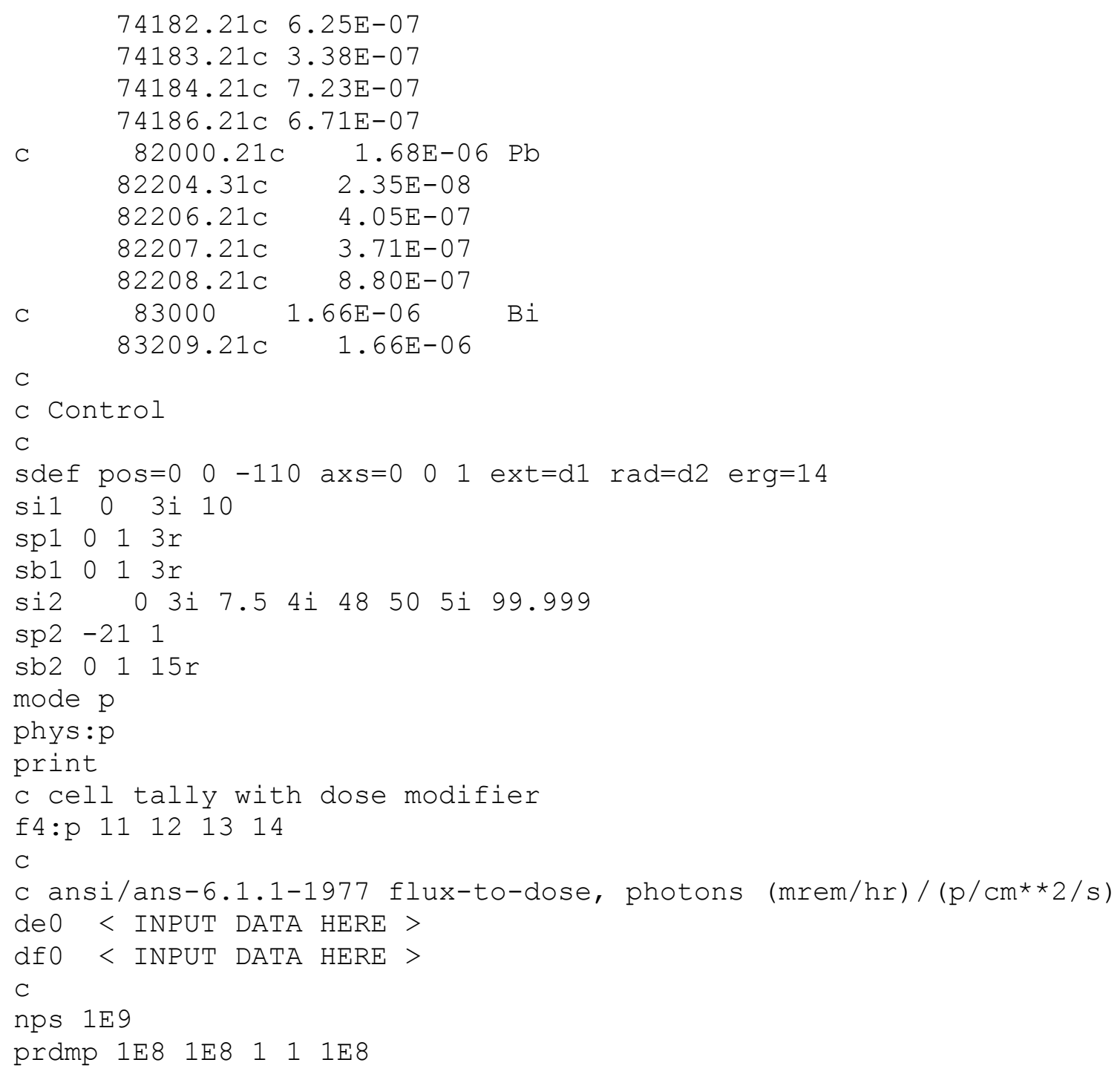




\section{menp_inp_N}

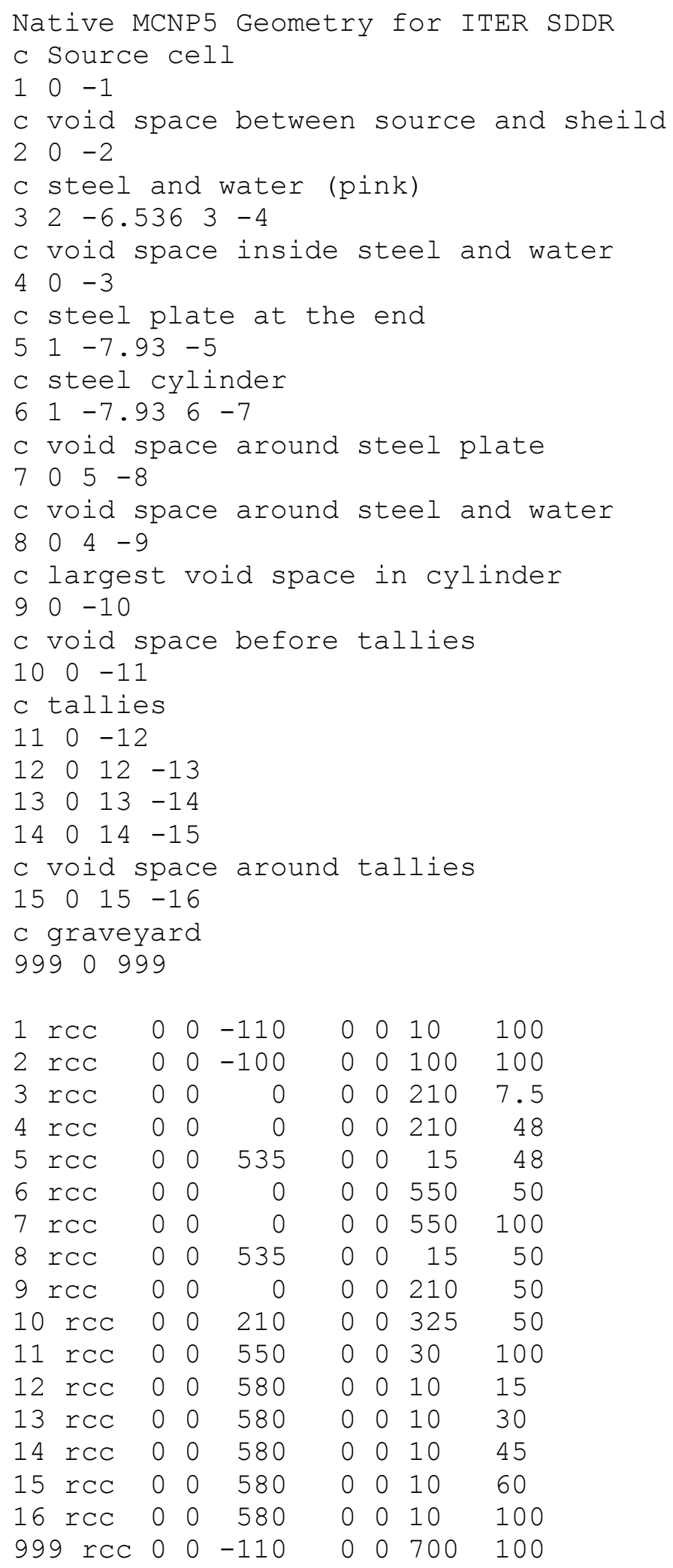




\begin{tabular}{|c|c|c|c|}
\hline \multicolumn{4}{|c|}{ c Imps } \\
\hline & $114 r 0$ & & \\
\hline & $114 r 0$ & & \\
\hline \\
\hline \\
\hline \multicolumn{4}{|c|}{ Materials } \\
\hline \\
\hline \multicolumn{4}{|c|}{ c steel } \\
\hline \multicolumn{4}{|c|}{ 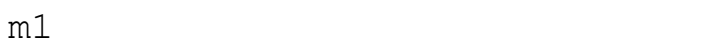 } \\
\hline \multirow[t]{3}{*}{$C$} & 5000 & $5.14 \mathrm{E}-05$ & B \\
\hline & $5010.21 c$ & $1.02 \mathrm{E}-05$ & \\
\hline & $5011.21 \mathrm{C}$ & $4.12 \mathrm{E}-05$ & \\
\hline \multirow[t]{2}{*}{ C } & $6000.21 c$ & $1.04 \mathrm{E}-03$ & $\mathrm{C}$ \\
\hline & $6012.21 c$ & $1.04 \mathrm{E}-03$ & \\
\hline \multirow[t]{3}{*}{ C } & 7000 & $2.78 E-03$ & $\mathrm{~N}$ \\
\hline & $7014.21 \mathrm{C}$ & $2.77 E-03$ & \\
\hline & $7015.21 \mathrm{C}$ & $1.01 \mathrm{E}-05$ & \\
\hline \multirow[t]{2}{*}{ C } & 8000 & $6.95 E-05$ & $\mathrm{O}$ \\
\hline & $8016.21 c$ & $6.95 \mathrm{E}-05$ & \\
\hline \multirow[t]{2}{*}{ C } & 13000 & $1.03 E-03$ & $\mathrm{Al}$ \\
\hline & $13027.21 c$ & $1.03 E-03$ & \\
\hline \multirow[t]{4}{*}{ C } & $14000.21 c$ & $9.89 E-03$ & $\mathrm{Si}$ \\
\hline & $14028.21 \mathrm{C}$ & $9.12 E-03$ & \\
\hline & $14029.21 \mathrm{C}$ & $4.63 E-04$ & \\
\hline & $14030.21 \mathrm{C}$ & $3.06 E-04$ & \\
\hline \multirow[t]{2}{*}{ C } & 15000 & $4.48 E-04$ & $\mathrm{P}$ \\
\hline & $15031.21 \mathrm{C}$ & $4.48 E-04$ & \\
\hline \multirow[t]{5}{*}{ C } & $16000.21 \mathrm{c}$ & $1.30 \mathrm{E}-04$ & S \\
\hline & $16032.31 \mathrm{C}$ & $1.23 E-04$ & \\
\hline & $16033.31 \mathrm{c}$ & $9.75 E-07$ & \\
\hline & $16034.31 \mathrm{C}$ & $5.53 E-06$ & \\
\hline & $16036.31 \mathrm{C}$ & $1.30 E-08$ & \\
\hline \multirow[t]{4}{*}{ C } & $19000.21 c$ & C $\quad 7.10 E-06$ & K \\
\hline & $19039.31 \mathrm{C}$ & $6.62 E-06$ & \\
\hline & $19040.31 \mathrm{c}$ & $8.31 E-10$ & \\
\hline & $19041.31 \mathrm{C}$ & $4.78 \mathrm{E}-07$ & \\
\hline \multirow[t]{6}{*}{ C } & $22000.21 c$ & C $1.74 E-03$ & $\mathrm{Ti}$ \\
\hline & $22046.21 c$ & $1.44 \mathrm{E}-04$ & \\
\hline & $22047.21 \mathrm{C}$ & 1.29E-04 & \\
\hline & $22048.21 \mathrm{c}$ & $1.28 \mathrm{E}-03$ & \\
\hline & $22049.21 \mathrm{C}$ & $9.41 E-05$ & \\
\hline & $22050.21 \mathrm{C}$ & $9.01 \mathrm{E}-05$ & \\
\hline \multirow[t]{3}{*}{ C } & $23000.21 c$ & $C 4.36 E-05$ & V \\
\hline & $23050.31 c$ & $1.09 \mathrm{E}-07$ & \\
\hline & $23051.31 \mathrm{c}$ & $4.35 E-05$ & \\
\hline \multirow[t]{5}{*}{ C } & $24000.21 c$ & C $\quad 1.87 \mathrm{E}-01$ & $\mathrm{Cr}$ \\
\hline & $24050.21 \mathrm{C}$ & $8.13 E-03$ & \\
\hline & $24052.21 \mathrm{c}$ & $1.57 \mathrm{E}-01$ & \\
\hline & $24053.21 \mathrm{c}$ & $1.78 \mathrm{E}-02$ & \\
\hline & $24054.21 \mathrm{C}$ & $4.42 E-03$ & \\
\hline \multirow[t]{2}{*}{ C } & 25000 & $1.82 \mathrm{E}-02$ & $\mathrm{Mn}$ \\
\hline & $25055.21 \mathrm{C}$ & $1.82 \mathrm{E}-02$ & \\
\hline
\end{tabular}




\begin{tabular}{|c|c|c|c|}
\hline$C$ & $26000.21 c$ & $6.44 \mathrm{E}-01$ & $\mathrm{Fe}$ \\
\hline & $26054.21 \mathrm{c}$ & $3.76 \mathrm{E}-02$ & \\
\hline & $26056.21 \mathrm{c}$ & $5.91 \mathrm{E}-01$ & \\
\hline & $26057.21 \mathrm{C}$ & $1.36 \mathrm{E}-02$ & \\
\hline & $26058.21 \mathrm{c}$ & $1.82 \mathrm{E}-03$ & \\
\hline & 27000 & $4.71 \mathrm{E}-04$ & $\mathrm{Co}$ \\
\hline & $27059.21 \mathrm{c}$ & $4.71 \mathrm{E}-04$ & \\
\hline & $28000.21 \mathrm{c}$ & $1.16 \mathrm{E}-01$ & $\mathrm{Ni}$ \\
\hline & $28058.21 c$ & $7.90 \mathrm{E}-02$ & \\
\hline & $28060.21 \mathrm{c}$ & $3.04 E-02$ & \\
\hline & $28061.21 \mathrm{C}$ & 1. $32 \mathrm{E}-03$ & \\
\hline & $28062.21 \mathrm{c}$ & $4.22 E-03$ & \\
\hline & $28064.21 \mathrm{c}$ & $1.07 E-03$ & \\
\hline & $29000.21 c$ & $2.62 E-03$ & $\mathrm{Cu}$ \\
\hline & $29063.21 \mathrm{C}$ & $1.81 E-03$ & \\
\hline & $29065.21 \mathrm{C}$ & $8.08 \mathrm{E}-04$ & \\
\hline & $40000.21 \mathrm{c}$ & $1.22 \mathrm{E}-05$ & Zr \\
\hline & $40090.31 \mathrm{C}$ & $6.28 \mathrm{E}-06$ & \\
\hline & $40091.31 \mathrm{C}$ & $1.37 E-06$ & \\
\hline & $40092.31 \mathrm{C}$ & $2.09 \mathrm{E}-06$ & \\
\hline & $40094.31 \mathrm{C}$ & $2.12 E-06$ & \\
\hline & $40096.31 \mathrm{C}$ & $3.42 E-07$ & \\
\hline & 41000 & $5.98 \mathrm{E}-05$ & $\mathrm{Nb}$ \\
\hline & $41093.21 \mathrm{C}$ & $5.98 \mathrm{E}-05$ & \\
\hline & $42000.21 c$ & 1. $45 E-02$ & Mo \\
\hline & $42092.21 \mathrm{C}$ & $2.11 E-03$ & \\
\hline & $42094.21 \mathrm{C}$ & $1.33 \mathrm{E}-03$ & \\
\hline & $42095.21 \mathrm{c}$ & $2.30 \mathrm{E}-03$ & \\
\hline & $42096.21 \mathrm{C}$ & $2.42 E-03$ & \\
\hline & $42097.21 \mathrm{C}$ & $1.39 \mathrm{E}-03$ & \\
\hline & $42098.21 \mathrm{C}$ & $3.54 \mathrm{E}-03$ & \\
\hline & $42100.21 \mathrm{C}$ & $1.42 \mathrm{E}-03$ & \\
\hline & $50000.21 c$ & $9.36 \mathrm{E}-06$ & $\mathrm{Sn}$ \\
\hline & $50112.31 c$ & $9.08 \mathrm{E}-08$ & \\
\hline & $50114.31 \mathrm{c}$ & $6.18 \mathrm{E}-08$ & \\
\hline & $50115.31 \mathrm{c}$ & $3.18 \mathrm{E}-08$ & \\
\hline & $50116.31 \mathrm{c}$ & $1.36 \mathrm{E}-06$ & \\
\hline & $50117.31 \mathrm{c}$ & $7.19 \mathrm{E}-07$ & \\
\hline & $50118.31 \mathrm{C}$ & $2.27 E-06$ & \\
\hline & $50119.31 \mathrm{c}$ & $8.04 \mathrm{E}-07$ & \\
\hline & $50120.31 c$ & $3.05 E-06$ & \\
\hline & $50122.31 c$ & $4.33 \mathrm{E}-07$ & \\
\hline & $50124.31 \mathrm{C}$ & $5.42 \mathrm{E}-07$ & \\
\hline & $73000.21 c$ & $3.07 E-05$ & $\mathrm{Ta}$ \\
\hline & $73181.21 \mathrm{C}$ & $3.07 E-05$ & \\
\hline & $74000.21 \mathrm{c}$ & $3.02 E-06$ & W \\
\hline & $74180.31 \mathrm{C}$ & $3.62 E-09$ & \\
\hline & $74182.21 \mathrm{C}$ & $8.00 \mathrm{E}-07$ & \\
\hline & $74183.21 \mathrm{C}$ & $4.32 E-07$ & \\
\hline & $74184.21 \mathrm{C}$ & $9.25 E-07$ & \\
\hline & $74186.21 c$ & $8.59 \mathrm{E}-07$ & \\
\hline & $0.21 c$ & $=\quad 2.14 \mathrm{E}-06$ & \\
\hline
\end{tabular}




\begin{tabular}{|c|c|c|c|}
\hline & & & \\
\hline & & $3.00 \mathrm{E}-08$ & \\
\hline & $82206.21 c$ & $5.16 \mathrm{E}-07$ & \\
\hline & $82207.21 \mathrm{C}$ & $4.73 E-07$ & \\
\hline & $82208.21 \mathrm{C}$ & $1.12 \mathrm{E}-06$ & \\
\hline C & 83000 & $2.13 E-06$ & $\mathrm{Bi}$ \\
\hline & $83209.21 \mathrm{C}$ & $2.13 E-06$ & \\
\hline C & & & \\
\hline C & & & \\
\hline C & & & \\
\hline & el and wate & & \\
\hline m2 & & & \\
\hline C & 1000 & $1.46 \mathrm{E}-01$ & $\mathrm{H}$ \\
\hline & $1001.21 c$ & $1.46 \mathrm{E}-01$ & \\
\hline & $1002.21 c$ & $1.68 \mathrm{E}-05$ & \\
\hline C & 5000 & $4.02 E-05$ & B \\
\hline & $5010.21 c$ & $8.00 E-06$ & \\
\hline & $5011.21 c$ & $3.22 \mathrm{E}-05$ & \\
\hline C & $6000.21 \mathrm{c}$ & $8.14 \mathrm{E}-04$ & $\mathrm{C}$ \\
\hline & $6012.21 c$ & $8.14 \mathrm{E}-04$ & \\
\hline C & 7000 & $2.17 E-03$ & $\mathrm{~N}$ \\
\hline & $7014.21 c$ & $2.16 \mathrm{E}-03$ & \\
\hline & $7015.21 c$ & $7.90 \mathrm{E}-06$ & \\
\hline C & 8000 & $7.29 E-02$ & 0 \\
\hline & $8016.21 c$ & $7.29 \mathrm{E}-02$ & \\
\hline C & 13000 & $8.04 \mathrm{E}-04$ & Al \\
\hline & $13027.21 \mathrm{C}$ & $8.04 \mathrm{E}-04$ & \\
\hline C & $14000.21 \mathrm{C}$ & $7.73 E-03$ & $\mathrm{Si}$ \\
\hline & $14028.21 \mathrm{C}$ & $7.13 E-03$ & \\
\hline & $14029.21 \mathrm{C}$ & $3.62 \mathrm{E}-04$ & \\
\hline & $14030.21 \mathrm{C}$ & $2.39 E-04$ & \\
\hline C & 15000 & $3.50 \mathrm{E}-04$ & $\mathrm{P}$ \\
\hline & $15031.21 \mathrm{C}$ & $3.50 \mathrm{E}-04$ & \\
\hline C & $16000.21 \mathrm{c}$ & $1.02 E-04$ & S \\
\hline & $16032.31 \mathrm{C}$ & $9.69 \mathrm{E}-05$ & \\
\hline & $16033.31 \mathrm{c}$ & $7.65 E-07$ & \\
\hline & $16034.31 \mathrm{c}$ & $4.34 E-06$ & \\
\hline & $16036.31 \mathrm{c}$ & $1.02 \mathrm{E}-08$ & \\
\hline C & $19000.21 \mathrm{C}$ & $5.55 \mathrm{E}-06$ & K \\
\hline & $19039.31 \mathrm{C}$ & $5.18 \mathrm{E}-06$ & \\
\hline & $19040.31 \mathrm{C}$ & $6.49 \mathrm{E}-10$ & \\
\hline & $19041.31 \mathrm{C}$ & $3.74 \mathrm{E}-07$ & \\
\hline C & $22000.21 \mathrm{C}$ & $1.36 \mathrm{E}-03$ & $\mathrm{Ti}$ \\
\hline & $22046.21 \mathrm{C}$ & $1.12 \mathrm{E}-04$ & \\
\hline & $22047.21 \mathrm{C}$ & $1.01 \mathrm{E}-04$ & \\
\hline & $22048.21 c$ & $1.00 \mathrm{E}-03$ & \\
\hline & $22049.21 \mathrm{C}$ & $7.36 \mathrm{E}-05$ & \\
\hline & $22050.21 \mathrm{C}$ & $7.04 \mathrm{E}-05$ & \\
\hline C & $23000.21 \mathrm{C}$ & $3.41 E-05$ & V \\
\hline & $23050.31 c$ & $8.53 E-08$ & \\
\hline & $23051.31 \mathrm{C}$ & $3.40 E-05$ & \\
\hline C & $24000.21 \mathrm{C}$ & $1.46 \mathrm{E}-01$ & $U_{1}$ \\
\hline & $24050.21 c$ & $6.34 E-03$ & \\
\hline
\end{tabular}




\begin{tabular}{|c|c|c|c|}
\hline & $24052.21 \mathrm{C}$ & $1.22 \mathrm{E}-01$ & \\
\hline & $24053.21 \mathrm{C}$ & $1.39 E-02$ & \\
\hline & $24054.21 \mathrm{C}$ & $3.45 E-03$ & \\
\hline \multirow[t]{2}{*}{ C } & 25000 & $1.42 \mathrm{E}-02$ & $\mathrm{Mn}$ \\
\hline & $25055.21 \mathrm{C}$ & $1.42 \mathrm{E}-02$ & \\
\hline \multirow[t]{5}{*}{ C } & $26000.21 \mathrm{c}$ & $5.03 E-01$ & $\mathrm{Fe}$ \\
\hline & $26054.21 \mathrm{C}$ & $2.94 \mathrm{E}-02$ & \\
\hline & $26056.21 \mathrm{C}$ & $4.62 \mathrm{E}-01$ & \\
\hline & $26057.21 \mathrm{c}$ & $1.07 \mathrm{E}-02$ & \\
\hline & $26058.21 \mathrm{C}$ & $1.42 \mathrm{E}-03$ & \\
\hline \multirow[t]{2}{*}{ C } & $27000.21 \mathrm{C}$ & $3.68 E-04$ & $\mathrm{Co}$ \\
\hline & $27059.21 \mathrm{C}$ & $3.68 \mathrm{E}-04$ & \\
\hline \multirow[t]{6}{*}{ C } & $28000.21 \mathrm{c}$ & $9.06 \mathrm{E}-02$ & $\mathrm{Ni}$ \\
\hline & $28058.21 \mathrm{C}$ & $6.17 E-02$ & \\
\hline & $28060.21 \mathrm{c}$ & $2.38 E-02$ & \\
\hline & $28061.21 \mathrm{c}$ & $1.03 E-03$ & \\
\hline & $28062.21 \mathrm{C}$ & $3.29 E-03$ & \\
\hline & $28064.21 \mathrm{C}$ & $8.39 E-04$ & \\
\hline \multirow[t]{3}{*}{ C } & $29000.21 \mathrm{C}$ & $2.05 E-03$ & $\mathrm{Cu}$ \\
\hline & $29063.21 \mathrm{C}$ & 1. $42 E-03$ & \\
\hline & $29065.21 \mathrm{C}$ & $6.32 E-04$ & \\
\hline \multirow[t]{6}{*}{ C } & $40000.21 \mathrm{C}$ & $9.52 \mathrm{E}-06$ & Zr \\
\hline & $40090.31 \mathrm{C}$ & $4.90 \mathrm{E}-06$ & \\
\hline & $40091.31 \mathrm{C}$ & $1.07 E-06$ & \\
\hline & $40092.31 \mathrm{C}$ & $1.63 E-06$ & \\
\hline & $40094.31 \mathrm{C}$ & $1.65 \mathrm{E}-06$ & \\
\hline & $40096.31 \mathrm{C}$ & $2.67 E-07$ & \\
\hline \multirow[t]{2}{*}{ C } & 41000 & $4.67 E-05$ & $\mathrm{Nb}$ \\
\hline & $41093.21 \mathrm{C}$ & $4.67 E-05$ & \\
\hline \multirow[t]{8}{*}{$C$} & $42000.21 \mathrm{C}$ & $1.13 E-02$ & Mo \\
\hline & $42092.21 \mathrm{C}$ & $1.64 \mathrm{E}-03$ & \\
\hline & $42094.21 \mathrm{C}$ & $1.03 E-03$ & \\
\hline & $42095.21 \mathrm{C}$ & $1.79 E-03$ & \\
\hline & $42096.21 c$ & $1.88 \mathrm{E}-03$ & \\
\hline & $42097.21 \mathrm{C}$ & $1.08 E-03$ & \\
\hline & $42098.21 c$ & $2.76 \mathrm{E}-03$ & \\
\hline & $42100.21 \mathrm{C}$ & $1.11 E-03$ & \\
\hline \multirow[t]{11}{*}{ C } & $50000.21 \mathrm{C}$ & $7.31 \mathrm{E}-06$ & $\mathrm{Sn}$ \\
\hline & $50112.31 \mathrm{C}$ & $7.09 E-08$ & \\
\hline & $50114.31 \mathrm{C}$ & $4.82 \mathrm{E}-08$ & \\
\hline & $50115.31 \mathrm{C}$ & $2.49 \mathrm{E}-08$ & \\
\hline & $50116.31 \mathrm{C}$ & $1.06 E-06$ & \\
\hline & $50117.31 \mathrm{C}$ & $5.61 \mathrm{E}-07$ & \\
\hline & $50118.31 \mathrm{C}$ & $1.77 \mathrm{E}-06$ & \\
\hline & $50119.31 \mathrm{C}$ & $6.28 E-07$ & \\
\hline & $50120.31 \mathrm{C}$ & $2.38 E-06$ & \\
\hline & $50122.31 \mathrm{C}$ & $3.38 E-07$ & \\
\hline & $50124.31 \mathrm{C}$ & $4.23 E-07$ & \\
\hline \multirow[t]{2}{*}{ C } & $73000.21 c$ & $2.40 \mathrm{E}-05$ & $\mathrm{~T}$ \\
\hline & $73181.21 \mathrm{C}$ & $2.40 E-05$ & \\
\hline C & $74000.21 \mathrm{C}$ & $2.36 E-06$ & $\mathrm{~W}$ \\
\hline & $74180.31 \mathrm{C} 2$ & $2.83 \mathrm{E}-09$ & \\
\hline
\end{tabular}




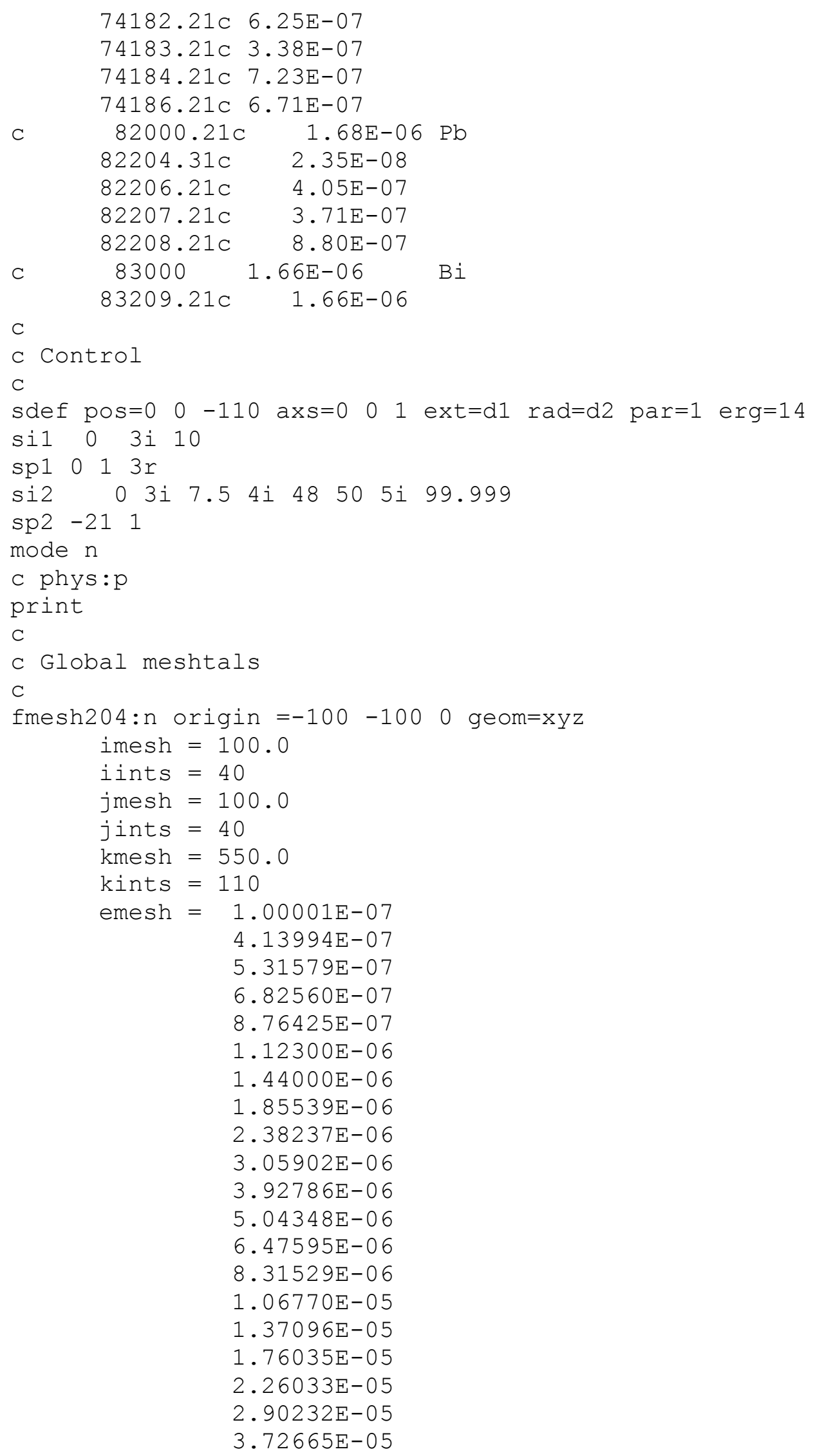


$4.78512 \mathrm{E}-05$

$6.14421 \mathrm{E}-05$

$7.88932 \mathrm{E}-05$

$1.01301 \mathrm{E}-04$

$1.30073 \mathrm{E}-04$

1. $67017 \mathrm{E}-04$

$2.14454 \mathrm{E}-04$

$2.75364 \mathrm{E}-04$

3. $53575 \mathrm{E}-04$

$4.53999 \mathrm{E}-04$

$5.82947 \mathrm{E}-04$

$7.48518 \mathrm{E}-04$

9. $61117 \mathrm{E}-04$

$1.23410 \mathrm{E}-03$

$1.58461 \mathrm{E}-03$

$2.03468 \mathrm{E}-03$

$2.24867 \mathrm{E}-03$

2. $48517 \mathrm{E}-03$

2. 61259E-03

$2.74654 \mathrm{E}-03$

$3.03539 \mathrm{E}-03$

3. $35463 \mathrm{E}-03$

3. $70744 \mathrm{E}-03$

$4.30742 \mathrm{E}-03$

$5.53084 \mathrm{E}-03$

$7.10174 \mathrm{E}-03$

$9.11882 \mathrm{E}-03$

$1.05946 \mathrm{E}-02$

$1.17088 \mathrm{E}-02$

1. $50344 \mathrm{E}-02$

1. $93045 \mathrm{E}-02$

$2.18749 \mathrm{E}-02$

2. $35786 \mathrm{E}-02$

2. $41755 \mathrm{E}-02$

$2.47875 \mathrm{E}-02$

$2.60584 \mathrm{E}-02$

$2.70001 \mathrm{E}-02$

$2.85011 \mathrm{E}-02$

$3.18278 \mathrm{E}-02$

3. $43067 \mathrm{E}-02$

$4.08677 \mathrm{E}-02$

4. $63092 \mathrm{E}-02$

$5.24752 \mathrm{E}-02$

$5.65622 \mathrm{E}-02$

$6.73795 \mathrm{E}-02$

$7.20245 \mathrm{E}-02$

$7.94987 \mathrm{E}-02$

$8.25034 \mathrm{E}-02$

$8.65170 \mathrm{E}-02$

$9.80365 \mathrm{E}-02$

$1.11090 \mathrm{E}-01$

$1.16786 \mathrm{E}-01$ 
$1.22773 \mathrm{E}-01$

1. $29068 \mathrm{E}-01$

1. $35686 \mathrm{E}-01$

1. $42642 \mathrm{E}-01$

$1.49956 \mathrm{E}-01$

$1.57644 \mathrm{E}-01$

$1.65727 \mathrm{E}-01$

1. $74224 \mathrm{E}-01$

$1.83156 \mathrm{E}-01$

1. $92547 \mathrm{E}-01$

2. $02419 \mathrm{E}-01$

$2.12797 \mathrm{E}-01$

$2.23708 \mathrm{E}-01$

2.35177E-01

$2.47235 \mathrm{E}-01$

$2.73237 \mathrm{E}-01$

2. $87246 \mathrm{E}-01$

2. $94518 \mathrm{E}-01$

2. $97211 \mathrm{E}-01$

2. $98491 \mathrm{E}-01$

3. $01974 \mathrm{E}-01$

3. $33733 \mathrm{E}-01$

3. $68832 \mathrm{E}-01$

3. $87742 \mathrm{E}-01$

$4.07622 \mathrm{E}-01$

4. $50492 \mathrm{E}-01$

4. $97871 \mathrm{E}-01$

$5.23397 \mathrm{E}-01$

$5.50232 \mathrm{E}-01$

$5.78443 \mathrm{E}-01$

$6.08101 \mathrm{E}-01$

$6.39279 \mathrm{E}-01$

$6.72055 \mathrm{E}-01$

$7.06512 \mathrm{E}-01$

$7.42736 \mathrm{E}-01$

7. $80817 \mathrm{E}-01$

$8.20850 \mathrm{E}-01$

$8.62936 \mathrm{E}-01$

$9.07180 \mathrm{E}-01$

9.61672E-01

$1.00259 \mathrm{E}+00$

$1.10803 \mathrm{E}+00$

$1.16484 \mathrm{E}+00$

1. $22456 \mathrm{E}+00$

$1.28735 \mathrm{E}+00$

$1.35335 \mathrm{E}+00$

1. $42274 \mathrm{E}+00$

$1.49569 \mathrm{E}+00$

$1.57237 \mathrm{E}+00$

1. $65299 \mathrm{E}+00$

$1.73774 \mathrm{E}+00$

1. $82684 \mathrm{E}+00$ 
1. $92050 \mathrm{E}+00$

$2.01897 \mathrm{E}+00$

$2.12248 \mathrm{E}+00$

2. $23130 \mathrm{E}+00$

2. $30693 \mathrm{E}+00$

$2.34570 \mathrm{E}+00$

2. $36533 \mathrm{E}+00$

$2.38513 \mathrm{E}+00$

$2.46597 \mathrm{E}+00$

2. $59240 \mathrm{E}+00$

$2.72532 \mathrm{E}+00$

$2.86505 \mathrm{E}+00$

3. $01194 \mathrm{E}+00$

$3.16637 \mathrm{E}+00$

3. $32871 \mathrm{E}+00$

3. $67879 \mathrm{E}+00$

$4.06570 \mathrm{E}+00$

$4.49329 \mathrm{E}+00$

$4.72367 \mathrm{E}+00$

$4.96585 \mathrm{E}+00$

$5.22046 \mathrm{E}+00$

$5.48812 \mathrm{E}+00$

$5.76950 \mathrm{E}+00$

$6.06531 \mathrm{E}+00$

$6.37628 \mathrm{E}+00$

$6.59241 \mathrm{E}+00$

$6.70320 \mathrm{E}+00$

$7.04688 \mathrm{E}+00$

$7.40818 \mathrm{E}+00$

$7.78801 \mathrm{E}+00$

$8.18731 \mathrm{E}+00$

$8.60708 \mathrm{E}+00$

9. $04837 \mathrm{E}+00$

$9.51229 \mathrm{E}+00$

$1.00000 \mathrm{E}+01$

$1.05127 \mathrm{E}+01$

$1.10517 \mathrm{E}+01$

$1.16183 \mathrm{E}+01$

1. $22140 \mathrm{E}+01$

1. $25232 \mathrm{E}+01$

$1.28403 \mathrm{E}+01$

1. $34986 \mathrm{E}+01$

1. $38403 \mathrm{E}+01$

$1.41907 \mathrm{E}+01$

$1.45499 \mathrm{E}+01$

$1.49182 \mathrm{E}+01$

$1.56831 \mathrm{E}+01$

$1.64872 \mathrm{E}+01$

$1.69046 \mathrm{E}+01$

$1.73325 \mathrm{E}+01$

1. $96403 \mathrm{E}+01$

C 
C

nps 1E7

prdmp 1E7 $1 \mathrm{E} 7 \quad 1 \quad 1 \quad$ 1E7

B-21 


\section{monp_inp_N_adv}

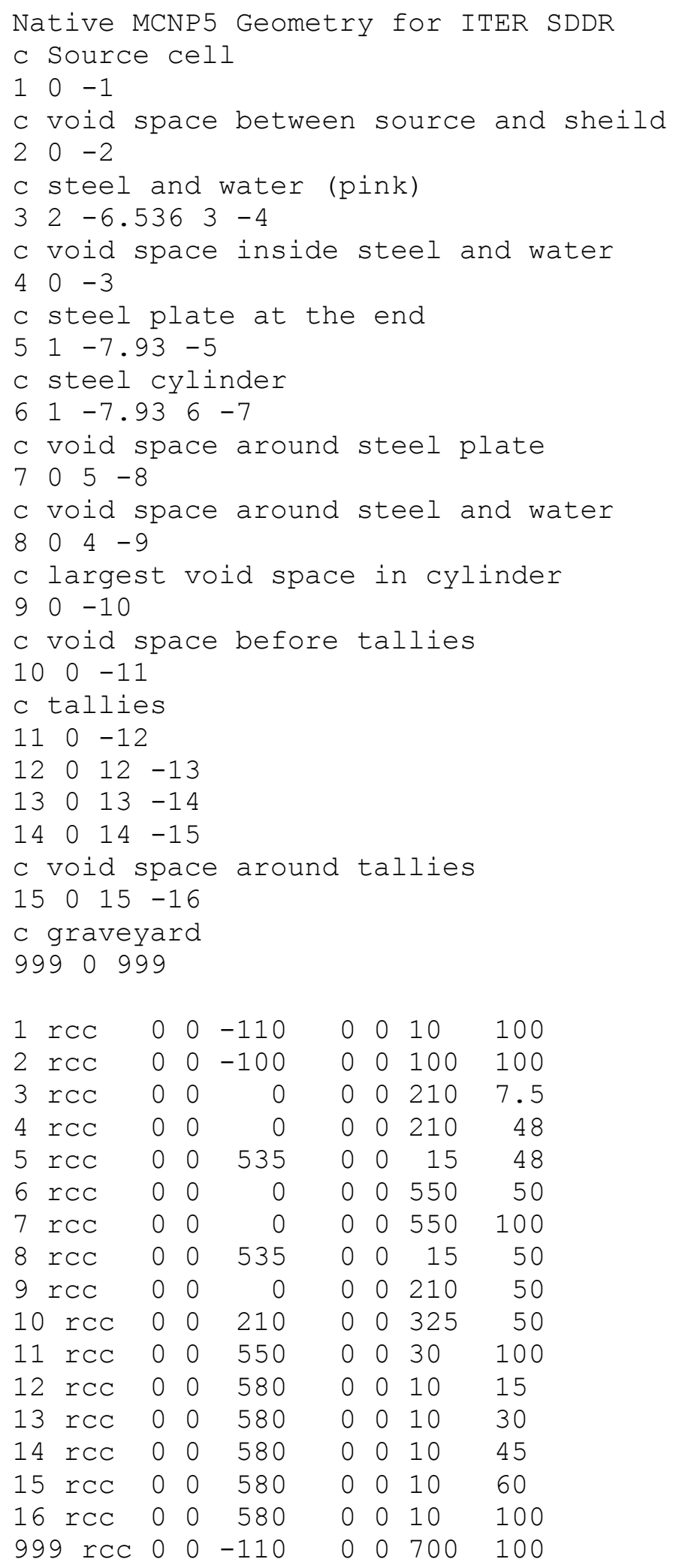




\begin{tabular}{|c|c|c|c|}
\hline \multicolumn{4}{|c|}{ c Imps } \\
\hline \multicolumn{4}{|c|}{$i m p: n \quad 1$ 14r 0} \\
\hline \multirow{2}{*}{\multicolumn{4}{|c|}{ imp:p 1 14r 0}} \\
\hline & & & \\
\hline \\
\hline \multirow{2}{*}{\multicolumn{4}{|c|}{ Materials }} \\
\hline & & & \\
\hline \multicolumn{4}{|c|}{ m1 } \\
\hline \multirow[t]{3}{*}{$\mathrm{C}$} & 5000 & $5.14 \mathrm{E}-05$ & B \\
\hline & $5010.21 \mathrm{C}$ & $1.02 \mathrm{E}-05$ & \\
\hline & $5011.21 \mathrm{C}$ & $4.12 \mathrm{E}-05$ & \\
\hline \multirow[t]{2}{*}{ C } & $6000.21 c$ & $1.04 E-03$ & $\mathrm{C}$ \\
\hline & $6012.21 c$ & $1.04 \mathrm{E}-03$ & \\
\hline \multirow[t]{3}{*}{ C } & 7000 & $2.78 E-03$ & $\mathrm{~N}$ \\
\hline & $7014.21 c$ & $2.77 \mathrm{E}-03$ & \\
\hline & $7015.21 c$ & $1.01 \mathrm{E}-05$ & \\
\hline \multirow[t]{2}{*}{ C } & 8000 & $6.95 E-05$ & 0 \\
\hline & $8016.21 \mathrm{C}$ & $6.95 \mathrm{E}-05$ & \\
\hline \multirow[t]{2}{*}{ C } & 13000 & $1.03 \mathrm{E}-03$ & $A 1$ \\
\hline & $13027.21 \mathrm{C}$ & $1.03 E-03$ & \\
\hline \multirow[t]{4}{*}{ C } & $14000.21 c$ & $9.89 \mathrm{E}-03$ & $\mathrm{Si}$ \\
\hline & $14028.21 \mathrm{C}$ & $9.12 \mathrm{E}-03$ & \\
\hline & $14029.21 \mathrm{C}$ & $4.63 E-04$ & \\
\hline & $14030.21 \mathrm{C}$ & $3.06 E-04$ & \\
\hline \multirow[t]{2}{*}{ C } & 15000 & $4.48 E-04$ & $\mathrm{P}$ \\
\hline & $15031.21 \mathrm{C}$ & 4. $48 E-04$ & \\
\hline \multirow[t]{5}{*}{ C } & $16000.21 \mathrm{C}$ & $1.30 E-04$ & S \\
\hline & $16032.31 c$ & $1.23 E-04$ & \\
\hline & $16033.31 \mathrm{c}$ & $9.75 E-07$ & \\
\hline & $16034.31 \mathrm{C}$ & $5.53 E-06$ & \\
\hline & $16036.31 \mathrm{C}$ & 1. $30 E-08$ & \\
\hline \multirow[t]{4}{*}{ C } & $19000.21 \mathrm{C}$ & $7.10 \mathrm{E}-06$ & K \\
\hline & $19039.31 \mathrm{C}$ & $6.62 E-06$ & \\
\hline & $19040.31 \mathrm{C}$ & $8.31 E-10$ & \\
\hline & $19041.31 \mathrm{C}$ & $4.78 \mathrm{E}-07$ & \\
\hline \multirow[t]{6}{*}{$\mathrm{C}$} & $22000.21 \mathrm{C}$ & C $1.74 \mathrm{E}-03$ & $\mathrm{Ti}$ \\
\hline & $22046.21 c$ & $1.44 \mathrm{E}-04$ & \\
\hline & $22047.21 c$ & $1.29 \mathrm{E}-04$ & \\
\hline & $22048.21 c$ & $1.28 \mathrm{E}-03$ & \\
\hline & $22049.21 c$ & $9.41 E-05$ & \\
\hline & $22050.21 c$ & $9.01 E-05$ & \\
\hline \multirow[t]{3}{*}{ C } & $23000.21 \mathrm{C}$ & $C 4.36 E-05$ & $\mathrm{~V}$ \\
\hline & $23050.31 c$ & $1.09 \mathrm{E}-07$ & \\
\hline & $23051.31 c$ & $4.35 E-05$ & \\
\hline C & $24000.21 \mathrm{C}$ & $1.87 \mathrm{E}-01$ & $\mathrm{Cr}$ \\
\hline & $24050.21 c$ & $8.13 \mathrm{E}-03$ & \\
\hline & $24052.21 c$ & $1.57 \mathrm{E}-01$ & \\
\hline & $24053.21 c$ & $1.78 \mathrm{E}-02$ & \\
\hline & $24054.21 c$ & $4.42 E-03$ & \\
\hline C & 25000 & $1.82 \mathrm{E}-02$ & $\mathrm{Mn}$ \\
\hline & $25055.21 c$ & 1. 82E-02 & \\
\hline
\end{tabular}




\begin{tabular}{|c|c|c|c|}
\hline$C$ & $26000.21 c$ & $6.44 \mathrm{E}-01$ & $\mathrm{Fe}$ \\
\hline & $26054.21 \mathrm{c}$ & $3.76 \mathrm{E}-02$ & \\
\hline & $26056.21 \mathrm{c}$ & $5.91 \mathrm{E}-01$ & \\
\hline & $26057.21 \mathrm{C}$ & $1.36 \mathrm{E}-02$ & \\
\hline & $26058.21 \mathrm{c}$ & $1.82 \mathrm{E}-03$ & \\
\hline & 27000 & $4.71 \mathrm{E}-04$ & $\mathrm{Co}$ \\
\hline & $27059.21 \mathrm{c}$ & $4.71 \mathrm{E}-04$ & \\
\hline & $28000.21 \mathrm{c}$ & $1.16 \mathrm{E}-01$ & $\mathrm{Ni}$ \\
\hline & $28058.21 c$ & $7.90 \mathrm{E}-02$ & \\
\hline & $28060.21 \mathrm{c}$ & $3.04 E-02$ & \\
\hline & $28061.21 \mathrm{C}$ & 1. $32 \mathrm{E}-03$ & \\
\hline & $28062.21 \mathrm{c}$ & $4.22 E-03$ & \\
\hline & $28064.21 \mathrm{c}$ & $1.07 E-03$ & \\
\hline & $29000.21 c$ & $2.62 E-03$ & $\mathrm{Cu}$ \\
\hline & $29063.21 \mathrm{C}$ & $1.81 E-03$ & \\
\hline & $29065.21 \mathrm{C}$ & $8.08 \mathrm{E}-04$ & \\
\hline & $40000.21 \mathrm{c}$ & $1.22 \mathrm{E}-05$ & Zr \\
\hline & $40090.31 \mathrm{C}$ & $6.28 \mathrm{E}-06$ & \\
\hline & $40091.31 \mathrm{C}$ & $1.37 E-06$ & \\
\hline & $40092.31 \mathrm{C}$ & $2.09 \mathrm{E}-06$ & \\
\hline & $40094.31 \mathrm{C}$ & $2.12 E-06$ & \\
\hline & $40096.31 \mathrm{C}$ & $3.42 E-07$ & \\
\hline & 41000 & $5.98 \mathrm{E}-05$ & $\mathrm{Nb}$ \\
\hline & $41093.21 \mathrm{C}$ & $5.98 \mathrm{E}-05$ & \\
\hline & $42000.21 c$ & 1. $45 E-02$ & Mo \\
\hline & $42092.21 \mathrm{C}$ & $2.11 E-03$ & \\
\hline & $42094.21 \mathrm{C}$ & $1.33 \mathrm{E}-03$ & \\
\hline & $42095.21 \mathrm{c}$ & $2.30 \mathrm{E}-03$ & \\
\hline & $42096.21 \mathrm{C}$ & $2.42 E-03$ & \\
\hline & $42097.21 \mathrm{C}$ & $1.39 \mathrm{E}-03$ & \\
\hline & $42098.21 \mathrm{C}$ & $3.54 \mathrm{E}-03$ & \\
\hline & $42100.21 \mathrm{C}$ & $1.42 \mathrm{E}-03$ & \\
\hline & $50000.21 c$ & $9.36 \mathrm{E}-06$ & $\mathrm{Sn}$ \\
\hline & $50112.31 c$ & $9.08 \mathrm{E}-08$ & \\
\hline & $50114.31 \mathrm{c}$ & $6.18 \mathrm{E}-08$ & \\
\hline & $50115.31 \mathrm{c}$ & $3.18 \mathrm{E}-08$ & \\
\hline & $50116.31 \mathrm{c}$ & $1.36 \mathrm{E}-06$ & \\
\hline & $50117.31 \mathrm{c}$ & $7.19 \mathrm{E}-07$ & \\
\hline & $50118.31 \mathrm{C}$ & $2.27 E-06$ & \\
\hline & $50119.31 \mathrm{c}$ & $8.04 \mathrm{E}-07$ & \\
\hline & $50120.31 c$ & $3.05 E-06$ & \\
\hline & $50122.31 c$ & $4.33 \mathrm{E}-07$ & \\
\hline & $50124.31 \mathrm{C}$ & $5.42 \mathrm{E}-07$ & \\
\hline & $73000.21 c$ & $3.07 E-05$ & $\mathrm{Ta}$ \\
\hline & $73181.21 \mathrm{C}$ & $3.07 E-05$ & \\
\hline & $74000.21 \mathrm{c}$ & $3.02 E-06$ & W \\
\hline & $74180.31 \mathrm{C}$ & $3.62 E-09$ & \\
\hline & $74182.21 \mathrm{C}$ & $8.00 \mathrm{E}-07$ & \\
\hline & $74183.21 \mathrm{C}$ & $4.32 E-07$ & \\
\hline & $74184.21 \mathrm{C}$ & $9.25 E-07$ & \\
\hline & $74186.21 c$ & $8.59 \mathrm{E}-07$ & \\
\hline & $0.21 c$ & $=\quad 2.14 \mathrm{E}-06$ & \\
\hline
\end{tabular}




\begin{tabular}{|c|c|c|c|}
\hline & & & \\
\hline & & $3.00 \mathrm{E}-08$ & \\
\hline & $82206.21 c$ & $5.16 \mathrm{E}-07$ & \\
\hline & $82207.21 \mathrm{C}$ & $4.73 E-07$ & \\
\hline & $82208.21 \mathrm{C}$ & $1.12 \mathrm{E}-06$ & \\
\hline C & 83000 & $2.13 E-06$ & $\mathrm{Bi}$ \\
\hline & $83209.21 \mathrm{C}$ & $2.13 E-06$ & \\
\hline C & & & \\
\hline C & & & \\
\hline C & & & \\
\hline & el and wate & & \\
\hline m2 & & & \\
\hline C & 1000 & $1.46 \mathrm{E}-01$ & $\mathrm{H}$ \\
\hline & $1001.21 c$ & $1.46 \mathrm{E}-01$ & \\
\hline & $1002.21 c$ & $1.68 \mathrm{E}-05$ & \\
\hline C & 5000 & $4.02 E-05$ & B \\
\hline & $5010.21 c$ & $8.00 E-06$ & \\
\hline & $5011.21 c$ & $3.22 \mathrm{E}-05$ & \\
\hline C & $6000.21 \mathrm{c}$ & $8.14 \mathrm{E}-04$ & $\mathrm{C}$ \\
\hline & $6012.21 c$ & $8.14 \mathrm{E}-04$ & \\
\hline C & 7000 & $2.17 E-03$ & $\mathrm{~N}$ \\
\hline & $7014.21 c$ & $2.16 \mathrm{E}-03$ & \\
\hline & $7015.21 c$ & $7.90 \mathrm{E}-06$ & \\
\hline C & 8000 & $7.29 E-02$ & 0 \\
\hline & $8016.21 c$ & $7.29 \mathrm{E}-02$ & \\
\hline C & 13000 & $8.04 \mathrm{E}-04$ & Al \\
\hline & $13027.21 \mathrm{C}$ & $8.04 \mathrm{E}-04$ & \\
\hline C & $14000.21 \mathrm{C}$ & $7.73 E-03$ & $\mathrm{Si}$ \\
\hline & $14028.21 \mathrm{C}$ & $7.13 E-03$ & \\
\hline & $14029.21 \mathrm{C}$ & $3.62 \mathrm{E}-04$ & \\
\hline & $14030.21 \mathrm{C}$ & $2.39 E-04$ & \\
\hline C & 15000 & $3.50 \mathrm{E}-04$ & $\mathrm{P}$ \\
\hline & $15031.21 \mathrm{C}$ & $3.50 \mathrm{E}-04$ & \\
\hline C & $16000.21 \mathrm{c}$ & $1.02 E-04$ & S \\
\hline & $16032.31 \mathrm{C}$ & $9.69 \mathrm{E}-05$ & \\
\hline & $16033.31 \mathrm{c}$ & $7.65 E-07$ & \\
\hline & $16034.31 \mathrm{c}$ & $4.34 E-06$ & \\
\hline & $16036.31 \mathrm{c}$ & $1.02 \mathrm{E}-08$ & \\
\hline C & $19000.21 \mathrm{C}$ & $5.55 \mathrm{E}-06$ & K \\
\hline & $19039.31 \mathrm{C}$ & $5.18 \mathrm{E}-06$ & \\
\hline & $19040.31 \mathrm{C}$ & $6.49 \mathrm{E}-10$ & \\
\hline & $19041.31 \mathrm{C}$ & $3.74 \mathrm{E}-07$ & \\
\hline C & $22000.21 \mathrm{C}$ & $1.36 \mathrm{E}-03$ & $\mathrm{Ti}$ \\
\hline & $22046.21 \mathrm{C}$ & $1.12 \mathrm{E}-04$ & \\
\hline & $22047.21 \mathrm{C}$ & $1.01 \mathrm{E}-04$ & \\
\hline & $22048.21 c$ & $1.00 \mathrm{E}-03$ & \\
\hline & $22049.21 \mathrm{C}$ & $7.36 \mathrm{E}-05$ & \\
\hline & $22050.21 \mathrm{C}$ & $7.04 \mathrm{E}-05$ & \\
\hline C & $23000.21 \mathrm{C}$ & $3.41 E-05$ & V \\
\hline & $23050.31 c$ & $8.53 E-08$ & \\
\hline & $23051.31 \mathrm{C}$ & $3.40 E-05$ & \\
\hline C & $24000.21 \mathrm{C}$ & $1.46 \mathrm{E}-01$ & $U_{1}$ \\
\hline & $24050.21 c$ & $6.34 E-03$ & \\
\hline
\end{tabular}




\begin{tabular}{|c|c|c|c|}
\hline & $24052.21 \mathrm{C}$ & $1.22 E-01$ & \\
\hline & $24053.21 \mathrm{C}$ & $1.39 \mathrm{E}-02$ & \\
\hline & $24054.21 \mathrm{C}$ & $3.45 E-03$ & \\
\hline \multirow[t]{2}{*}{$\mathrm{C}$} & 25000 & $1.42 E-02$ & $\mathrm{Mn}$ \\
\hline & $25055.21 \mathrm{C}$ & $1.42 \mathrm{E}-02$ & \\
\hline \multirow[t]{5}{*}{$\mathrm{C}$} & $26000.21 \mathrm{c}$ & $5.03 E-01$ & $\mathrm{Fe}$ \\
\hline & $26054.21 \mathrm{c}$ & $2.94 \mathrm{E}-02$ & \\
\hline & $26056.21 c$ & $4.62 E-01$ & \\
\hline & $26057.21 c$ & $1.07 \mathrm{E}-02$ & \\
\hline & $26058.21 c$ & $1.42 \mathrm{E}-03$ & \\
\hline \multirow[t]{2}{*}{ C } & $27000.21 \mathrm{C}$ & $3.68 E-04$ & Co \\
\hline & $27059.21 \mathrm{C}$ & $3.68 E-04$ & \\
\hline \multirow[t]{6}{*}{ C } & $28000.21 \mathrm{C}$ & $9.06 \mathrm{E}-02$ & $\mathrm{Ni}$ \\
\hline & $28058.21 \mathrm{C}$ & $6.17 \mathrm{E}-02$ & \\
\hline & $28060.21 \mathrm{c}$ & $2.38 \mathrm{E}-02$ & \\
\hline & $28061.21 \mathrm{C}$ & $1.03 E-03$ & \\
\hline & $28062.21 \mathrm{C}$ & $3.29 \mathrm{E}-03$ & \\
\hline & $28064.21 \mathrm{C}$ & $8.39 E-04$ & \\
\hline \multirow[t]{3}{*}{ C } & $29000.21 \mathrm{C}$ & $2.05 E-03$ & $\mathrm{Cu}$ \\
\hline & $29063.21 \mathrm{C}$ & 1. $42 E-03$ & \\
\hline & $29065.21 \mathrm{C}$ & $6.32 E-04$ & \\
\hline \multirow[t]{6}{*}{ C } & $40000.21 \mathrm{C}$ & $9.52 \mathrm{E}-06$ & Zr \\
\hline & $40090.31 \mathrm{C}$ & $4.90 E-06$ & \\
\hline & $40091.31 \mathrm{C}$ & $1.07 \mathrm{E}-06$ & \\
\hline & $40092.31 \mathrm{C}$ & $1.63 E-06$ & \\
\hline & $40094.31 \mathrm{C}$ & $1.65 E-06$ & \\
\hline & $40096.31 \mathrm{C}$ & $2.67 \mathrm{E}-07$ & \\
\hline \multirow[t]{2}{*}{ C } & 41000 & $4.67 E-05$ & $\mathrm{Nb}$ \\
\hline & $41093.21 \mathrm{C}$ & $4.67 E-05$ & \\
\hline \multirow[t]{8}{*}{ C } & $42000.21 \mathrm{C}$ & $1.13 E-02$ & Mo \\
\hline & $42092.21 \mathrm{C}$ & $1.64 \mathrm{E}-03$ & \\
\hline & $42094.21 \mathrm{C}$ & $1.03 E-03$ & \\
\hline & $42095.21 \mathrm{C}$ & $1.79 \mathrm{E}-03$ & \\
\hline & $42096.21 \mathrm{C}$ & $1.88 \mathrm{E}-03$ & \\
\hline & $42097.21 \mathrm{C}$ & $1.08 \mathrm{E}-03$ & \\
\hline & $42098.21 \mathrm{C}$ & $2.76 \mathrm{E}-03$ & \\
\hline & $42100.21 \mathrm{C}$ & $1.11 E-03$ & \\
\hline \multirow[t]{11}{*}{ C } & $50000.21 \mathrm{C}$ & $7.31 E-06$ & $\mathrm{Sn}$ \\
\hline & $50112.31 c$ & $7.09 E-08$ & \\
\hline & $50114.31 \mathrm{C}$ & $4.82 E-08$ & \\
\hline & $50115.31 \mathrm{C}$ & $2.49 E-08$ & \\
\hline & $50116.31 \mathrm{C}$ & $1.06 \mathrm{E}-06$ & \\
\hline & $50117.31 \mathrm{C}$ & $5.61 \mathrm{E}-07$ & \\
\hline & $50118.31 \mathrm{C}$ & $1.77 \mathrm{E}-06$ & \\
\hline & $50119.31 \mathrm{C}$ & $6.28 E-07$ & \\
\hline & $50120.31 \mathrm{C}$ & $2.38 \mathrm{E}-06$ & \\
\hline & $50122.31 \mathrm{C}$ & $3.38 E-07$ & \\
\hline & $50124.31 \mathrm{C}$ & $4.23 E-07$ & \\
\hline \multirow[t]{2}{*}{ C } & $73000.21 \mathrm{C}$ & $2.40 E-05$ & $\mathrm{~T}$ \\
\hline & $73181.21 \mathrm{C}$ & $2.40 E-05$ & \\
\hline C & $74000.21 \mathrm{C}$ & $2.36 E-06$ & $\mathrm{~W}$ \\
\hline & $74180.31 \mathrm{c}$ & $2.83 E-09$ & \\
\hline
\end{tabular}




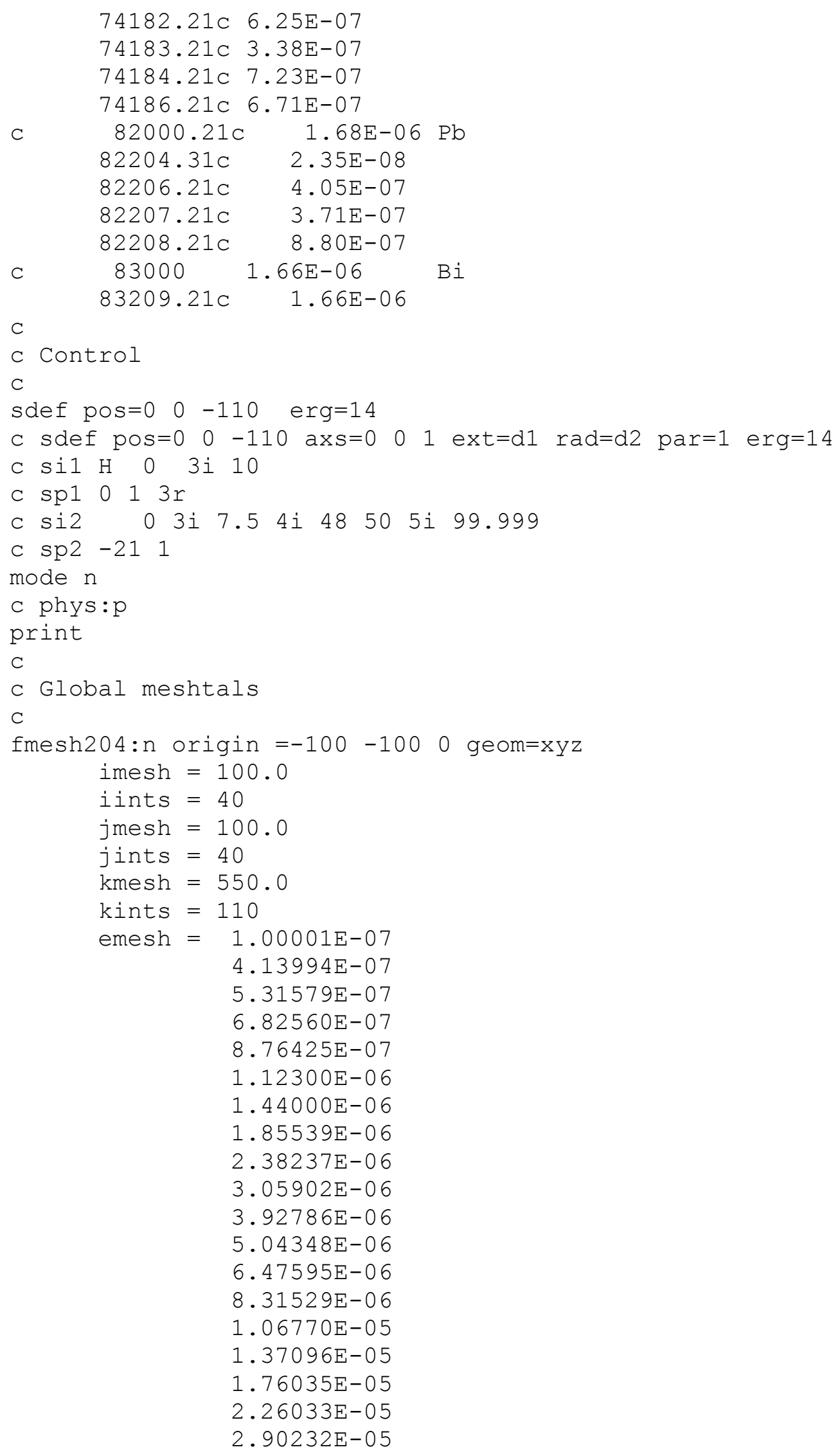


$3.72665 E-05$

$4.78512 \mathrm{E}-05$

$6.14421 \mathrm{E}-05$

$7.88932 \mathrm{E}-05$

$1.01301 \mathrm{E}-04$

$1.30073 \mathrm{E}-04$

1. $67017 \mathrm{E}-04$

$2.14454 \mathrm{E}-04$

$2.75364 \mathrm{E}-04$

3. $53575 \mathrm{E}-04$

$4.53999 \mathrm{E}-04$

$5.82947 \mathrm{E}-04$

$7.48518 \mathrm{E}-04$

9. 61117E-04

$1.23410 \mathrm{E}-03$

$1.58461 \mathrm{E}-03$

$2.03468 \mathrm{E}-03$

$2.24867 \mathrm{E}-03$

2. $48517 \mathrm{E}-03$

2. $61259 \mathrm{E}-03$

$2.74654 \mathrm{E}-03$

$3.03539 \mathrm{E}-03$

3. $35463 \mathrm{E}-03$

3. $70744 \mathrm{E}-03$

$4.30742 \mathrm{E}-03$

$5.53084 \mathrm{E}-03$

$7.10174 \mathrm{E}-03$

$9.11882 \mathrm{E}-03$

$1.05946 \mathrm{E}-02$

$1.17088 \mathrm{E}-02$

$1.50344 \mathrm{E}-02$

1. $93045 \mathrm{E}-02$

$2.18749 \mathrm{E}-02$

2.35786E-02

2. $41755 \mathrm{E}-02$

$2.47875 \mathrm{E}-02$

2. $60584 \mathrm{E}-02$

$2.70001 \mathrm{E}-02$

2. $85011 \mathrm{E}-02$

3.18278E-02

$3.43067 \mathrm{E}-02$

$4.08677 \mathrm{E}-02$

$4.63092 \mathrm{E}-02$

$5.24752 \mathrm{E}-02$

$5.65622 \mathrm{E}-02$

$6.73795 \mathrm{E}-02$

7.20245E-02

$7.94987 \mathrm{E}-02$

$8.25034 \mathrm{E}-02$

$8.65170 \mathrm{E}-02$

$9.80365 \mathrm{E}-02$

1. $11090 \mathrm{E}-01$ 
$1.16786 \mathrm{E}-01$

$1.22773 \mathrm{E}-01$

$1.29068 \mathrm{E}-01$

$1.35686 \mathrm{E}-01$

1. $42642 \mathrm{E}-01$

$1.49956 \mathrm{E}-01$

$1.57644 \mathrm{E}-01$

$1.65727 \mathrm{E}-01$

1. $74224 \mathrm{E}-01$

$1.83156 \mathrm{E}-01$

$1.92547 \mathrm{E}-01$

2. $02419 \mathrm{E}-01$

$2.12797 \mathrm{E}-01$

2. $23708 \mathrm{E}-01$

2. 35177 E-01

2. $47235 \mathrm{E}-01$

$2.73237 \mathrm{E}-01$

2. $87246 \mathrm{E}-01$

2. $94518 \mathrm{E}-01$

2. $97211 \mathrm{E}-01$

2. $98491 \mathrm{E}-01$

3. $01974 \mathrm{E}-01$

3. $33733 \mathrm{E}-01$

3. $68832 \mathrm{E}-01$

3. $87742 \mathrm{E}-01$

$4.07622 \mathrm{E}-01$

$4.50492 \mathrm{E}-01$

4. $97871 \mathrm{E}-01$

$5.23397 \mathrm{E}-01$

$5.50232 \mathrm{E}-01$

$5.78443 \mathrm{E}-01$

$6.08101 \mathrm{E}-01$

$6.39279 \mathrm{E}-01$

$6.72055 \mathrm{E}-01$

$7.06512 \mathrm{E}-01$

7. $42736 \mathrm{E}-01$

$7.80817 \mathrm{E}-01$

$8.20850 \mathrm{E}-01$

$8.62936 \mathrm{E}-01$

$9.07180 \mathrm{E}-01$

9.61672E-01

$1.00259 \mathrm{E}+00$

$1.10803 \mathrm{E}+00$

$1.16484 \mathrm{E}+00$

$1.22456 \mathrm{E}+00$

$1.28735 \mathrm{E}+00$

1. $35335 \mathrm{E}+00$

1. $42274 \mathrm{E}+00$

$1.49569 \mathrm{E}+00$

$1.57237 \mathrm{E}+00$

$1.65299 \mathrm{E}+00$

$1.73774 \mathrm{E}+00$ 
$1.82684 \mathrm{E}+00$

1. $92050 \mathrm{E}+00$

2. $01897 \mathrm{E}+00$

2. $12248 \mathrm{E}+00$

2. $23130 \mathrm{E}+00$

2. $30693 \mathrm{E}+00$

2. $34570 \mathrm{E}+00$

2. 36533E+00

2. $38513 \mathrm{E}+00$

$2.46597 \mathrm{E}+00$

$2.59240 \mathrm{E}+00$

$2.72532 \mathrm{E}+00$

2. $86505 \mathrm{E}+00$

3. $01194 \mathrm{E}+00$

$3.16637 \mathrm{E}+00$

3. $32871 \mathrm{E}+00$

3. $67879 \mathrm{E}+00$

$4.06570 \mathrm{E}+00$

$4.49329 \mathrm{E}+00$

$4.72367 \mathrm{E}+00$

$4.96585 \mathrm{E}+00$

$5.22046 \mathrm{E}+00$

$5.48812 \mathrm{E}+00$

$5.76950 \mathrm{E}+00$

$6.06531 \mathrm{E}+00$

$6.37628 \mathrm{E}+00$

$6.59241 \mathrm{E}+00$

$6.70320 \mathrm{E}+00$

$7.04688 \mathrm{E}+00$

$7.40818 \mathrm{E}+00$

$7.78801 \mathrm{E}+00$

$8.18731 \mathrm{E}+00$

$8.60708 \mathrm{E}+00$

$9.04837 \mathrm{E}+00$

$9.51229 \mathrm{E}+00$

$1.00000 \mathrm{E}+01$

$1.05127 \mathrm{E}+01$

$1.10517 \mathrm{E}+01$

$1.16183 \mathrm{E}+01$

$1.22140 \mathrm{E}+01$

1. $25232 \mathrm{E}+01$

$1.28403 \mathrm{E}+01$

1. $34986 \mathrm{E}+01$

1. $38403 \mathrm{E}+01$

$1.41907 \mathrm{E}+01$

$1.45499 \mathrm{E}+01$

$1.49182 \mathrm{E}+01$

$1.56831 \mathrm{E}+01$

$1.64872 \mathrm{E}+01$

$1.69046 \mathrm{E}+01$

$1.73325 \mathrm{E}+01$

$1.96403 \mathrm{E}+01$ 
C

nps 1 E 9

prdmp $1 \mathrm{E} 8 \quad 1 \mathrm{E} 8 \quad 1 \quad 1 \quad 1 \mathrm{E} 8$

B-31 


\section{config}

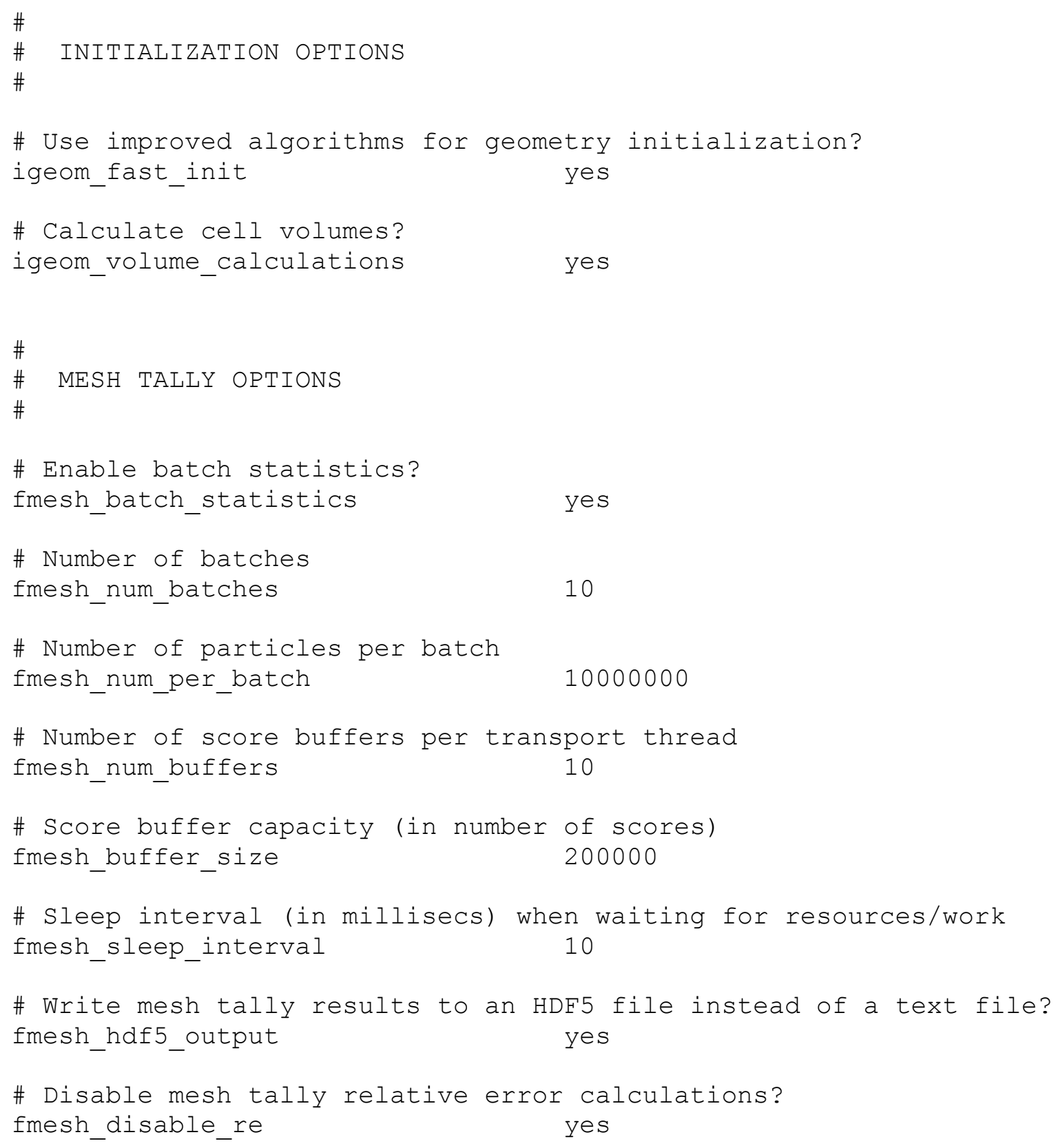




\section{config_G}

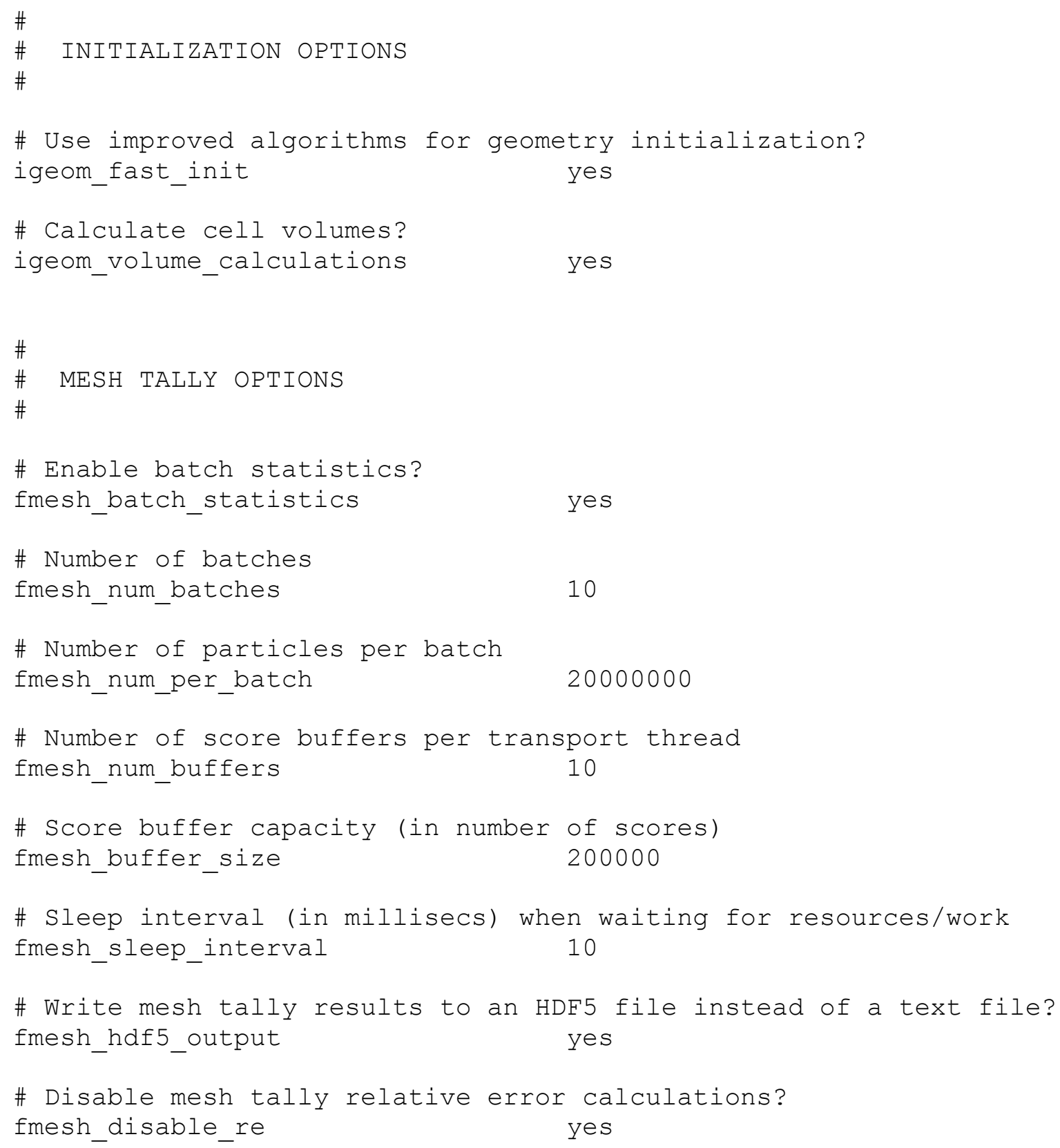

